\title{
Article
}

\section{Inhibitory Potential of New Phenolic Hydrazide-Hydrazones with a Decoy Substrate Fragment towards Laccase from a Phytopathogenic Fungus: SAR and Molecular Docking Studies}

\author{
Halina Maniak ${ }^{1, *\left(\mathbb{D}, \text { Michał Talma }^{2} \text { (D) and Mirosław Giurg }\right.}{ }^{3, *(\mathbb{D})}$ \\ 1 Department of Micro, Nano and Bioprocess Engineering, Faculty of Chemistry, \\ Wroclaw University of Science and Technology, Norwida 4/6, 50-373 Wrocław, Poland \\ 2 Department of Bioorganic Chemistry, Faculty of Chemistry, Wroclaw University of Science and Technology, \\ Wybrzeże Wyspiańskiego 27, 50-370 Wrocław, Poland; michal.talma@pwr.edu.pl \\ 3 Department of Organic and Medicinal Chemistry, Faculty of Chemistry, \\ Wroclaw University of Science and Technology, Wybrzeże Wyspiańskiego 27, 50-370 Wrocław, Poland \\ * Correspondence: halina.maniak@pwr.edu.pl (H.M.); miroslaw.giurg@pwr.edu.pl (M.G.); \\ Tel.: +48-713203314 (H.M.); +48-713203616 (M.G.)
}

\section{check for} updates

Citation: Maniak, H.; Talma, M.; Giurg, M. Inhibitory Potential of New Phenolic Hydrazide-Hydrazones with a Decoy Substrate Fragment towards Laccase from a Phytopathogenic Fungus: SAR and Molecular Docking Studies. Int. J. Mol. Sci. 2021, 22, 12307. https://doi.org/10.3390/ ijms222212307

Academic Editors: Dejan Stojković, Marija Ivanov and Ana Ćirić

Received: 29 October 2021

Accepted: 10 November 2021

Published: 14 November 2021

Publisher's Note: MDPI stays neutral with regard to jurisdictional claims in published maps and institutional affiliations.

Copyright: (c) 2021 by the authors. Licensee MDPI, Basel, Switzerland. This article is an open access article distributed under the terms and conditions of the Creative Commons Attribution (CC BY) license (https:// creativecommons.org/licenses/by/ $4.0 /)$
Abstract: Laccase from pathogenic fungi participates in both the delignification and neutralization of phytoantibiotics. Furthermore, it interferes with the hormone signaling in plants and catalyzes melanization. Infections of these pathogens contribute to loss in forestry, agriculture, and horticulture. As there is still a need to expand knowledge on efficient defense strategies against phytopathogenic fungi, the present study aimed to reveal more information on the molecular mechanisms of laccase inhibition with natural and natural-like carboxylic acid semi-synthetic derivatives. A set of hydrazidehydrazones derived from carboxylic acids, generally including electron-rich arene units that serve as a decoy substrate, was synthesized and tested with laccase from Trametes versicolor. The classic synthesis of the title inhibitors proceeded with good to almost quantitative yield. Ninety percent of the tested molecules were active in the range of $K_{\mathrm{I}}=8-233 \mu \mathrm{M}$ and showed different types of action. Such magnitude of inhibition constants qualified the hydrazide-hydrazones as strong laccase inhibitors. Molecular docking studies supporting the experimental data explained the selected derivatives' interactions with the enzyme. The results are promising in developing new potential antifungal agents mitigating the damage scale in the plant cultivation, gardening, and horticulture sectors.

Keywords: fungal oxidoreductase; electron-rich arene derivatives; enzyme kinetics; molecular modeling; structure-activity relationship

\section{Introduction}

Laccase (benzenediol: oxygen oxidoreductase, EC 1.10.3.2) is a blue multi-copper oxidase specific to a broad group of electron-rich arenes such as anilines and phenols. It has the exceptional ability to one electron oxidize both low- and high-molecular-weight substrates via direct or mediated reactions applied in green chemistry [1]. This nonspecific property has been reflected in numerous industrial, medical, and environmental applications [2-5]. Prokaryotes [6] and eukaryotes such as insects [7], plants, and fungi [8] produce laccase. Among the fungi, Ascomycota and Basidiomycota are well-known producers of this enzyme. Laccase participates in fungal metabolic pathways such as developing fruit bodies, the pigmentation of spores, and sexual differentiation [9]. It is also known as the virulence factor involved in the pathogenicity of humans [10-12] and plants [13-16]. Among the most troublesome filamentous fungi that produce laccase are Botrytis cinerea [17,18], Sclerotinia sclerotiorum [19], and Rhizoctonia sp. [20,21]. Furthermore, fungi parasitizing on trees use this enzyme in the degradation of lignin. Fungi release laccase into the plant tissues. It catalyzes lignin decomposition and neutralization of the auxins and phytoalexins, a primary barrier against pathogen attack. Such an infection strategy contributes to white-root 
of wood, crop, and ornamental plants diseases resulting in an enormous ecological and economic loss in forestry and agriculture [22,23].

Laccase inhibitors are a diversified group of organic and inorganic compounds [24]. To date, only a few examples of natural-derived compounds with inhibition potency towards laccase have been reported (Figure 1) [25-28]. These are hard-to-access medicarpin isolated from Dalbergia congestiflora Pittier heartwood [25], ptylomycalin A isolated from the marine sponge Monanchora arbuscula [26], and a mixture of humic acids with an undefined composition [27]. Another example is a semi-synthetic hydrazide-hydrazone, the derivative of coumarin and gentisaldehyde (2,5-dihydroxybenzaldehyde) [28]. Among them, the humic acids seem to be applicable as laccase inhibitors because of their environmental abundance. Nonetheless, the studies on laccase inhibition had only a preliminary character. Unfortunately, their applications have disadvantages because of the undefined chemical structure of the humic acid mixture [27] and their activity against a broad range of enzymes [29].<smiles>CCC1C=CCCC2(CC3CCC4C(C(=O)OCCCCCCC(=O)N(CCCN)CCCCN)C5(CCCC(C)O5)NC(=[N+]34)N2)O1</smiles><smiles>COc1ccc2c(c1)OC1c3ccc(O)cc3OCC21</smiles><smiles>Cc1cc(=O)oc2cc(OCC(=O)N/N=C/c3cc(O)ccc3O)ccc12</smiles>

Figure 1. Structures of laccase inhibitors: ptylomycalin A, medicarpin, and coumarin hydrazone.

Hydrazide-hydrazones are usually crystalline, easily available organic compounds. They may be synthesized in organic solvents [30] in the presence, or without, of acid additives with generally good to quantitative yields [31]. These are composed of carbonyl compounds linked by the hydrazine unit with carboxylic acid $\left(\mathrm{RR}^{\prime} \mathrm{C}=\mathrm{N}-\mathrm{NH}-(\mathrm{C}=\mathrm{O}) \mathrm{R}^{\prime \prime}\right)$ or sulfonic acids ( $\left.\mathrm{RR}^{\prime} \mathrm{C}=\mathrm{N}-\mathrm{NH}-\left(\mathrm{SO}_{2}\right) \mathrm{R}^{\prime \prime}\right)$ fragments [32]. They undergo easy dehydration to 1,3,4oxadiazoles that present a variety of biological activities [33,34]. Hydrazide-hydrazones provide interesting properties in the field of supramolecular architecture [35-39], organic synthesis [33,40], chemo- and physical imaging [41-44], coordination [45-49], and in inorganic chemistry [50-53]. The numerous biologically active hydrazide-hydrazones are particularly worth paying attention to [54]. Depending on the character of the present functional groups, these molecules are anticancer [43,55-58], antimicrobial [32,59-62], antiviral agents [63,64], and enzyme inhibitors [31,48,65-78]. Depending on the class of inhibited enzymes, the latter group may be further divided into monoamine oxidases $[67,71,79]$, lipid metabolism enzymes [74,75], and metalloenzyme inhibitors [31,65,66,68-70,77,78,80]. Nevertheless, knowledge about the hydrazide-hydrazones as inhibitors of metalloenzymes is still limited only to several studies reported in the literature so far. These compounds differ from the acyl unit, a heterocycle such as an imidazole, pyrazole, thiazole, or pyridyl derivatives, or an alkylated and/or electron-rich substituted benzene ring. There is no simple pattern that could link the activity of the hydrazide-hydrazones with metalloenzymes. In some cases, the hydrazide unit might act as a chelator agent of $\mathrm{O}$ and $\mathrm{N}$ coordination centers. Still, depending on the location of metal atoms in the protein, this mechanism 
must be carefully considered. The benzylidene unit is more diversified, but generally, the most common substituents are $\mathrm{OH}, \mathrm{OCH}_{3}, \mathrm{CH}_{3}$, or halogen $[31,65,66,68-70,77,78,80]$. The salicylidene unit is common in tested metalloenzyme inhibitors. Furthermore, there are only two examples in which the hydroxy group is localized in the benzene ring of the acyl unit. An example is a 3,4-dihydroxybenzoic acid [80], a catechol, and a well-known laccase substrate [81-83]. The next examples are the derivatives of 3- or 4-monohydroxybenzoic acid, both described in our previous work. We investigated the role of the benzylidene unit of hydrazide-hydrazones in laccase inhibition [31]. We showed that the 4-hydroxybenzoyl fragment derived from 4-hydroxybenzoic acid (4-HBA) constitutes a specific decoy being the mediator of reactions catalyzed by laccase [84]. However, the units from salicylic aldehydes are also responsible for specific interaction with amino acids in the substrate cavity of the enzyme. These results showed that, among the slim-shaped molecules, the most active representatives act as competitive inhibitors with the $K_{\mathrm{I}}$ in the range of $24.0-26.4 \mu \mathrm{M}$. Interestingly, the sterically hindered imine derivative with a 3,5-di-tert-butyl-salicylidene unit has the most promising $K_{\mathrm{I}}=17.9 \mu \mathrm{M}$ and acts as an uncompetitive inhibitor. Generally, the values of the constant inhibition classify these compounds as effective agents that inhibit laccase.

We aimed this enzyme as a target since it is secreted by pathogenic fungi, contributing to various plant diseases. We believe that laccase inhibition might prevent or weaken pathogen attacks by chemical protection. Continuing our previous study, in the present article, we have addressed the effect of changing the structure of the acyl unit in hydrazidehydrazones while retaining their salicylidene character on laccase activity, see Figure 2.

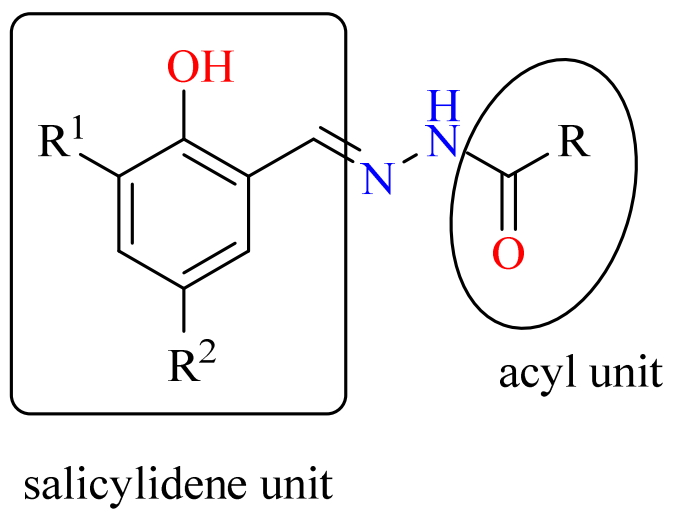

Figure 2. The general structure of investigated hydrazide-hydrazones. The fragment derived from salicylic aldehydes is a salicylidene unit, and the acyl unit originated from acid hydrazides.

\section{Results and Discussion}

\subsection{Syntheses and Characterizations}

We synthesized and investigated the new phenolic hydrazide-hydrazones as a part of our ongoing project to discover aromatic compounds as antifungal and antiviral agents and key enzyme inhibitors of pathogenic microorganisms and viruses [31,85-90]. The target products were synthesized in a three-step procedure starting from carboxylic acid $\mathbf{1}$ via carboxylic acid methyl ester $\mathbf{2}$ [91] as the first intermediate product. The final hydrazidehydrazone products 3-5 [31] were obtained by the direct condensation reaction of salicylic aldehydes 6-9 [92,93] and carboxylic acid hydrazides 10-19 [94], using the literature procedure [31], Scheme 1, Table 1. Products 3-5 were formed quantitatively and characterized. The high purity samples for the enzymatic study were prepared by direct crystallization from the reaction mixtures with a good to almost quantitative yield between 81 and $99 \%$. 


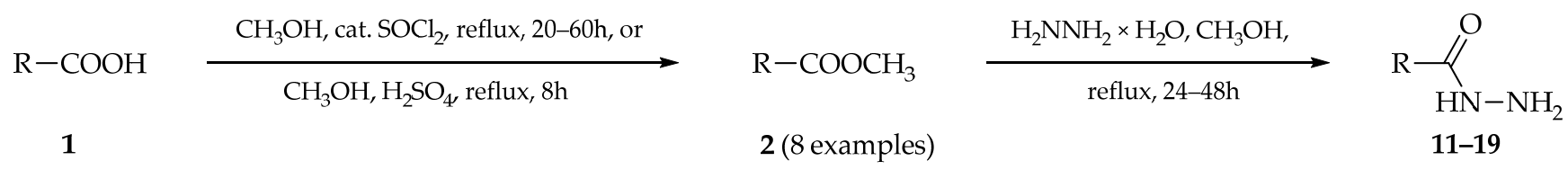

1h, 2h, 19: $\mathrm{R}=2$-(1-HOnaphthoyl); 2a, 12: $\mathrm{R}=3$-pyridyl; 2b, 11: $\mathrm{R}=4-\mathrm{HOC}_{6} \mathrm{H}_{4} \mathrm{CH}_{2} ; 2 \mathrm{c}, 14: \mathrm{R}=3-\mathrm{MeOC}_{6} \mathrm{H}_{4}$; 2d, 15: $\mathrm{R}=4-\mathrm{MeOC}_{6} \mathrm{H}_{4} ; 2 \mathrm{e}, 16: \mathrm{R}=2-\mathrm{HOC}_{6} \mathrm{H}_{4} ; 2 \mathrm{f}, 18: \mathrm{R}=3-\mathrm{HOC}_{6} \mathrm{H}_{4} ; 2 \mathrm{~g}, 13: \mathrm{R}=\mathrm{C}_{6} \mathrm{H}_{5} ; 2 \mathrm{i}, 17: \mathrm{R}=3,5-\mathrm{HOC}_{6} \mathrm{H}_{3}$

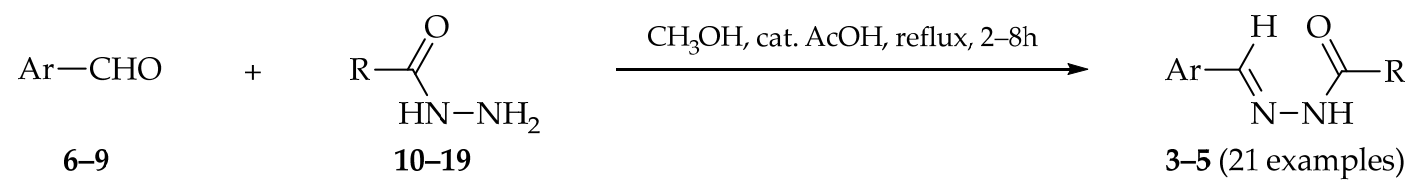

3: $\mathrm{R}=\mathrm{Me}, 4-\mathrm{HOC}_{6} \mathrm{H}_{4} \mathrm{CH}_{2} ; 4: \mathrm{R}=\mathrm{C}_{6} \mathrm{H}_{5}, 3-$ pyridyl, 2- $\mathrm{HOC}_{6} \mathrm{H}_{4}, 3-\mathrm{HOC}_{6} \mathrm{H}_{4}, 3-\mathrm{MeOC}_{6} \mathrm{H}_{4}, 4-\mathrm{MeOC}_{6} \mathrm{H}_{4}, 3,5-(\mathrm{HO})_{2} \mathrm{C}_{6} \mathrm{H}_{3}$;

5: $\mathrm{R}=2-(1-\mathrm{HOnaphthoyl}) ; 6: \mathrm{Ar}=2-\mathrm{HO}-3-\mathrm{Bu}-5-\mathrm{MeC}_{6} \mathrm{H}_{2} ; 7: \mathrm{Ar}=2-\mathrm{HO}-3-\mathrm{BuC}_{6} \mathrm{H}_{3} ; 8: \mathrm{Ar}=2-\mathrm{HO}-3-\mathrm{PhC}_{6} \mathrm{H}_{3}$;

9: $\mathrm{Ar}=2-\mathrm{HO}-3,5-(t \mathrm{Bu})_{2} \mathrm{C}_{6} \mathrm{H}_{2} ; 10: \mathrm{R}=\mathrm{Me}$

Scheme 1. Preparation of hydrazide-hydrazones $3 \mathbf{a}-\mathbf{b}, \mathbf{4 a}-\mathbf{0}$, and $\mathbf{5 a}-\mathbf{d}$ scheme started from carboxylic acids $\mathbf{1}$ via carboxylic acid methyl esters 2 and carboxylic acid hydrazides 11-19.

Table 1. Characteristics of the hydrazide-hydrazones $\mathbf{3 a - b}, \mathbf{4 a - 0}$, and $\mathbf{5 a - d}$.

\begin{tabular}{|c|c|c|c|c|c|c|c|c|}
\hline No. & Ar & $\mathbf{R}$ & Yield, (\%) & $\mathrm{M}_{\mathrm{p}},\left({ }^{\circ} \mathrm{C}\right)$ & $\mathrm{C}=\mathrm{O}^{\mathrm{a}, \mathrm{b}}$ & $\mathrm{N}-\mathrm{H}^{\mathrm{b}, \mathrm{c}}$ & $\mathrm{C}=\mathrm{N}^{\mathrm{b}}$ & $\mathrm{C}_{\mathrm{Ar}}-\mathrm{O}^{\mathrm{b}}$ \\
\hline $3 a$ & 3- $t \mathrm{Bu}-2-\mathrm{HO}-5-\mathrm{MeC}_{6} \mathrm{H}_{2}$ & $\mathrm{Me}$ & 84 & $231-233$ & 1654 & 1614 & 1565 & 1239 \\
\hline $3 b$ & 3- $t \mathrm{Bu}-2-\mathrm{HO}-5-\mathrm{MeC}_{6} \mathrm{H}_{2}$ & $4-\mathrm{HOC}_{6} \mathrm{H}_{4} \mathrm{CH}_{2}$ & 85 & $242-244$ & 1654 & 1612 & 1552 & 1261 \\
\hline $4 a$ & 3- $t \mathrm{Bu}-2-\mathrm{HO}-5-\mathrm{MeC}_{6} \mathrm{H}_{2}$ & 3-pyridyl & 93 & $230-232$ & 1638 & 1590 & 1552 & 1261 \\
\hline $4 b$ & 3- $t \mathrm{Bu}-2-\mathrm{HO}-5-\mathrm{MeC}_{6} \mathrm{H}_{2}$ & $\mathrm{C}_{6} \mathrm{H}_{5}$ & 96 & $246-248$ & 1635 & 1612 & 1561 & 1264 \\
\hline $4 c$ & 3- $t \mathrm{Bu}-2-\mathrm{HO}-5-\mathrm{MeC}_{6} \mathrm{H}_{2}$ & $3-\mathrm{MeOC}_{6} \mathrm{H}_{4}$ & 93 & $238-240$ & 1633 & 1584 & 1560 & 1241 \\
\hline $4 d$ & 3- $t \mathrm{Bu}-2-\mathrm{HO}-5-\mathrm{MeC}_{6} \mathrm{H}_{2}$ & $4-\mathrm{MeOC}_{6} \mathrm{H}_{4}$ & 81 & $243-244$ & 1636 & 1605 & 1537 & 1235 \\
\hline $4 e$ & 3- $t \mathrm{Bu}-2-\mathrm{HO}-5-\mathrm{MeC}_{6} \mathrm{H}_{2}$ & $2-\mathrm{HOC}_{6} \mathrm{H}_{4}$ & 95 & $252-254$ & 1637 & 1615 & 1560 & 1235 \\
\hline $4 f$ & 3- $t \mathrm{Bu}-2-\mathrm{HO}-5-\mathrm{MeC}_{6} \mathrm{H}_{2}$ & $3,5-(\mathrm{HO})_{2} \mathrm{C}_{6} \mathrm{H}_{3}$ & 83 & $246^{\mathrm{d}}$ & 1643 & 1583 & 1556 & 1265 \\
\hline $4 \mathrm{~g}$ & $3,5-(t \mathrm{Bu})_{2}-2-\mathrm{HOC}_{6} \mathrm{H}_{2}$ & $2-\mathrm{HOC}_{6} \mathrm{H}_{4}$ & 97 & $233-235^{\mathrm{e}}$ & 1636 & 1584 & 1554 & 1247 \\
\hline $4 \mathrm{~h}$ & $3,5-(t \mathrm{Bu})_{2}-2-\mathrm{HOC}_{6} \mathrm{H}_{2}$ & $3-\mathrm{HOC}_{6} \mathrm{H}_{4}$ & 98 & $273-274$ & 1638 & 1611 & 1567 & 1251 \\
\hline $4 \mathbf{i}$ & $3,5-(t \mathrm{Bu})_{2}-2-\mathrm{HOC}_{6} \mathrm{H}_{2}$ & $3,5-(\mathrm{HO})_{2} \mathrm{C}_{6} \mathrm{H}_{3}$ & 99 & $266^{\mathrm{d}}$ & 1599 & 1583 & 1549 & 1234 \\
\hline $4 j$ & $3-t \mathrm{Bu}-2-\mathrm{HOC}_{6} \mathrm{H}_{3}$ & $2-\mathrm{HOC}_{6} \mathrm{H}_{4}$ & 98 & $218-220$ & 1630 & 1610 & 1552 & 1231 \\
\hline $4 \mathrm{k}$ & $3-t \mathrm{Bu}-2-\mathrm{HOC}_{6} \mathrm{H}_{3}$ & $3-\mathrm{HOC}_{6} \mathrm{H}_{4}$ & 90 & $225-228$ & 1648 & 1590 & 1567 & 1240 \\
\hline 41 & $3-t \mathrm{Bu}-2-\mathrm{HOC}_{6} \mathrm{H}_{3}$ & $3,5-(\mathrm{HO})_{2} \mathrm{C}_{6} \mathrm{H}_{3}$ & 84 & $217-220$ & 1591 & 1591 & 1557 & 1262 \\
\hline $4 \mathrm{~m}$ & $2-\mathrm{HO}-3-\mathrm{PhC}_{6} \mathrm{H}_{3}$ & $2-\mathrm{HOC}_{6} \mathrm{H}_{4}$ & 83 & $224-227$ & 1601 & 1580 & 1559 & 1231 \\
\hline $4 n$ & $2-\mathrm{HO}-3-\mathrm{PhC}_{6} \mathrm{H}_{3}$ & $3-\mathrm{HOC}_{6} \mathrm{H}_{4}$ & 94 & 207-209 & 1651 & 1592 & 1527 & 1227 \\
\hline 40 & $2-\mathrm{HO}-3-\mathrm{PhC}_{6} \mathrm{H}_{3}$ & $3,5-(\mathrm{HO})_{2} \mathrm{C}_{6} \mathrm{H}_{3}$ & 91 & $241-243$ & 1655 & 1592 & 1544 & 1254 \\
\hline $5 a$ & 3- $t \mathrm{Bu}-2-\mathrm{HO}-5-\mathrm{MeC}_{6} \mathrm{H}_{2}$ & 2-(1-hydroxynaphthyl) & 92 & $215-217$ & 1616 & 1581 & 1532 & 1250 \\
\hline $5 b$ & $2-\mathrm{HO}-3-\mathrm{PhC}_{6} \mathrm{H}_{3}$ & 2-(1-hydroxynaphthyl) & 82 & $226-228$ & 1628 & 1600 & 1532 & 1249 \\
\hline $5 c$ & $3,5-(t \mathrm{Bu})_{2}-2-\mathrm{HOC}_{6} \mathrm{H}_{2}$ & 2-(1-hydroxynaphthyl) & $95^{f}$ & $121-123$ & 1611 & 1584 & 1563 & 1250 \\
\hline $5 d$ & $3-t \mathrm{Bu}-2-\mathrm{HOC}_{6} \mathrm{H}_{3}$ & 2-(1-hydroxynaphthyl) & 99 & $220-222$ & 1623 & 1602 & 1565 & 1252 \\
\hline
\end{tabular}

${ }^{a}$ Amide I bond vibrations; ${ }^{\mathrm{b}}$ in $\mathrm{cm}^{-1} ;{ }^{\mathrm{c}}$ amide II bond vibrations; ${ }^{\mathrm{d}}$ Melts with decomposition; ${ }^{\mathrm{e}}$ Literature melting point: 218-222 ${ }^{\circ} \mathrm{C}$ [95], 230-232 ${ }^{\circ} \mathrm{C}[96] ;{ }^{\mathrm{f}}$ Crystallize with one molecule of $\mathrm{CH}_{3} \mathrm{OH}$.

Among the spectroscopic methods used, the infrared spectra are the most diagnostic in the analysis of product formation due to the vanishing of the band with a very strong intensity usually observed around $1700 \mathrm{~cm}^{-1}$ that corresponded to stretching $\mathrm{CH}=\mathrm{O}$ group vibration. Furthermore, the IR method is also helpful in monitoring the reaction progress and determining the product purity. Generally, the ATR-IR spectra of the functionalized salicylaldehyde derivatives 3-5 had an extensive absorption band between $3300-2500 \mathrm{~cm}^{-1}$. This absorption contained bands corresponding to stretching vibrations of $\mathrm{O}-\mathrm{H}, \mathrm{N}-\mathrm{H}$, $\mathrm{C}_{\mathrm{Ar}}-\mathrm{H}$, and $\mathrm{CH}_{2}$ or $\mathrm{CH}_{3}$ of alkyls. The band from stretching vibration of $\mathrm{O}-\mathrm{H}$ bond was not observed in most of the analyzed spectra as a characteristic one. It probably contributed to a mentioned broad absorption typical for crystalline compounds with strong $\mathrm{H}$-bonding [97]. The vibrations of the hydrazide fragment are frequently described as amide vibrations, in which stretching vibration of $\mathrm{C}=\mathrm{O}$ bond is named amide $\mathrm{I}$ and bending vibration of $\mathrm{NH}$ group-amide II. These are relatively strong and the medium absorptions 
found between $1700-1600 \mathrm{~cm}^{-1}$ and $1650-1550 \mathrm{~cm}^{-1}$, respectively. The other characteristic bands expected in the FT-IR spectrum correspond to stretching vibrations of $\mathrm{C}=\mathrm{N}$ and C-O bonds. For all of the hydrazide-hydrazones 3-5, the wavenumbers corresponding to the following vibrations were assigned as following $3248-3164 \mathrm{~cm}^{-1}$ to stretching $\mathrm{N}-\mathrm{H}$ bond, $1655-1591 \mathrm{~cm}^{-1}$ the amide I, $1615-1580 \mathrm{~cm}^{-1}$ amide II, $1567-1527 \mathrm{~cm}^{-1}$ stretching imine bond $(\mathrm{C}=\mathrm{N})$, and $1265-1227 \mathrm{~cm}^{-1}$ to stretching $\mathrm{C}-\mathrm{O}$ phenolic bond. In the cases of methoxylated compounds $4 \mathbf{c}$ and $4 \mathbf{d}$, the following stretching $\mathrm{O}-\mathrm{CH}_{3}$ vibration was observed at $1044 \mathrm{~cm}^{-1}$ and $1029 \mathrm{~cm}^{-1}$, respectively.

The structural similarities of the synthesized hydrazides 11-19 to the corresponding hydrazide-hydrazones 3-5 resulted in partial coverage of the wavelength values in their IR spectra. The broad absorption between $3300-2500 \mathrm{~cm}^{-1}$ contained stretching vibrations the bands of $\mathrm{NH}_{2}\left(3251-3182 \mathrm{~cm}^{-1}\right)$, and $\mathrm{N}-\mathrm{H}\left(3329-3283 \mathrm{~cm}^{-1}\right)$, and $\mathrm{C}-\mathrm{H}$ alkyl groups vibration in hydrazides 11, 14, and $15\left(2963-2809 \mathrm{~cm}^{-1}\right)$. Band of O-H stretching vibration was also not observed in this region. Absorptions with medium and strong intensities of amide I and amide II vibrations were attributed to bands between $1673-1605 \mathrm{~cm}^{-1}$ and 1604-1547 $\mathrm{cm}^{-1}$, respectively. The other characteristic bands corresponded to the stretching vibration of $\mathrm{C}-\mathrm{O}$ in phenolic and $\mathrm{O}-\mathrm{CH}_{3}$ in alkyl substituents found between $1269-1249 \mathrm{~cm}^{-1}$ and $1034-1030 \mathrm{~cm}^{-1}$, respectively. The stretching vibration of the N-N bond had a weak absorption around $1000-1200 \mathrm{~cm}^{-1}$. Although one nitrogen atom in the N-N group is acylated, it remains highly symmetrical and is not a diagnostic band in infrared spectra [98].

All di-aryl hydrazide-hydrazones numbered $\mathbf{4}$ and $\mathbf{5}$ were isolated as pure geometric isomers $E$. These having acetyl units numbered $\mathbf{3 a}$ and $\mathbf{3 b}$ were isolated as $E$ isomer predominantly with the ratio 79:21 and 87:13, respectively. We determined the ratio of isomers based on $\mathrm{CH}=\mathrm{N}$ integration in ${ }^{1} \mathrm{H}-\mathrm{NMR}$ spectra.

\subsection{Kinetic Studies}

In our previous work, a 4-hydroxybenzoic acid (4-HBA) fragment of choice played a pivotal role in laccase inhibition as a decoy similar to its substrate. We showed that the salicylic aldehyde fragment with a bulky group localized neighbor to the hydroxy group, presented in Figure 3, contributes to a strong stabilizing effect with the hydrophobic area in a substrate-binding pocket [31]. In the present work, we extended the structureactivity relationship (SAR) after the change of acyl fragment (Figure 2) introduced from the carboxylic acid. We preserved the salicylidene unit in hydrazide-hydrazone molecules introduced directly from salicylic aldehyde substrates 6-9.<smiles>O=Cc1cccc(-c2ccccc2)c1O</smiles>

6

$(4 \mathrm{~m}-\mathrm{o}, 5 \mathrm{~b}, 23)$<smiles>CC(C)(C)c1cccc(C=O)c1O</smiles>

7<smiles>Cc1cc(C=O)c(O)c(C(C)(C)C)c1</smiles>

8<smiles>CC(C)(C)c1cc(C=O)c(O)c(C(C)(C)C)c1</smiles>

9

$(4 j-1,5 d) \quad(3 a, 3 b, 4 a-f, 5 a, 20,22)$

Figure 3. The structure of the aldehydes 6-9 used in the synthesis of corresponding target salicylic hydrazide-hydrazones 3-5 and 20-23 control compounds (enumerated in parentheses).

We synthesized a set of twenty-one hydrazide-hydrazones from four salicylic aldehydes of choice 6-9 (Figure 3) and ten differently substituted acid hydrazides 10-19.

Considering the possible interactions of the salicylic acid fragment with a substratebinding site in the enzyme, we used two alkyl hydrazides 10-11 and eight different aromatic acid hydrazides 12-19. The alkyl hydrazides were acetic acid hydrazide $\mathbf{1 0}$ and 
2-(4-hydroxyphenyl)acetic acid hydrazide 11. The aromatic unit contained 3-pyridyl 12, benzoic 13, and the potential substrates for laccase such as $\mathrm{OH}$ and $\mathrm{OMe}$ differently substituted arenes 14-19. Among them, 3-, 4-methoxy-, 2-, 3-hydroxy-, and 3,5-dihydroxybenzoic, 14-15, 16-17, and 18, respectively, and also 2-(1-hydroxy)naphthoic acid hydrazide (19) were used.

Based on the character of the acyl fragment, we formally divided the tested hydrazidehydrazones numbered 3-5 into three groups. The first group contained two alkyl representatives, methyl and 4-hydroxybenzyl in $\mathbf{3} \mathbf{a}$ and $\mathbf{3} \mathbf{b}$, respectively. The second group included a strong electron-deficient 3-pyridyl or phenyl rings in $\mathbf{4 a}$ and $\mathbf{4 b}$, respectively, and an electron-rich phenyl ring having a strong electron-donating methoxy $4 \mathbf{c}$, $4 \mathrm{~d}$, hydroxy $4 \mathrm{e}, 4 \mathrm{~g}, 4 \mathrm{~h}, 4 \mathrm{j}, \mathbf{4 k}, 4 \mathrm{~m}, 4 \mathrm{n}$, and dihydroxy $4 \mathrm{f}, 4 \mathrm{i}, 41,4 \mathrm{o}$ substituents. The structures of the compounds $5 \mathbf{a}-\mathbf{d}$ in the third group contained a bigger 1-hydroxy-2-naphthoyl ring that provides their slim-like character (Table 2). To compare the inhibition potency of new compounds, we chose $\mathrm{NaN}_{3}$ as a classic standard reference. Additionally, we used hydrazide-hydrazone derivatives of 4-HBA numbered 20-22 and 4-methoxybenoic acid derivative 23 negative standards described in our previous work (Table 2) [31].

Table 2. Structures and inhibition constant $\left(K_{\mathrm{I}}, \mu \mathrm{M}\right)$ values of the hydrazide-hydrazones $\mathbf{3 a}-\mathbf{b}, \mathbf{4 a}-\mathbf{o}, \mathbf{5 a}-\mathbf{d}$ determined for laccase (T. versicolor). Crucial $K_{\mathrm{I}}$ values were bolded. The reference compounds are $\mathbf{2 0 - 2 3}$ and $\mathrm{NaN}_{3}$ [31].

\begin{tabular}{|c|c|c|c|c|c|}
\hline No. & $\mathrm{Ar}$ & $\mathbf{R}$ & $K_{I}, \mu \mathrm{M}$ & $\mathbf{R}^{2}$ & Inhibition Type \\
\hline $3 a$ & 3-t $\mathrm{Bu}-2-\mathrm{HO}-5-\mathrm{MeC}_{6} \mathrm{H}_{2}$ & $\mathrm{Me}$ & $-{ }^{a}$ & - & $-b$ \\
\hline $3 b$ & 3- $t \mathrm{Bu}-2-\mathrm{HO}-5-\mathrm{MeC}_{6} \mathrm{H}_{2}$ & $4-\mathrm{HOC}_{6} \mathrm{H}_{4} \mathrm{CH}_{2}$ & 49.2 & 0.960 & uncompetitive \\
\hline $4 a$ & $3-t \mathrm{Bu}-2-\mathrm{HO}-5-\mathrm{MeC}_{6} \mathrm{H}_{2}$ & 3-pyridyl & $-{ }^{c}$ & - & $-\mathrm{b}$ \\
\hline $4 b$ & 3-t $\mathrm{Bu}-2-\mathrm{HO}-5-\mathrm{MeC}_{6} \mathrm{H}_{2}$ & $\mathrm{C}_{6} \mathrm{H}_{5}$ & 82.0 & 0.996 & competitive \\
\hline $4 c$ & $3-t \mathrm{Bu}-2-\mathrm{HO}-5-\mathrm{MeC}_{6} \mathrm{H}_{2}$ & $3-\mathrm{MeOC}_{6} \mathrm{H}_{4}$ & 17.4 & 0.974 & non-competitive \\
\hline $4 d$ & 3- $t \mathrm{Bu}-2-\mathrm{HO}-5-\mathrm{MeC}_{6} \mathrm{H}_{2}$ & $4-\mathrm{MeOC}_{6} \mathrm{H}_{4}$ & 25.8 & 0.984 & competitive \\
\hline $4 e$ & $3-t \mathrm{Bu}-2-\mathrm{HO}-5-\mathrm{MeC}_{6} \mathrm{H}_{2}$ & $2-\mathrm{HOC}_{6} \mathrm{H}_{4}$ & 150.0 & 0.958 & uncompetitive \\
\hline $4 f$ & $3-t \mathrm{Bu}-2-\mathrm{HO}-5-\mathrm{MeC}_{6} \mathrm{H}_{2}$ & $3,5-(\mathrm{HO})_{2} \mathrm{C}_{6} \mathrm{H}_{3}$ & 32.3 & 0.982 & competitive \\
\hline $4 g$ & $3,5-(t \mathrm{Bu})_{2}-2-\mathrm{HOC}_{6} \mathrm{H}_{2}$ & $2-\mathrm{HOC}_{6} \mathrm{H}_{4}$ & 52.6 & 0.998 & non-competitive \\
\hline $4 h$ & $3,5-(t \mathrm{Bu})_{2}-2-\mathrm{HOC}_{6} \mathrm{H}_{2}$ & $3-\mathrm{HOC}_{6} \mathrm{H}_{4}$ & 18.9 & 0.996 & competitive \\
\hline $4 i$ & $3,5-(t \mathrm{Bu})_{2}-2-\mathrm{HOC}_{6} \mathrm{H}_{2}$ & $3,5-(\mathrm{HO}){ }_{2} \mathrm{C}_{6} \mathrm{H}_{3}$ & 55.6 & 0.961 & competitive \\
\hline $4 j$ & $3-t \mathrm{Bu}-2-\mathrm{HOC}_{6} \mathrm{H}_{3}$ & $2-\mathrm{HOC}_{6} \mathrm{H}_{4}$ & 65.6 & 0.965 & uncompetitive \\
\hline $4 \mathbf{k}$ & $3-t \mathrm{Bu}-2-\mathrm{HOC}_{6} \mathrm{H}_{3}$ & $3-\mathrm{HOC}_{6} \mathrm{H}_{4}$ & 35.8 & 0.994 & competitive \\
\hline 41 & $3-t \mathrm{Bu}-2-\mathrm{HOC}_{6} \mathrm{H}_{3}$ & $3,5-(\mathrm{HO}){ }_{2} \mathrm{C}_{6} \mathrm{H}_{3}$ & 38.0 & 0.923 & competitive \\
\hline $\mathrm{m}$ & 2- $\mathrm{HO}-3-\mathrm{PhC}_{6} \mathrm{H}_{2}$ & 2- $\mathrm{HOC}_{6} \mathrm{H}_{4}$ & 26.4 & 0.982 & competitive \\
\hline $4 \mathrm{~m}$ & $2-\mathrm{HO}-3-\mathrm{PhC}_{6} \mathrm{H}_{3}$ & $2-\mathrm{HOC}_{6} \mathrm{H}_{4}$ & 57.1 & 0.959 & uncompetitive \\
\hline $4 n$ & & $3-\mathrm{HOC}_{6} \mathrm{H}_{4}$ & 233 & 0.976 & competitive \\
\hline $4 n$ & $2-\mathrm{HO}-3-\mathrm{PhC}_{6} \mathrm{H}_{3}$ & $3-\mathrm{HOC}_{6} \mathrm{H}_{4}$ & 139 & 0.964 & non-competitive \\
\hline 40 & $2-\mathrm{HO}-3-\mathrm{PhC}_{6} \mathrm{H}_{3}$ & $3,5-(\mathrm{HO}){ }_{2} \mathrm{C}_{6} \mathrm{H}_{3}$ & 69.9 & 0.977 & non-competitive \\
\hline $5 a$ & 3-t $\mathrm{Bu}-2-\mathrm{HO}-5-\mathrm{MeC}_{6} \mathrm{H}_{2}$ & 2-(1-hydroxynaphthyl) & 19.0 & 0.993 & competitive \\
\hline $5 a$ & $3-t \mathrm{Bu}-2-\mathrm{HU}-5-\mathrm{NleC}_{6} \mathrm{H}_{2}$ & 2-(1-hydroxynaphthyl) & 8.0 & 0.982 & non-competitive \\
\hline $5 \mathrm{~h}$ & & 2-(1-hydroxynaphthyl) & 25.8 & 0.950 & competitive \\
\hline $5 b$ & $2-\mathrm{HO}-3-\mathrm{PhC}_{6} \mathrm{H}_{3}$ & 2-(1-hydroxynaphthyl) & 24.3 & 0.999 & non-competitive \\
\hline $5 c$ & $3,5-(t \mathrm{Bu})_{2}-2-\mathrm{HOC}_{6} \mathrm{H}_{2}$ & 2-(1-hydroxynaphthyl) & 16.2 & 0.998 & non-competitive \\
\hline $5 d$ & $3-t \mathrm{Bu}-2-\mathrm{HOC}_{6} \mathrm{H}_{3}$ & 2-(1-hydroxynaphthyl) & 75.2 & 0.971 & competitive \\
\hline & & & 55.6 & 0.999 & non-competitive \\
\hline $20^{d}$ & 3-tBu-2-HO-5- $\mathrm{MeC}_{6} \mathrm{H}_{2}$ & $4-\mathrm{HOC}_{6} \mathrm{H}_{4}$ & $26.4[31]$ & - & competitive \\
\hline $21^{d}$ & $3,5-(t \mathrm{Bu})_{2}-2-\mathrm{HOC}_{6} \mathrm{H}_{2}$ & $4-\mathrm{HOC}_{6} \mathrm{H}_{4}$ & 17.9 [31] & - & uncompetitive \\
\hline $22^{d}$ & 3- $t \mathrm{Bu}-2-\mathrm{HO}-5-\mathrm{MeC}_{6} \mathrm{H}_{2}$ & $3-\mathrm{HOC}_{6} \mathrm{H}_{4}$ & $32.0[31]$ & - & non-competitive \\
\hline $23^{d}$ & $2-\mathrm{HO}-3-\mathrm{PhC}_{6} \mathrm{H}_{3}$ & $4-\mathrm{MeOC}_{6} \mathrm{H}_{4}$ & $\geq 1000[31]$ & - & $-b^{b}$ \\
\hline- & \multicolumn{2}{|c|}{$\mathrm{NaN}_{3} \mathrm{~d}$} & $2.7[31]$ & & non-competitive \\
\hline
\end{tabular}

${ }^{\mathrm{a}}$ Not active up to $1000 \mu \mathrm{M}$ of concentration tested, ${ }^{\mathrm{b}}$ not determined, ${ }^{\mathrm{c}}$ insoluble in medium, $\mathrm{K}_{\mathrm{I}}$-an inhibition constant, determined for a related type of inhibition according to reference [99], ${ }^{\mathrm{d}}$ controls [31].

The kinetic studies showed that the nineteen hydrazide-hydrazones exhibited an inhibition potency in the micromolar range of $K_{\mathrm{I}}$ between $8.0-233 \mu \mathrm{M}$ and different modes of interaction with the enzyme molecules. Nine compounds $\mathbf{3} \mathbf{a}-\mathbf{b}, \mathbf{4} \mathbf{a}-\mathbf{f}$, and $\mathbf{5 a}$ (Table 2) 
contain the 3-tert-butyl-5-methyl-salicylidene leading motif introduced from aldehyde 8 (Figure 2). We used previously reported hydrazide-hydrazone 20 derived from leading aldehyde 8 and 4-hydroxybenzoic acid hydrazide to compare the kinetic results. It acted as the competitive inhibitor with a constant $K_{\mathrm{I}}=26.4 \mu \mathrm{M}$. Among the hydrazide-hydrazones, the acetyl derivative $\mathbf{3} \mathbf{a}$, and nicotinoyl derivative $\mathbf{4 a}$, were not active at the desirable micromolar range. The benzoyl derivative $4 \mathrm{~b}$ had a moderate activity with $K_{\mathrm{I}}=82.0 \mu \mathrm{M}$. Comparing it with $\mathbf{3 b}$ derivative with para hydroxylated benzene ring with methylene linker, almost a two-fold improvement of inhibition activity was observed $\left(K_{\mathrm{I}}=49.1 \mu \mathrm{M}\right)$. On the other hand, the alteration from standard 20 having the 4-hydroxyphenyl framework to above compound $\mathbf{3 b}$ resulted in an almost two-fold drop in the activity, which confirmed our predictions that the hydroxylated aromatic fragment serves as a decoy and is required on the benzoyl fragment. Despite the $\mathbf{3 b}$ seeming structurally like laccase substrate, the distance of the para-hydroxylated phenyl ring of the molecule core resulted in its higher affinity to the enzyme-substrate complex (Figure 4). Similar to $\mathbf{3} \mathbf{b}$, the more hindered salicylic acid derivatives, the $4 \mathbf{e}, \mathbf{4 g}, \mathbf{4 j}$, and $\mathbf{4 m}$, also did not act as competitive inhibitors. Among the discussed compounds, $4 \mathbf{e}$ molecule acted as an uncompetitive laccase inhibitor, which corresponded to dropped inhibition potency approximately six-fold compared to the control 20, both derivatives of our leading aldehyde. As it resulted from kinetic measurements, removing the smallest alkyl group in the 5-position of the aldehyde fragment increases the inhibition potency from $150 \mu \mathrm{M}$ to $65.6 \mu \mathrm{M}$ for $4 \mathbf{e}$ and $4 \mathbf{j}$ compounds, respectively, simultaneously preserving the uncompetitive type of action.

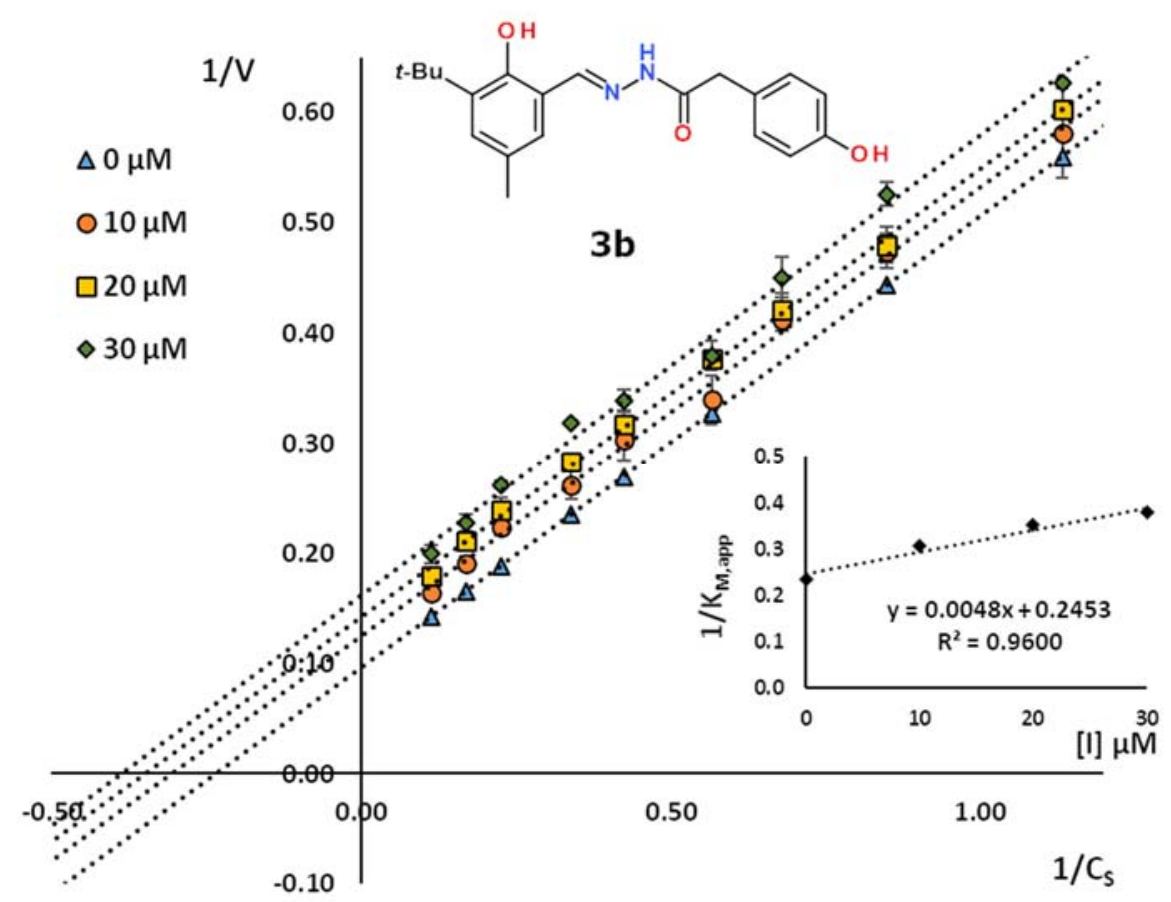

Figure 4. The Lineweaver-Burk plots $\left(1 / \mathrm{V}\left[\mathrm{min} \cdot \mu \mathrm{M}^{-1}\right]=f\left(1 / \mathrm{C}_{\mathrm{S}}\right)\left[\mu \mathrm{M}^{-1}\right]\right)$ for $3 \mathbf{b}$ performed for the inhibitor concentration up to $30 \mu \mathrm{M}$. The additional graphs show the linear dependence of $1 / K_{M, a p p}=f(I)[\mu M]$ related to the uncompetitive mechanism.

On the other hand, replacing the 3-tert-butyl group in $4 \mathbf{j}$ on a phenyl ring in $4 \mathbf{m}$ resulted in a change of inhibition mechanism to a mixed type. Such structural modification in $4 \mathrm{~m}$ improved the value of constant inhibition of competitive component to $26.4 \mu \mathrm{M}$, at the same value as for the control 20. Comparing the compounds having bulky 3,5-ditert-butyl-2-hydroxy-benzylidene unit showed that a change of 4-hydroxybenzoyl group in control $\mathbf{2 1}$ to 2 -hydroxybenzoyl in $\mathbf{4} \mathbf{g}$ resulted in a three-fold decrease in inhibition activity. Interestingly, the only exception was the derivative $4 \mathrm{~m}$ of 2-hydroxybenzoyl and 3- 
phenyl-salicylidene units, for which the value of the competitive component $K_{\mathrm{I}}=26.4 \mu \mathrm{M}$ remained the same as for control 20.

Well-known facts supported the choice of the salicylic acid hydrazide as the substrate for synthesizing potent hydrazide-hydrazone laccase inhibitors. Salicylic acid (SA) is a natural signaling molecule that activates plant defense responses to a pathogen attack $[100,101]$. The SA functional analogs are applied in the crop protection sector [102], and the salicylic acid [103] and a sulphonyl salicylic acid [104] are not laccase substrates. Moreover, the SA is not a promotor of laccase production in white-rot fungi culture [105].

The remaining hydrazide-hydrazones of the second group are also benzoyl monoand di-hydroxylated in 3-position or 3,5-positions derivatives $4 \mathbf{h}, 4 \mathbf{k}, 4 \mathbf{n}$ or $4 \mathbf{f}, 4 \mathbf{i}, 4 \mathbf{l}$, 4o, respectively. Five of seven compounds were pure competitive inhibitors with good inhibition potency between 18.9-35.8 $\mu \mathrm{M}$ and 32.3-55.6 $\mu \mathrm{M}$ for mono- and di-substituted, respectively. Comparison of appropriate pairs of 3-hydroxy and 3,5-dihydroxy ( $\alpha$-resorcinic acid unit) derivatives 22 and $4 \mathbf{f}, 4 \mathrm{~h}$ and $4 \mathbf{i}$, and $4 \mathbf{k}$ and 41 showed their inhibition potency and the beneficial effect of benzoyl fragments on laccase inhibition. Compounds $4 \mathbf{k}$ and $4 \mathbf{1}$ and 22 and $4 \mathrm{f}$ had comparable inhibition effects, and these pairs derived from aldehyde 7 and 8 differ the $\mathrm{CH}_{3}$ group in 5-position, respectively, see Figure 3. We observed the most significant difference between the last pair of inhibitors $4 \mathrm{~h}$ and $4 \mathrm{i}$ with a common backbone of di-tert-butyl-salicylic aldehyde (9). These compounds acted as competitive inhibitors. For example, see Figure 5 for mono-hydroxylated on acyl unit derivative $4 \mathrm{~h}$. This molecule was three-fold more effective than its disubstituted counterpart $4 \mathbf{i}$, because the crowded phenolic rings seemed too large to effectively interact with the substrate cavity.

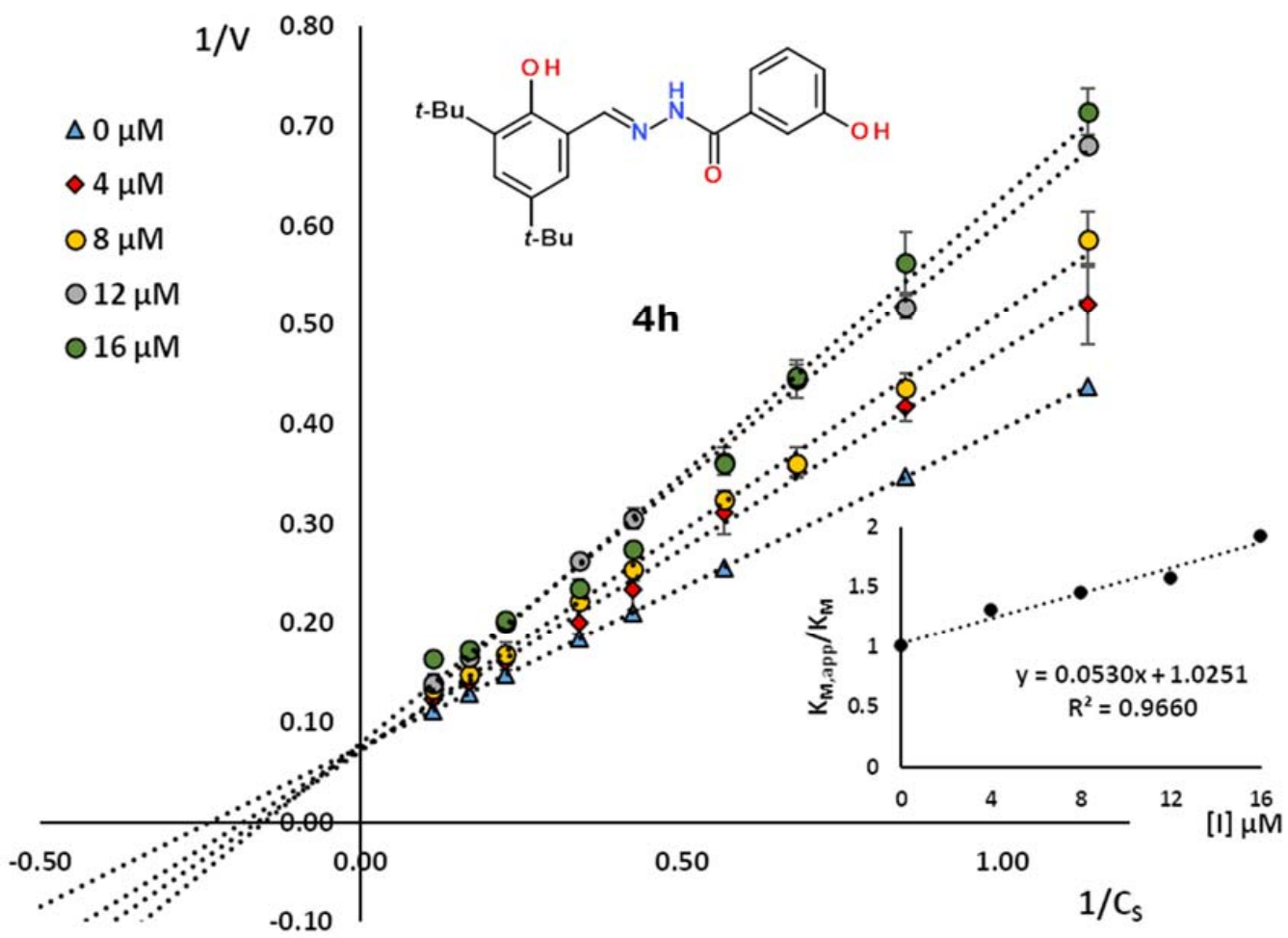

Figure 5. The Lineweaver-Burk plots $\left(1 / V\left[\min \mu M^{-1}\right]=f\left(1 / C_{S}\right)\left[\mu M^{-1}\right]\right)$ for 4 h performed for the inhibitor concentration up to $16 \mu \mathrm{M}$. The additional graphs show the linear dependence of $K_{\mathrm{M}, \text { app }} / K_{\mathrm{M}}=\mathrm{f}(\mathrm{I})$ concerning the competitive mechanism.

In general, a hydroxy group in meta-position may offer preferential interactions with the substrate cavity in the enzyme. Changes in the positioning of the single 3-OH group may occur by flipping around the axis $\mathrm{C} 1-\mathrm{C} 4$ of the benzoyl ring. We expected a similar but strengthened interaction for disubstituted $\alpha$-resorcinic acid hydrazide. In this case, 
interaction in symmetrically localized hydroxy groups was probably slightly weaker or unfavorable to the fit of the molecules in the active site.

Two remaining compounds, $\mathbf{4 o}$ and $\mathbf{4 n}$, have a common 3-phenyl salicylaldehyde fragment. These present the lowest inhibition potency between 69.9 and $233 \mu \mathrm{M}$ with the mixed or non-competitive type of inhibition. On the other hand, these derivatives showed improved activities compared to an inactive control $\mathbf{2 3}$ with the aldehyde $\mathbf{6}$ core but methoxy substituent in acyl fragment. It seems that the bulky electron-rich phenolic substituent represents adverse properties to bind to the substrate-binding cavity. Interestingly, the hydrazide-hydrazone $\mathbf{4 c}$ and $\mathbf{4 d}$, which are methoxylated in meta- and para position of benzoyl unit and containing the common aldehyde 8 core, are the most active in this group. The constants inhibition of $4 \mathbf{c}$ and $4 \mathbf{d}$ are $17.4 \mu \mathrm{M}$ and $25.8 \mu \mathrm{M}$, respectively. The slim $\mathbf{4 d}$ hydrazide-hydrazone has a high affinity to substrate-binding pocket. A mobile methoxy group localized in meta position in $4 \mathbf{c}$ prevented the interaction with the active site of the enzyme (Figure 6). It was in agreement with the reactivity of para-methoxylated arenes such as para-anisic alcohol in the presence of laccase [106]. Further discussion of $\mathrm{OCH}_{3}$ needs developing experimental and theoretical studies, which might also open a new issue about laccase inhibitors.

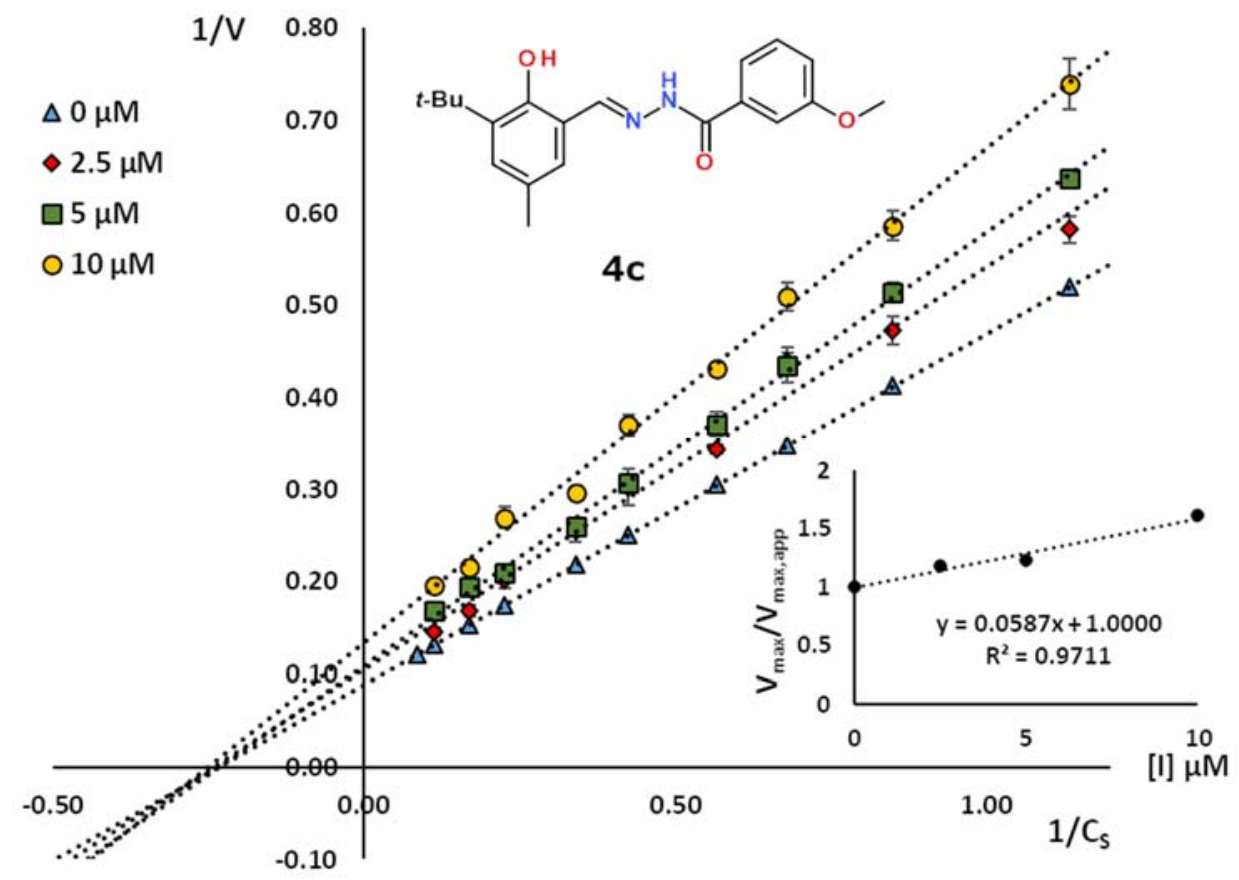

Figure 6. The Lineweaver-Burk plots $\left(1 / V\left[\min \mu \mathrm{M}^{-1}\right]=f\left(1 / C_{S}\right)\left[\mu M^{-1}\right]\right)$ for $4 c$ the inhibitor concentration up to $10 \mu \mathrm{M}$. The additional graphs show the linear dependence of $\mathrm{V}_{\max } / \mathrm{V}_{\max , \text { app }}=\mathrm{f}(\mathrm{I})[\mu \mathrm{M}]$ for non-competitive mechanism.

Finally, the third group numbered 5a-d contains a 2-hydroxynaphtalene hydrazide leading fragment (Table 2). Such substituent would require a large area in the enzymesubstrate cavity for hydrophobic interaction of such a bulk polycyclic arene and provide possible hydrogen bonding with hydrophilic amino acids. As it resulted from form experiments, three out of four compounds acted as mixed inhibitors. For $\mathbf{5 a}, \mathbf{5 b}$, and $\mathbf{5 d}$, the non-competitive component $K_{\mathrm{I}}$ had a consistently lower value than the competitive counterpart. Together with the $\mathbf{5 b}$ derivative, they acted as non-competitive inhibitors preferentially. Furthermore, the magnitude of inhibition constants indicates that the effect of mono-substitution of aldehyde fragment in 3-position ( $\mathbf{5 b}$ and $\mathbf{5 d}$ ) is insufficient to obtain higher inhibition potency than $24.3 \mu \mathrm{M}$ (Table 2). The additional alkyl substituent in 5position improved inhibition potency. The small $\mathrm{CH}_{3}$ group in 5 a preserved the mixed type of inhibition (Figure 7) with a very good value of non-competitive component $K_{\mathrm{I}}=8.0 \mu \mathrm{M}$ and a good value of competitive constant equal to $19.0 \mu \mathrm{M}$. The additional bulk tert-butyl 
group in position 5 in compound $\mathbf{5 c}$ changed the mechanism to pure non-competitive with relatively good $K_{\mathrm{I}}=16.2 \mu \mathrm{M}$. The found hydrazide-hydrazones with the highest activity towards laccase will be the subject of further research on SAR and future application to protect cultivating plans against phytopathogenic fungi [107].

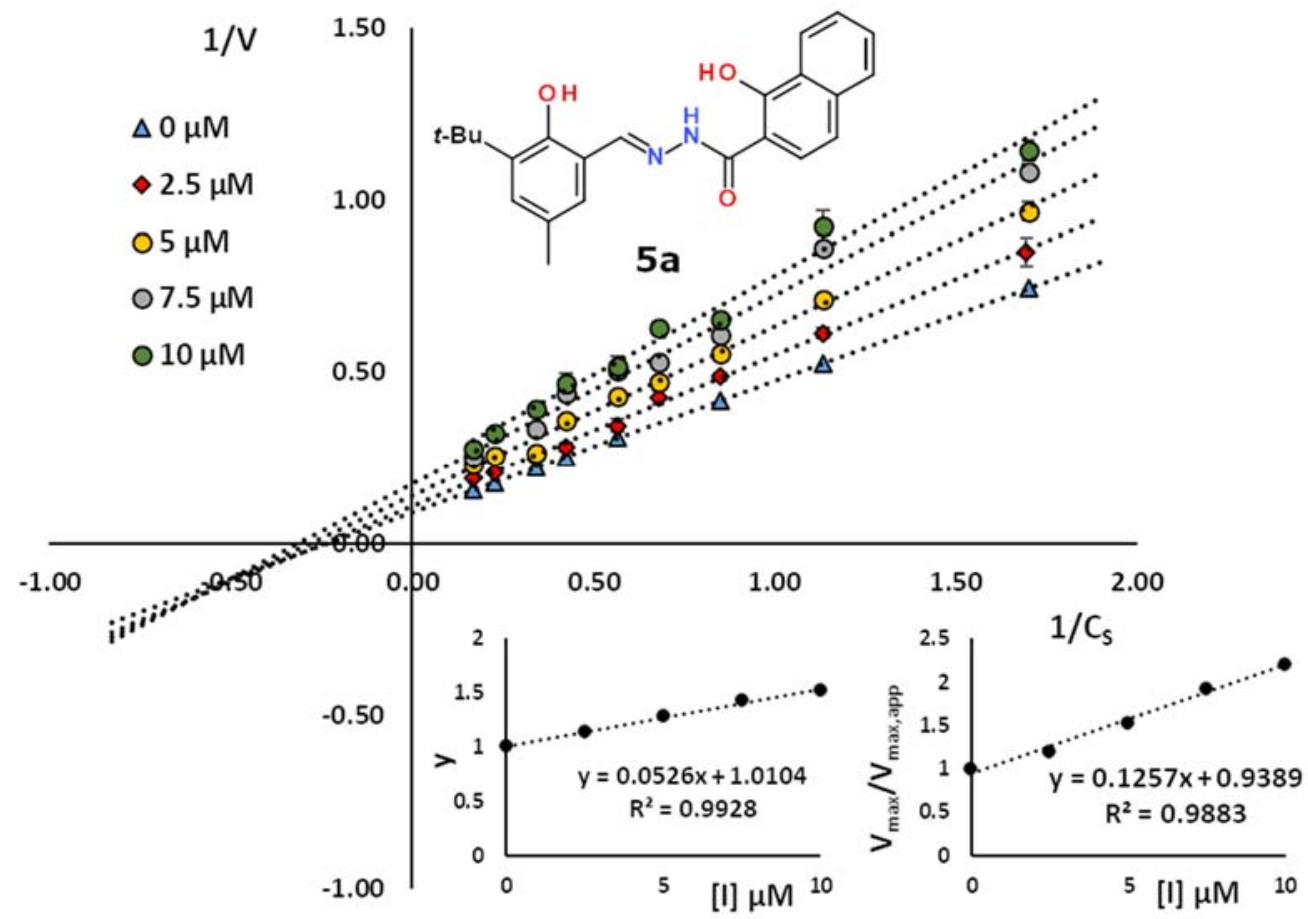

Figure 7. The Lineweaver-Burk plots $\left(1 / V\left[\min \cdot \mu \mathrm{M}^{-1}\right]=f\left(1 / C_{S}\right)\left[\mu M^{-1}\right]\right)$ for 5 a performed for the inhibitor concentration up to $10 \mu \mathrm{M}$. The additional graphs show the linear dependence of $K_{\mathrm{M}, \text { app }} \cdot \mathrm{V}_{\max } /\left(K_{\mathrm{M}} \cdot \mathrm{V}_{\text {max,app }}\right)=\mathrm{f}(\mathrm{I})$ concerning the competitive component in a mixed type mechanism.

\subsection{Docking Studies}

The compounds used in the enzymatic assay were docked in the active center of the laccase (PDB 1GYC). Used procedures were the same as in the previous publication on our laccase research [25]. This time, however, we decided to put forward a hypothesis and check whether the changes in the inhibition type may depend only on the construction of the active center, previously called the substrate cavity. Especially, that several of the inhibitors we have tested showed a mixed mechanism of inhibition. The amino acids Asp206, Asn208, Asn264, and His258 played a key role in interacting with active compounds. They carry an electron from the substrate to the oxygen cavity. However, the other numerous amino acids building the active site (Figure $8 \mathrm{~A}$ ) have a significant influence on the location of the substrate in the active site. The laccase active center can be divided into two hydrophobic parts and one creating numerous hydrogen bonds. Rather, the compounds we investigated fill the volume of one of the hydrophobic cavities and the area of hydrophilic interactions. The position of selected inhibitors is shown in Figure 8B: compounds with a competitive mechanism are shown as a green mesh, while the others are shown as an orange mesh. The inhibitors with the lowest values of the inhibition constants are shifted deeper into the active center. 
(A)

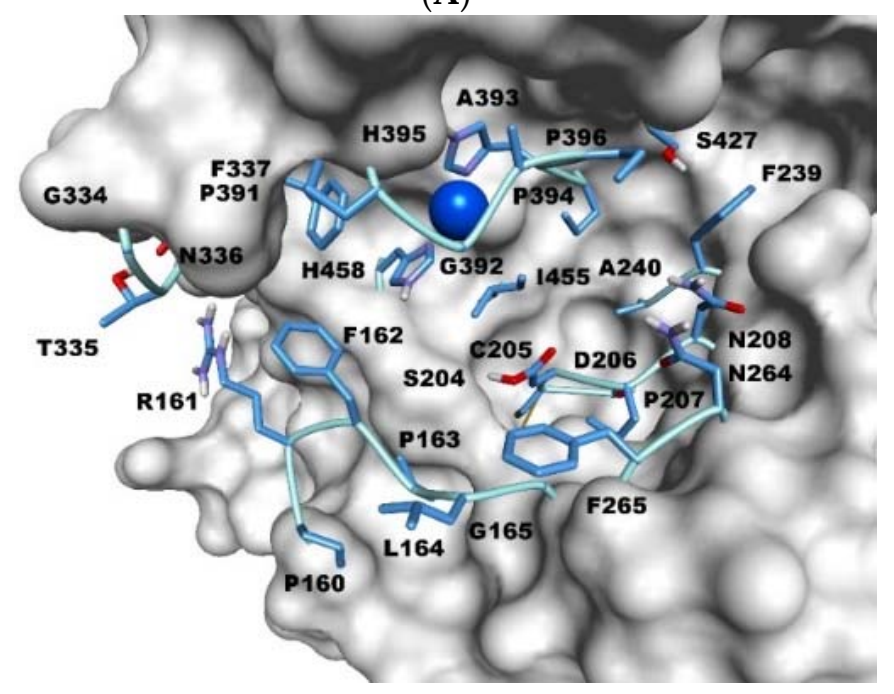

(B)

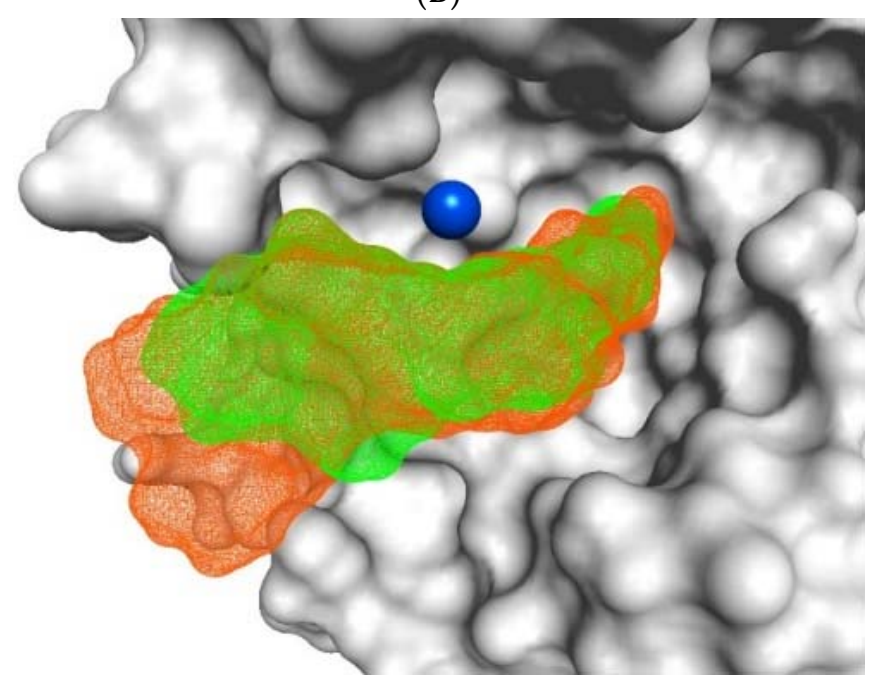

Figure 8. The active center of the laccase (PDB: 1GYC) with selected amino acids building the cavity (A) and the position of investigated inhibitors shown as grids (B). The sidechains of amino acids are shown as blue sticks and the protein is shown as a light blue tube and its surface is colored gray. The $\mathrm{Cu}$ ion is shown as a blue sphere. The mesh of the competitive inhibitors is green, uncompetitive, non-competitive, and mixed is orange.

The compounds used in the enzyme assay were docked to the active site of laccase (PDB 1GYC). The procedures used were the same as in the previous publication on our research on laccase [31]. This time, however, we decided to make a hypothesis and check whether the changes in the type of braking may depend only on the construction of the active center, previously called the ground cavity. Especially since several of the inhibitors we have tested exhibited a mixed inhibition mechanism. The amino acids Asp206, Asn208, Asn264, and His258 played a crucial role in interacting with active compounds. They transfer an electron from the substrate to the oxygen cavity. However, numerous other amino acids building the active site (Figure 8A) have a significant influence on the location of the substrate in the active site. The active site of laccase can be divided into two hydrophobic parts and one forming numerous hydrogen bonds. Rather, the compounds we investigated fill the volume of one of the hydrophobic cavities and the area of hydrophilic interactions. The position of selected inhibitors is shown in Figure 8B: compounds with a competition mechanism are shown as a green grid, while others are shown as an orange grid. Inhibitors with the lowest values of inhibition constants are shifted deeper into the active center.

The pairs of the inhibitors like $4 \mathbf{j}$ and $4 \mathbf{k}$, and $4 \mathrm{~g}$ and $4 \mathrm{~h}$ have a common backbone. The slide difference between them is the position of the hydroxyl group from the hydrazide fragment. That difference plays a key role in the type of binding and inhibition of the compounds. Derivative of salicylic acid $4 \mathbf{j}$ having one tert-butyl group (Figure $9 \mathrm{~A}$ ) is placed like inhibitors from our earlier studies [31]. The hydrophobic ring with the tertbutyl substituent is directed toward the Phe 265 with medium-range aromatic interactions (4.29 ̊). Asp206 is involved in a hydrogen bond with its hydroxyl group $(1.86 \AA)$ and with the backbone nitrogen atom $(2.22 \AA)$. The other hydrogen positioning of the inhibitor is seen by the interactions with Asn208 (2.05 $\AA$ ) and Asn264 (1.85 $\AA$ ). Those close distance non-bond bindings are strengthened by Pro394 (3.60 ^, $5.17 \AA$ ) and Pro396 (4.93 $)$. The derivative $4 \mathbf{k}$ (Figure 9B) with a hydroxy group in meta position has a different inhibition mechanism, and it is slightly moved of the cavity depth. In this case, the hydrazide hydroxyl group interacts with Asn206 (2.20 $)$ ) and Asn264 (2.04 $\AA$ ). The position of the ring is stabilized by extra hydrophobic interactions with Leu164 (5.20 $\AA)$. The carbonyl oxygen atom and the hydrazide nitrogen create a hydrogen bond triangle with His458, and the position of the ring is stabilized by Phe162 (4.22 $⿱$ ) and Pro391 (5.06 $)$. 
(A)

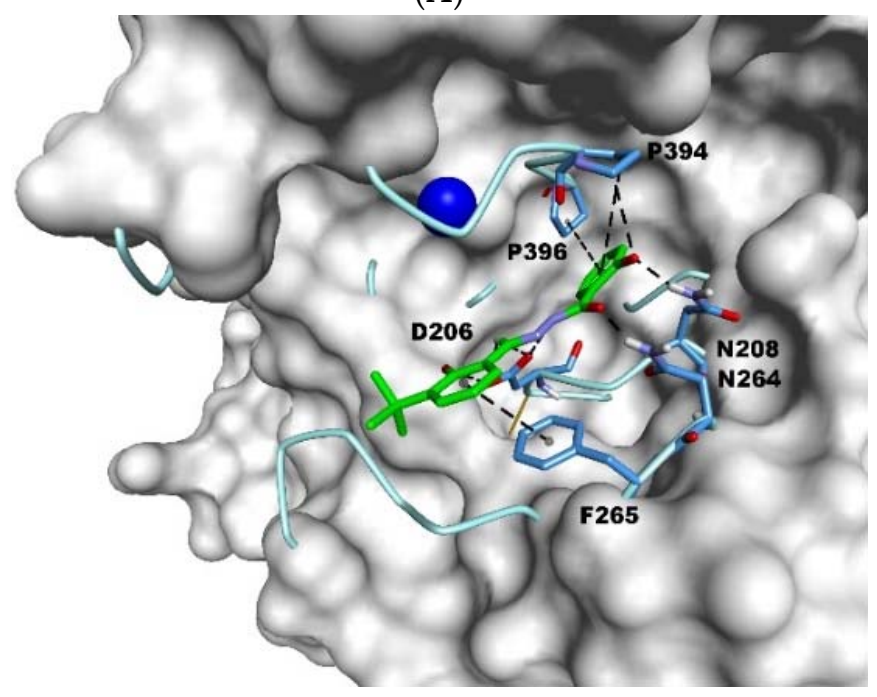

(C)

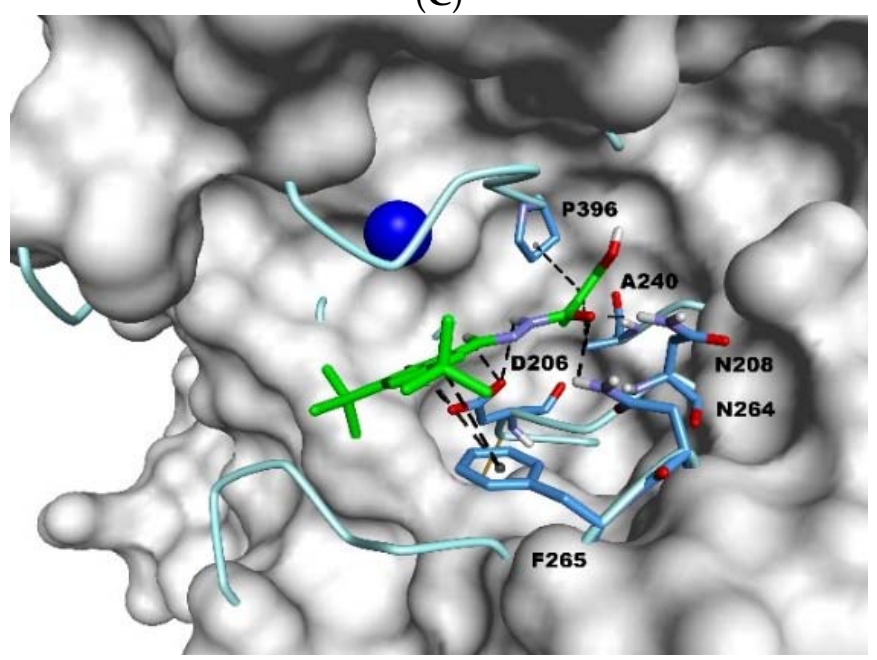

(B)

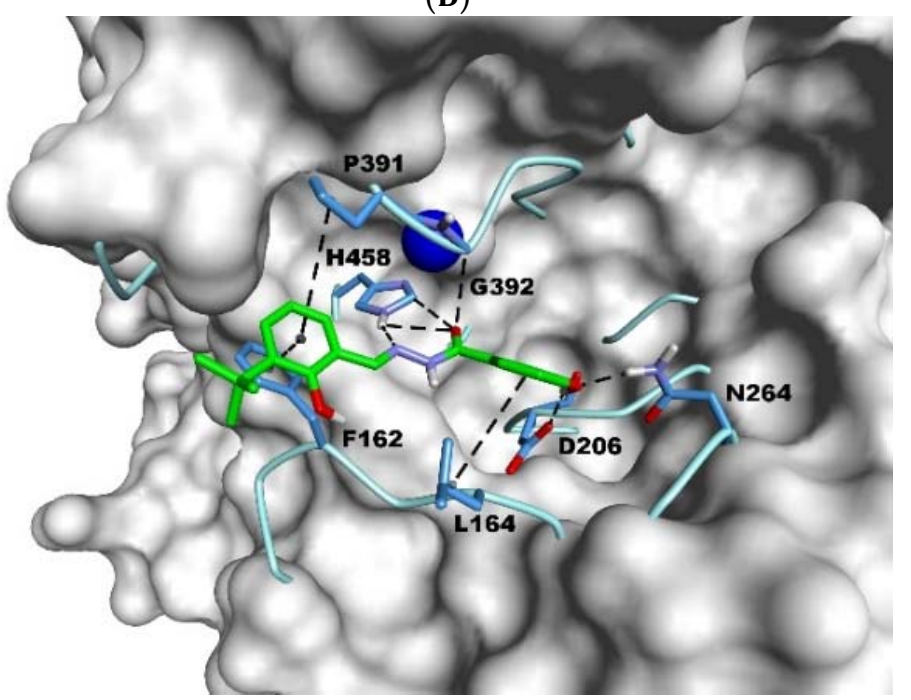

(D)

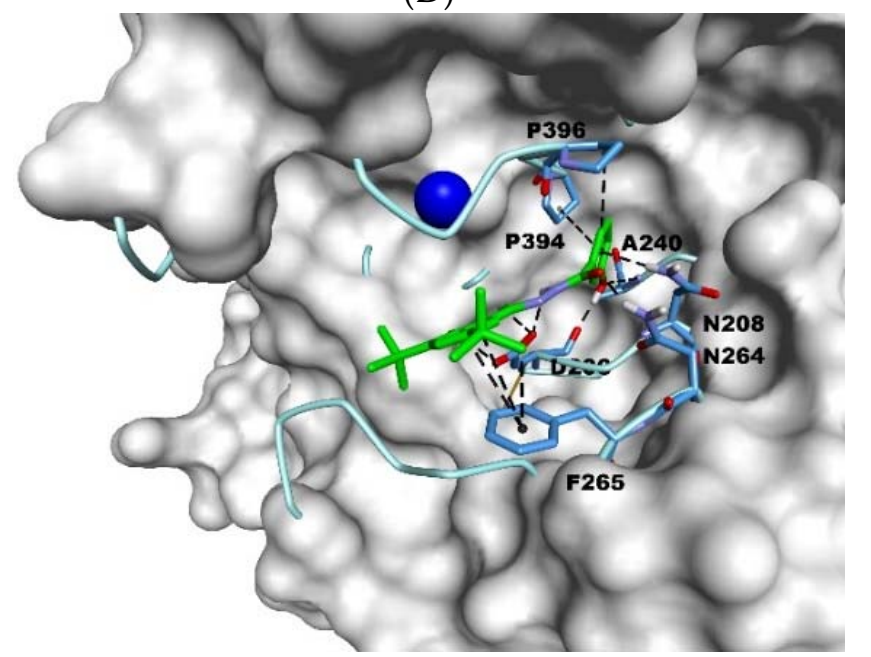

Figure 9. The active center of the laccase (PDB: 1GYC) with the interaction between selected amino acid and inhibitors: $4 \mathbf{j}(\mathrm{A}), \mathbf{4 k}(\mathrm{B}), \mathbf{4 g}(\mathrm{C}), \mathbf{4 h}(\mathrm{D})$. The amino acids are shown as blue sticks and the protein is shown as a light blue tube, and its surface is colored gray. The $\mathrm{Cu}$ ion is shown as a blue sphere. The interactions are black dashed lines.

The larger molecules having two tert-butyl substituents in the salicylidene framework, such as $\mathbf{4 g}$ (Figure 9C) and $4 \mathbf{h}$ (Figure 9D) have less freedom in the binding. They are placed deep in the pocket engaging the same set of amino acids. The different position of a hydroxyl localized on benzoyl unit in ortho vs meta in $\mathbf{4 g}$ and $4 \mathrm{~h}$, respectively, causes the flip of the phenyl ring. Consequently, the extra hydrogen bond between $4 \mathrm{~h}$ and the carbonyl oxygen of the Asp206 (1.67 $\AA$ ) is created. The hydrogen interaction of the hydroxyl group with Asp206 is of the most significant importance in the inhibition mechanism by blocking the flow of electrons. In other instances, the inhibition is by blocking the substrate's access site for the amino acid. The presence of a hydrogen bond between the hydroxy group and Asn208 can also change the type of inhibition from uncompetitive to non-competitive ( $4 \mathbf{j}$ vs $4 \mathrm{~g}$ ). Compounds with methoxy substituents $4 \mathrm{c}$ and $4 \mathbf{d}$ are also pairs of inhibitors with different inhibition types. The meta position of the methoxy group $4 \mathrm{c}$ creates an unpreferred position in the cavity space. The freedom of the rotation is not appreciated in the deep binding of the inhibitor. That creates a phenomenon, the $4 \mathrm{c}$ is turned opposite to the projected mechanism. In contrast, the $4 \mathrm{~d}$ binds properly to the inhibition types and interacts with the Asp206. 
The thesis is also confirmed by analyzing the interaction of more hydrophobic compounds having a naphthoic ring in their structure with amino acids in the active center. Compound 5a (Figure 10A) had the lowest value of the inhibition constant, but it has a mixed mode of inhibition. The low value of the non-competitive inhibition constant for the binding method of this inhibitor is related to the fact that it is located deep but also in its upper part in the active center, blocking access to His458. Additionally, $\mathbf{5} \mathbf{a}$ forms a strong hydrogen bond with Asp206 (1.79 A). The lack of interaction with the amino acids that make up the cavity's lower area is one of the reasons for the dual binding mechanism. However, 5c (Figure 10B) is bound to amino acids of the lower part of the active center but does not interact with the Asp206, and it has the non-competitive type of inhibition.

(A)

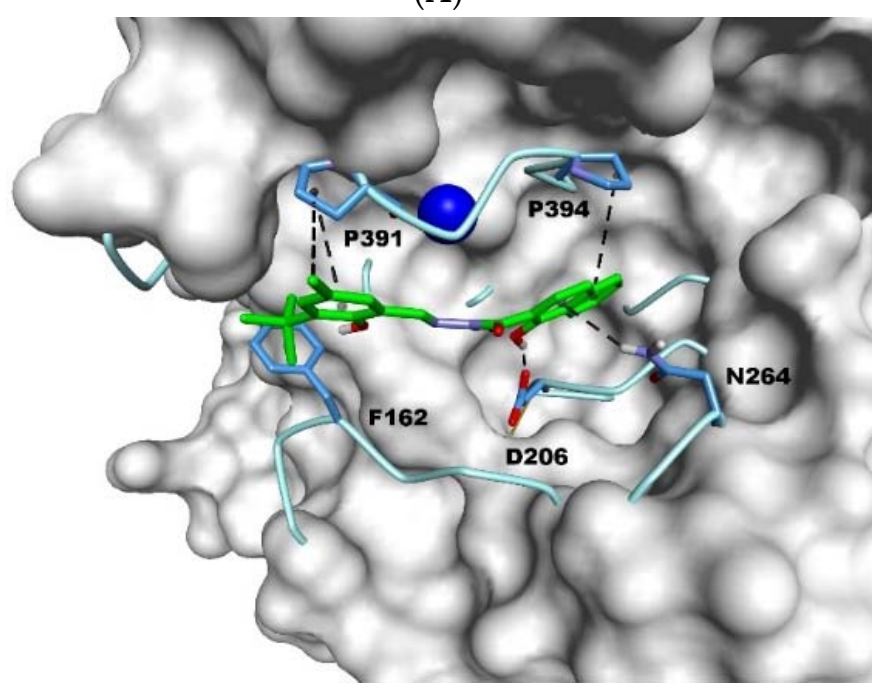

(B)

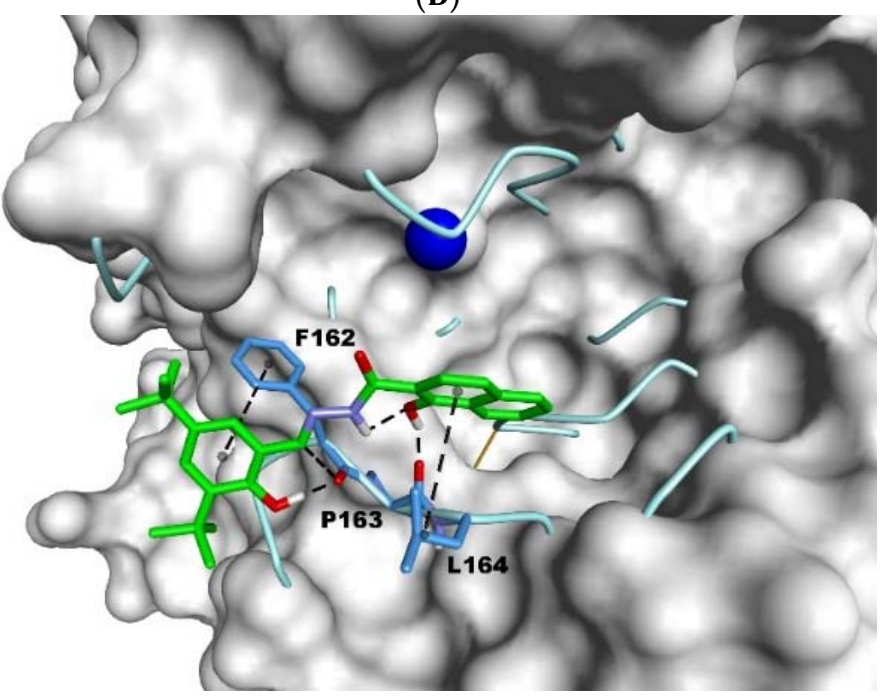

Figure 10. The active center of the laccase (PDB: 1GYC) with the interaction between selected amino acid and inhibitors: $5 \mathbf{a}(\mathbf{A}), \mathbf{5} \mathbf{c}(\mathbf{B})$. The amino acids are shown as blue sticks, and the protein is shown as a light blue tube, and its surface is colored gray. The Fe ion is shown as a blue sphere. The interactions are black dashed lines.

This leads to the conclusion, the compound to inhibit laccase competitively must interact with amino acids from the depths and bottom of the active center, such as Asp206, Asn264, Leu 164, or Phe265. Another criterion required for this type of inhibition is the formation of a strong hydrogen bond between Asp206 and the inhibitor using heteroatoms that do not build the backbone of the inhibitor, blocking the flow of electrons.

\section{Materials and Methods}

All commercially available chemicals were purchased as pure for synthesis or analytical grade reagents (Sigma-Aldrich Poznan, Poland, ARMAR, Wroclaw, Poland) and solvents were used mostly without further purification. In particular, nicotinic acid methyl ester (2a), 2-(4-hydroxyphenyl)-acetic acid methyl ester (2b), 3-tert-butyl-salicylic aldehyde (7), 3,5-di-tert-butyl-salicylic aldehyde (9), acetic acid hydrazide (10), and hydrazine monohydrate purchased in Sigma-Aldrich, and syringaldazine (SNG, 4-hydroxy3,5-dimethoxybenzaldehyde azine), dimethylsulfoxide (DMSO), citric acid monohydrate, and sodium phosphate dibasic dodecahydrate, purchased in POCh (Poland) were used without further purification. Laccase from Trametes versicolor was purchased in lyophilized powder from Sigma-Aldrich (Poznan, Poland).

Methanol $\left(\mathrm{CH}_{3} \mathrm{OH}\right)$ was distilled prior to reactions from $\mathrm{Mg}$ element shavings in the presence of $\mathrm{I}_{2}$. The following substrates such as 3-phenylsalicylicaldehyde (6), 3-tert-butyl5-methylsalicylic aldehyde (8), 4-methoxybenzoic acid hydrazide (15), 3-hydroxybenzoic acid hydrazide (18), and reference hydrazide-hydrazones 4-hydroxy- $N^{\prime}-[(E)$-3-tert-butyl-2hydroxy-5-methylbenzylidene]benzohydrazide (20), 4-hydroxy- $N^{\prime}-[(E)-(3,5-d i-t e r t-b u t y l-2-$ 
hydroxyphenyl)methylidene]benzohydrazide (21), 3-hydroxy- $N^{\prime}-[(E)$-(3-tert-butyl-2-hydroxy5-methylphenyl)methylidene]benzohydrazide (22), and 4-methoxy- $N^{\prime}-[(E)-2$-hydroxy-3phenylbenzylidene]benzohydrazide (23) were synthesized and characterized in our previous work [31]. Analytical TLC was performed on PET foils precoated with silica gel (silica gel, 60 F254, Merck, Darmstadt, Germany), and were made visual under UV light $\left(\lambda_{\max }=254 \mathrm{~nm}\right)$, or by staining with iodine vapor. Melting points were determined on an Electrothermal IA 91100 (ST. Louis, MO, USA) digital melting-point apparatus using the standard open capillary method. FT-IR spectra $\left(4000-400 \mathrm{~cm}^{-1}\right)$ were recorded as $\mathrm{KBr}$ plates on a Perkin-Elmer 2000 FT-IR (Manchester, UK) or Bruker VERTEX 70V spectrometer using a diamond ATR accessory and Nicolet iS50 spectrometer (Thermo Fisher SCIENTIFIC, Waltham, MA, USA) with a resolution of $4 \mathrm{~cm}^{-1}$ at wavenumbers in the range of $500-4000 \mathrm{~cm}^{-1}$. Absorption maxima were reported in wavenumbers $\left(\mathrm{cm}^{-1}\right) .{ }^{1} \mathrm{H}-\mathrm{NMR}$ and ${ }^{13} \mathrm{C}$-NMR spectra were recorded on a Bruker DRX 300 Spectrometer $\left(300.13\right.$ for ${ }^{1} \mathrm{H}$ and 75.475 for ${ }^{13} \mathrm{C}$ ) on Jeol 400yh (Tokio, Japan) (399.78 for ${ }^{1} \mathrm{H}$ and 100.52 for ${ }^{13} \mathrm{C}$ ) or a Bruker Advance 600 Spectrometer (Poznan, Poland) (600.58 for ${ }^{1} \mathrm{H}$ and 151.03 for ${ }^{13} \mathrm{C}$ ) at $295 \mathrm{~K}$. Chemical shifts $(\delta)$ are given in parts per million (ppm) downfield relative to TMS, and coupling constants $(J)$ are in $\mathrm{Hz}$. Residual solvent central signals were recorded as follows: DMSO- $d_{6}, \delta_{\mathrm{H}}=2.500, \delta_{\mathrm{C}}=39.43 ; \mathrm{CH}_{3} \mathrm{OH}-d_{4}, \delta_{\mathrm{H}}=3.310, \delta_{\mathrm{C}}=49.05 ; \mathrm{CDCl}_{3}$, $\delta_{\mathrm{H}}=7.263, \delta_{\mathrm{C}}=77.00$. When measured, DEPT and ATP experiments signals are referred to as $(+)$ or $(-)$. High-resolution mass spectra (HRMS) were recorded on a Waters LCD Premier XE instrument (Manchester, UK), and only the $[\mathrm{M}+\mathrm{H}]^{+}$or $[\mathrm{M}+\mathrm{Na}]^{+}$molecular species are reported. Purity and homogeneity of known bezohydrazide 11-19, methyl ester $\mathbf{2 a}$ and $\mathbf{2 b}$, and aldehydes $\mathbf{6 - 9}$ were confirmed by measuring their melting points, FT-IR, ${ }^{1} \mathrm{H}-\mathrm{NMR}$, and ${ }^{13} \mathrm{C}-\mathrm{NMR}$ spectra and/or HRMS and compared them with literature data. All new phenolic aroylhydrazide-hydrazones 3-5 were fully characterized. The position of hydrogen and carbon atoms in the NMR data was determined by supporting the standard dept-135 and ATP experiments and by the 2D-NMR (HMQC, HSQC, HMBC, and NOESY) experiments map analysis if measured. The spectra images of FT-IR and NMR for the following compounds are placed in Supplementary Materials as follows: Figures S1 and S2 Spectroscopic characterization of $\mathbf{1 h}$, Figure S3-S18 Spectroscopic characterization of $\mathbf{2 a}, \mathbf{2 c}, \mathbf{2 e}, \mathbf{2 g}, \mathbf{2 h}, \mathbf{2 i}$, Figure S19-S289 Spectroscopic characterization of hydrazidehydrazones 3-5, Figure S290-S293 Spectroscopic characterization of salicylic aldehydes 6 and 8, Figure S294-S348 Spectroscopic characterization of acid hydrazides 11-19.

\subsection{Synthesis of Aroylhydrazones 3-5}

To a mixture of salicylaldehyde $\mathbf{6 - 9}(2.0 \mathrm{mmol})$, and carboxylic acid hydrazide $\mathbf{1 0}-\mathbf{1 9}$ $(2.0 \mathrm{mmol})$ in $\mathrm{CH}_{3} \mathrm{OH}(5.0 \mathrm{~mL}), \mathrm{AcOH}(200 \mu \mathrm{L})$ was added at $\mathrm{RT}$ and then the resulting solution was gently refluxed during stirring. The reaction progress was monitored by TLC. Then the reaction was finished. After slow cooling to room temperature (RT) and cooled to ca. $+4{ }^{\circ} \mathrm{C}$, the reaction mixture was left in a refrigerator $\left(-24^{\circ} \mathrm{C}\right)$ overnight [31]. The crystals formed were collected by filtration to give pure products $3-5$, fully characterized by determination melting point, analysis NMR, IR, and HRMS spectra. The known compound was identified by comparing its melting points and FT-IR and/or NMR spectra with literature data and/or by HRMS determination. The error of molar mass determination by HRMS method was $\leq 0.0005 \%$.

\section{(E/Z)- $N^{\prime}$-(3-tert-butyl-2-hydroxy-5-methyl-benzylidene)acetohydrazide (3a)}

The general procedure starting from 3-tert-butyl-5-methyl-salicylic aldehyde (8) (192 mg, $1.0 \mathrm{mmol}$ [108], $\geq 90 \%$ acetic acid hydrazide (10) $(82 \mathrm{mg}, \geq 1.0 \mathrm{mmol}), \mathrm{CH}_{3} \mathrm{OH}(10 \mathrm{~mL})$, and $\mathrm{AcOH}(100 \mu \mathrm{L})$ was employed with a $2.5 \mathrm{~h}$ reaction time to obtain colorless prisms of $(E / \mathrm{Z})$ $N^{\prime}$-(3-tert-butyl-2-hydroxy-5-methyl-benzylidene)acetohydrazide (3a) $(208 \mathrm{mg}, 0.84 \mathrm{mmol}$ ) with $84 \%$ yield, which melts at $231-233^{\circ} \mathrm{C}$. Selected FT-IR (ATR): $v_{\max } 3203(\mathrm{~N}-\mathrm{H}), 3065$ $\left(\mathrm{C}_{\mathrm{Ar}}-\mathrm{H}\right), 1654(\mathrm{C}=\mathrm{O}), 1614(\mathrm{~N}-\mathrm{H}), 1591(\mathrm{C}=\mathrm{C}), 1565(\mathrm{C}=\mathrm{N}), 1428,1439,1360,1276,1239$ $\left(\mathrm{C}_{\mathrm{Ar}} \mathrm{O}\right), 1208,1123,958,860,769,710,643,569,483 \mathrm{~cm}^{-1} ;(E){ }^{1} \mathrm{H}$ NMR (400 MHz, DMSO$\left.d_{6}\right): \delta 12.06(\mathrm{~s}, 1 \mathrm{H}, \mathrm{OH}), 11.70(\mathrm{~s}, 1 \mathrm{H}, \mathrm{NHCO}), 8.21(\mathrm{~s}, 1 \mathrm{H}, \mathrm{CH}=\mathrm{N}), 7.07\left(\mathrm{~d},{ }^{4} J=1.6 \mathrm{~Hz}, 1 \mathrm{H}\right.$, 
ArH-4), 7.04 (d, ${ }^{4} J=1.6$ Hz, 1H, ArH-6), 2.23 (s, 3H, Ar-Me), 1.98 (s, 3H, Ac), 1.37 (s, 9H, t-Bu) ppm; (Z) ${ }^{1} \mathrm{H}$ NMR (400 MHz, DMSO-d $\left.)_{6}\right): \delta 11.38$ (s, 1H, NHCO), 10.96 (s, 1H, OH), $8.11(\mathrm{~s}, 1 \mathrm{H}, \mathrm{CH}=\mathrm{N}), 7.07\left(\mathrm{~d},{ }^{4} \mathrm{~J}=1.6 \mathrm{~Hz}, 1 \mathrm{H}, \mathrm{ArH}-4\right), 7.00\left(\mathrm{~d},{ }^{4} \mathrm{~J}=1.6 \mathrm{~Hz}, 1 \mathrm{H}, \mathrm{ArH}-6\right), 2.23$ (s, 3H, Ar-Me), 2.17 (s, 3H, Ac), 1.37 (s, 9H, t-Bu) ppm; (E) ${ }^{13} \mathrm{C}$ NMR (100 MHz, DMSO- $\left.d_{6}\right): \delta$ 165.23 (C=O), 154.48 (ArC-2-OH), $148.72(\mathrm{CH}=\mathrm{N}), 135.95$ (ArC-3), 129.19 (ArC-4), 129.07 (ArC-6), 126.84 (ArC-5), 117.20 (ArC-1), 34.28 (C-t-Bu), $29.15\left(3 \times \mathrm{CH}_{3}-t-\mathrm{Bu}\right), 21.15$ (Me-Ac), 20.15 (Ar-Me) ppm; (Z) ${ }^{13} \mathrm{C} \mathrm{NMR} \mathrm{(100} \mathrm{MHz,} \mathrm{DMSO-d} 6$ ): $\delta 170.62$ (C=O), 153.71 (ArC-2-OH), $146.62(\mathrm{CH}=\mathrm{N}), 136.01$ (ArC-3), 129.11 (ArC-4), 129.00 (ArC-6), 127.39 (ArC-5),

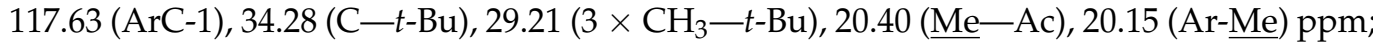
HRMS (TOF, MS, ESI) $m / z$ for $\mathrm{C}_{14} \mathrm{H}_{20} \mathrm{~N}_{2} \mathrm{O}_{2}+\mathrm{H}^{+}$calculated: 249.1598; found: 249.1598 .

2-(4-Hydroxyphenyl)- $N^{\prime}-[(E)$-(3-tert-butyl-2-hydroxy-5-methylphenyl)methylidene $]$ acetohydrazide $(3 b)$

The general procedure starting from 3-tert-butyl-5-methyl-salicylic aldehyde (8) (192 mg, $1.0 \mathrm{mmol}$ [108], (4-hydroxyphenyl)-acetic acid hydrazide (11) (166 mg, $1.0 \mathrm{mmol}), \mathrm{CH}_{3} \mathrm{OH}$ $(20 \mathrm{~mL})$, and $\mathrm{AcOH}(100 \mu \mathrm{L})$ was employed with a $2 \mathrm{~h}$ reaction time to obtain the colorless prisms of 2-(4-hydroxyphenyl)- $N^{\prime}-[(E)$-(3-tert-butyl-2-hydroxy-5-methylphenyl)methylidene] acetohydrazide (3b) $(318 \mathrm{mg}, 0.854 \mathrm{mmol})$ crystallized with one molecule of $\left.\mathrm{CH}_{3} \mathrm{OH}\right)$ with $85 \%$ yield, which melts at $242-244{ }^{\circ} \mathrm{C}\left(\mathrm{CH}_{3} \mathrm{OH}\right)$. Selected FT-IR (ATR): $v_{\max } 3236(\mathrm{~N}-\mathrm{H})$, $3064\left(\mathrm{C}_{\mathrm{Ar}}-\mathrm{H}\right), 3032\left(\mathrm{C}_{\mathrm{Ar}}-\mathrm{H}\right), 1654(\mathrm{C}=\mathrm{O}), 1612(\mathrm{~N}-\mathrm{H}), 1585(\mathrm{C}=\mathrm{C}), 1552(\mathrm{C}=\mathrm{N}), 1515,1468$, 1363, 1299, 1261 (C $\left.\mathrm{C}_{\mathrm{Ar}}-\mathrm{O}\right), 1240,1143,1022,799,769,651,642,623,521,417,435 \mathrm{~cm}^{-1} ;{ }^{1} \mathrm{H}$ NMR (400 MHz, DMSO- $\left.d_{6}\right): \delta 12.03$ (s, 1H, Ar-2-OH), 11.86 (s, 1H, NHCO), 9.30 (s, 1H, C-4-OH), $8.27(\mathrm{~s}, 1 \mathrm{H}, \mathrm{CH}=\mathrm{N}), 7.11\left(\mathrm{~d},{ }^{3} J=8.5 \mathrm{~Hz}, 2 \mathrm{H}, \mathrm{H}-2,6\right), 7.07\left(\mathrm{~d},{ }^{4} \mathrm{~J}=2.1 \mathrm{~Hz}, 1 \mathrm{H}\right.$, ArH-4), $7.04\left(\mathrm{~d},{ }^{4} J=2.1 \mathrm{~Hz}, 1 \mathrm{H}, \mathrm{ArH}-6\right), 6.72\left(\mathrm{~d},{ }^{3} \mathrm{~J}=8.5 \mathrm{~Hz}, 2 \mathrm{H}, \mathrm{H}-3,5\right), 4.12\left(\mathrm{k},{ }^{3} \mathrm{~J}=5.2 \mathrm{~Hz}\right.$,

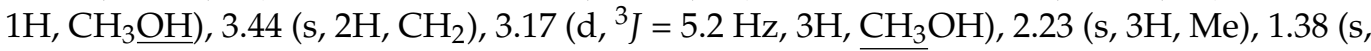
9H, $t$-Bu) ppm; ${ }^{13} \mathrm{C}$ NMR $\left(100 \mathrm{MHz}, \mathrm{DMSO}-d_{6}\right): \delta 166.77(\mathrm{C}=\mathrm{O}), 156.11(\mathrm{C}-4), 154.55(\mathrm{ArC}-$ 2-OH), 149.49 (CH=N), 136.01 (ArC-3), 129.93 (C-2, C-6), 129.33 (ArC-4), 129.12 (ArC-6), 126.90 (ArC-5), 125.33 (C-1), 117.21 (ArC-1), 115.09 (C-3, C-5), $48.55\left(\mathrm{CH}_{3} \mathrm{OH}\right), 39.43\left(\mathrm{CH}_{2}\right)$, $34.30(\mathrm{C}-t-\mathrm{Bu}), 29.15\left(3 \times \mathrm{CH}_{3}-t-\mathrm{Bu}\right), 20.18(\mathrm{Me}) \mathrm{ppm}$; HRMS (TOF, MS, ESI) $\mathrm{m} / z$ for $\mathrm{C}_{20} \mathrm{H}_{24} \mathrm{~N}_{2} \mathrm{O}_{3}+\mathrm{Na}^{+}$calculated: 363.1679; found: 363.1698 .

$N^{\prime}$-[(E)-(3-tert-butyl-2-hydroxy-5-methylphenyl)methylidene]-3-pyridohydrazide (4a)

The general procedure starting from 3-tert-butyl-5-methyl-salicylic aldehyde (8) (192 mg, $1.0 \mathrm{mmol}$ ) [108], nicotinic acid hydrazide (12) (137 mg, $1.0 \mathrm{mmol}), \mathrm{MeOH}$ (6.5 mL), and $\mathrm{AcOH}(100 \mu \mathrm{L})$ was employed with a $90 \mathrm{~min}$. reaction time and concentrated before crystallization to obtain colorless plates of $N^{\prime}-[(E)$-(3-tert-butyl-2-hydroxy-5-methylphenyl) methylidene]-3-pyridohydrazide (4a) $(291 \mathrm{mg}, 0.93 \mathrm{mmol})$ with $93 \%$ yield, which melts at 230-231 ${ }^{\circ}$ C. Selected FT-IR (ATR): $v_{\max } 3183(\mathrm{~N}-\mathrm{H}), 3011\left(\mathrm{C}_{\mathrm{Ar}}-\mathrm{H}\right), 1638(\mathrm{C}=\mathrm{O}), 1613(\mathrm{C}=\mathrm{C})$, 1590 (N-H), 1552 (C=N), 1418, 1360, 1314, 1294, 1261 (C $\left.\mathrm{Cr}_{\mathrm{Ar}} \mathrm{O}\right)$, 1236, 1207, 1167, 1093, 1028, $955,893,867,784,768,709,670,619,517,465,409 \mathrm{~cm}^{-1} ;{ }^{1} \mathrm{H}$ NMR $\left(400 \mathrm{MHz}\right.$, DMSO- $\left.d_{6}\right)$ : $\delta 12.38$ (s, 1H, NHCO), $12.15(\mathrm{~s}, 1 \mathrm{H}, \mathrm{OH}), 9.09\left(\mathrm{dd},{ }^{4} \mathrm{~J}=2.4 \mathrm{~Hz},{ }^{5} \mathrm{~J}=0.8 \mathrm{~Hz}, 1 \mathrm{H}, \mathrm{H}-2\right)$, $8.79\left(\mathrm{dd},{ }^{3} \mathrm{~J}=4.8 \mathrm{~Hz},{ }^{4} \mathrm{~J}=1.7 \mathrm{~Hz}, 1 \mathrm{H}, \mathrm{H}-4\right), 8.16(\mathrm{~s}, 1 \mathrm{H}, \mathrm{CH}=\mathrm{N}), 8.28\left(\mathrm{ddd},{ }^{3} J=7.9 \mathrm{~Hz}\right.$, $\left.{ }^{4} J=2.4 \mathrm{~Hz},{ }^{4} \mathrm{~J}=1.7 \mathrm{~Hz}, 1 \mathrm{H}, \mathrm{H}-6\right), 7.60\left(\mathrm{ddd},{ }^{3} \mathrm{~J}=7.9 \mathrm{~Hz},{ }^{3} \mathrm{~J}=4.8 \mathrm{~Hz},{ }^{5} \mathrm{~J}=0.8 \mathrm{~Hz}, 1 \mathrm{H}, \mathrm{H}-5\right)$, $7.12\left(\mathrm{~d},{ }^{4} \mathrm{~J}=1.8 \mathrm{~Hz}, 1 \mathrm{H}, \mathrm{ArH}-4\right), 7.01$ (d, $\left.{ }^{4} J=1.8 \mathrm{~Hz}, 1 \mathrm{H}, \mathrm{ArH}-6\right), 2.26$ (s, 3H, Me), 1.40 (s, 9H, $t$-Bu) ppm; ${ }^{13} \mathrm{C}$ NMR (100 MHz, DMSO- $\left.d_{6}\right): \delta 161.29$ (C=O), 154.77 (ArC-2-OH), 152.51 (C-4), $151.35(\mathrm{CH}=\mathrm{N}), 148.53$ (C-2), 136.14 (ArC-3), 135.41 (C-6), 129.71 (ArC-4), 129.33 (ArC-6), 128.37 (C-1), 127.06 (ArC-5), 123.64 (C-5), 117.13 (ArC-1), 34.34 (C-t-Bu), 29.17 $\left(3 \times \mathrm{CH}_{3}-t-\mathrm{Bu}\right), 20.16\left(\mathrm{Ar}-\mathrm{CH}_{3}\right)$ ppm; HRMS (TOF, MS, ESI) $m / z$ for $\mathrm{C}_{18} \mathrm{H}_{21} \mathrm{~N}_{3} \mathrm{O}_{2}+\mathrm{H}^{+}$ calculated: 312.1706 ; found: 312.1713 .

$N^{\prime}$-[(E)-(3-tert-butyl-2-hydroxy-5-methylphenyl)methylidene]benzohydrazide (4b)

The general procedure starting from 3-tert-butyl-5-methyl-salicylic aldehyde (8) (384 mg, $2.0 \mathrm{mmol}$ ) [108], benzoic acid hydrazide (13) (272 mg, $2.0 \mathrm{mmol}), \mathrm{CH}_{3} \mathrm{OH}$ (65 mL), and $\mathrm{AcOH}(100 \mu \mathrm{L})$ was employed with a $2 \mathrm{~h}$ reaction time to obtain colorless powder of $N^{\prime}$ [(E)-(3-tert-butyl-2-hydroxy-5-methylphenyl)methylidene]benzohydrazide (4b) (597 mg, $1.92 \mathrm{mmol}$ ) with $96 \%$, which melts at $246-248{ }^{\circ} \mathrm{C}$. Selected FT-IR (ATR): $v_{\max } 3164(\mathrm{~N}-\mathrm{H})$, $3058\left(\mathrm{C}_{\mathrm{Ar}}-\mathrm{H}\right), 3032\left(\mathrm{C}_{\mathrm{Ar}}-\mathrm{H}\right), 1635(\mathrm{C}=\mathrm{O}), 1612(\mathrm{~N}-\mathrm{H}), 1578(\mathrm{C}=\mathrm{C}), 1561(\mathrm{C}=\mathrm{N}), 1440,1364$, 
1317, $1264\left(\mathrm{C}_{\mathrm{Ar}}-\mathrm{O}\right) 1285,1207$ ( $\left.\mathrm{C}_{\mathrm{Ar}}-\mathrm{O}\right), 1170,1088,968,889,860,768,690,672,571,512,423$ $\mathrm{cm}^{-1} ;{ }^{1} \mathrm{H}$ NMR (400 MHz, DMSO- $\left.d_{6}\right): \delta 12.45$ (s, 1H, OH), 12.22 (s, 1H, NHCO), 8.53 (s, $1 \mathrm{H}, \mathrm{CH}=\mathrm{N}), 7.95\left(\mathrm{dd},{ }^{3} \mathrm{~J}=7.3 \mathrm{~Hz},{ }^{4} \mathrm{~J}=1.3 \mathrm{~Hz}, 2 \mathrm{H}, \mathrm{H}-2,6\right), 7.63\left(\mathrm{tt},{ }^{3} \mathrm{~J}=7.3 \mathrm{~Hz},{ }^{4} \mathrm{~J}=1.3 \mathrm{~Hz}\right.$, $1 \mathrm{H}, \mathrm{H}-4), 7.56\left(\mathrm{dd},{ }^{3} J=7.3 \mathrm{~Hz},{ }^{3} J=7.3 \mathrm{~Hz}, 2 \mathrm{H}, \mathrm{H}-3,5\right), 7.10\left(\mathrm{~d},{ }^{4} \mathrm{~J}=1.8 \mathrm{~Hz}, 1 \mathrm{H}, \mathrm{ArH}-4\right), 7.07$ $\left(\mathrm{d},{ }^{4} \mathrm{~J}=1.8 \mathrm{~Hz}, 1 \mathrm{H}, \mathrm{ArH}-6\right), 2.26$ (s, 3H, Me), 1.40 (s, 9H, $t$-Bu) ppm; ${ }^{13} \mathrm{C} \mathrm{NMR}(100 \mathrm{MHz}$, DMSO-d $\left.d_{6}\right): \delta 162.67(\mathrm{C}=\mathrm{O}), 154.71(\mathrm{ArC}-2), 150.75(\mathrm{CH}=\mathrm{N}), 136.09(\mathrm{ArC}-3), 132.50(\mathrm{C}-1)$, 132.02 (C-4), 129.48 (ArC-4), 129.18 (ArC-6), 128.53 (C-3, C-5), 127.57 (C-2, C-6), 126.96 (ArC-5), 117.26 (ArC-1), 34.32 (C-t-Bu), 29.17 (3 $\left.\times \mathrm{CH}_{3}-t-\mathrm{Bu}\right), 20.17$ (Ar-Me) ppm; HRMS (TOF, MS, ESI) $m / z$ for $\mathrm{C}_{19} \mathrm{H}_{22} \mathrm{~N}_{2} \mathrm{O}_{2}+\mathrm{H}^{+}$calculated: 311.1754; found: 311.1771 .

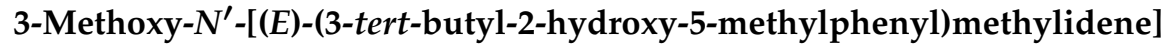
benzohydrazide $(4 \mathrm{c})$

The general procedure starting from 3-tert-butyl-5-methyl-salicylic aldehyde (8) (192 mg, $1.0 \mathrm{mmol}$ ) [108], 3-methoxybenzoic acid hydrazide (14) (166 mg, $1.0 \mathrm{mmol}), \mathrm{CH}_{3} \mathrm{OH}(45 \mathrm{~mL})$, and $\mathrm{AcOH}(100 \mu \mathrm{L})$ was employed with a $4.5 \mathrm{~h}$ reaction time to obtain of 3-methoxy- $N^{\prime}-$ [(E)-(3-tert-butyl-2-hydroxy-5-methylphenyl)methylidene]benzohydrazide (4c) (317 mg, $0.931 \mathrm{mmol}$ ) with $93 \%$ yield, as a pale yellow crystals, as watt, which melts at $238-240{ }^{\circ} \mathrm{C}$. Selected FT-IR (ATR): $v_{\max } 3173(\mathrm{~N}-\mathrm{H}), 3064\left(\mathrm{C}_{\mathrm{Ar}}-\mathrm{H}\right), 3008\left(\mathrm{C}_{\mathrm{Ar}}-\mathrm{H}\right), 1633(\mathrm{C}=\mathrm{O}), 1584(\mathrm{~N}-\mathrm{H})$, $1560(\mathrm{C}=\mathrm{N}), 1486,1462,1427,1364,1318,1295,1279,1241\left(\mathrm{C}_{\mathrm{Ar}}-\mathrm{O}\right), 1140,1083,1044,970$, 861, 811, 755, 714, 693, 570, 493, $466 \mathrm{~cm}^{-1} ;{ }^{1} \mathrm{H}$ NMR (400 MHz, DMSO-d $\left.d_{6}\right): \delta 12.23(\mathrm{~s}, 1 \mathrm{H}$, $\mathrm{NH}), 12.17(\mathrm{~s}, 1 \mathrm{H}, \mathrm{OH}), 8.52(\mathrm{~s}, 1 \mathrm{H}, \mathrm{CH}=\mathrm{N}), 7.53\left(\mathrm{ddd},{ }^{3} \mathrm{~J}=7.8 \mathrm{~Hz},{ }^{4} \mathrm{~J}=1.5 \mathrm{~Hz},{ }^{4} \mathrm{~J}=1.1 \mathrm{~Hz}\right.$, $1 \mathrm{H}, \mathrm{H}-6), 7.48\left(\mathrm{dd},{ }^{4} J=2.5 \mathrm{~Hz},{ }^{4} J=1.5 \mathrm{~Hz}, 1 \mathrm{H}, \mathrm{H}-2\right), 7.47\left(\mathrm{dd},{ }^{3} J=8.0 \mathrm{~Hz},{ }^{3} J=7.8 \mathrm{~Hz}, 1 \mathrm{H}\right.$, H-5), $7.19\left(\mathrm{ddd},{ }^{3} J=8.0 \mathrm{~Hz},{ }^{4} J=2.5 \mathrm{~Hz},{ }^{4} J=1.1 \mathrm{~Hz}, 1 \mathrm{H}, \mathrm{H}-4\right), 7.11\left(\mathrm{~d},{ }^{4} \mathrm{~J}=1.7 \mathrm{~Hz}, 1 \mathrm{H}\right.$, ArH-4), 7.06 (d, $\left.{ }^{4} J=1.7 \mathrm{~Hz}, 1 \mathrm{H}, \mathrm{ArH}-6\right), 3.84$ (s, 1H, OMe), 2.26 (s, 3H, Me), 1.40 (s, 9H, $t$-Bu) ppm; ${ }^{13} \mathrm{C}$ NMR (100 MHz, DMSO- $\left.d_{6}\right): \delta 162.41(\mathrm{C}=\mathrm{O}), 159.20(\mathrm{C}-3), 154.73(\mathrm{ArC}-$ 2-OH), $150.84(\mathrm{CH}=\mathrm{N}), 136.10$ (ArC-3), 133.88 (C-1), 129.73 (C-5), 129.49 (ArC-4), 129.18 (ArC-6), 126.97 (ArC-5), 119.76 (C-6), 117.65 (C-4), 117.27 (ArC-1), 112.88 (C-2), 55.30 (OMe), $34.33(\mathrm{C}-t-\mathrm{Bu}), 29.17\left(3 \times \mathrm{CH}_{3}-t-\mathrm{Bu}\right), 20.18(\mathrm{Me}) \mathrm{ppm}$; HRMS (TOF, MS, ESI) $m / z$ for $\mathrm{C}_{20} \mathrm{H}_{24} \mathrm{~N}_{2} \mathrm{O}_{3}+\mathrm{H}^{+}$calculated: 341.1860; found: 341.1852 .

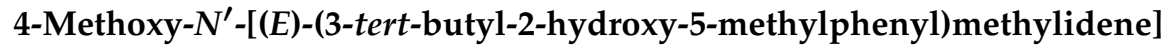
benzohydrazide $(4 \mathrm{~d})$

The general procedure starting from 3-tert-butyl-5-methyl-salicylic aldehyde (8) [108] (192 mg, $1.0 \mathrm{mmol})$, 4-methoxybenzoic acid hydrazide (15) (166 mg, $1.0 \mathrm{mmol}), \mathrm{CH}_{3} \mathrm{OH}$ $(20 \mathrm{~mL})$, and $\mathrm{AcOH}(100 \mu \mathrm{L})$ was employed with a $2 \mathrm{~h}$ reaction time and concentrated by slow distillation before crystallization to obtain the 4-methoxy- $N^{\prime}-[(E)$-(3-tert-butyl2-hydroxy-5-methylphenyl)methylidene]benzohydrazide (4d) (276 mg, $0.81 \mathrm{mmol})$ as colorless needles with $81 \%$ yield, which melts at $243-244{ }^{\circ} \mathrm{C}$. Selected FT-IR (ATR): $v_{\max }$ $3165(\mathrm{~N}-\mathrm{H}), 3008\left(\mathrm{C}_{\mathrm{Ar}}-\mathrm{H}\right), 1636(\mathrm{C}=\mathrm{O}), 1605(\mathrm{~N}-\mathrm{H}), 1585(\mathrm{C}=\mathrm{C}), 1537(\mathrm{C}=\mathrm{N}), 1508,1440$, 1432, 1358, 1286, 1235 (C $\left.\mathrm{Ar}_{\mathrm{Ar}} \mathrm{O}\right), 1207,1183,1173,1088,1029,971,896,838,765,689,614$, $500,465 \mathrm{~cm}^{-1} ;{ }^{1} \mathrm{H}$ NMR (400 MHz, DMSO-d 6 ): $\delta 12.28(\mathrm{~s}, 1 \mathrm{H}, \mathrm{OH}), 12.08(\mathrm{~s}, 1 \mathrm{H}, \mathrm{NHCO})$, $8.51(\mathrm{~s}, 1 \mathrm{H}, \mathrm{CH}=\mathrm{N}), 7.94\left(\mathrm{~d},{ }^{3} \mathrm{~J}=8.9 \mathrm{~Hz}, 2 \mathrm{H}, \mathrm{H}-2,6\right), 7.09\left(\mathrm{~d},{ }^{3} \mathrm{~J}=8.9 \mathrm{~Hz}, 2 \mathrm{H}, \mathrm{H}-3,5\right), 7.09$ $\left(\mathrm{d},{ }^{4} J=1.6 \mathrm{~Hz}, 1 \mathrm{H}, \mathrm{ArH}-4\right), 7.06\left(\mathrm{~d},{ }^{4} J=1.6 \mathrm{~Hz}, 1 \mathrm{H}, \mathrm{ArH}-6\right), 3.84$ (s, 1H, OMe), 2.25 (s, 3H, Me), 1.39 (s, 9H, $t$-Bu) ppm; ${ }^{13} \mathrm{C} \mathrm{NMR} \mathrm{(100} \mathrm{MHz,} \mathrm{DMSO-d} 6$ ): $\delta 162.20$ (C-4), 162.06 $(\mathrm{C}=\mathrm{O}), 154.65(\mathrm{ArC}-2-\mathrm{OH}), 150.09(\mathrm{CH}=\mathrm{N}), 136.04$ (ArC-3), 129.52 (C-2, C-6), 129.30 (ArC-4), 129.06 (ArC-6), 126.90 (ArC-5), 124.48 (C-1), 117.36 (ArC-1), 113.76 (C-3, C-5), 55.39 (OMe), $34.31(\mathrm{C}-t-\mathrm{Bu}), 29.17\left(3 \times \mathrm{CH}_{3}-t-\mathrm{Bu}\right), 20.18(\mathrm{Me}) \mathrm{ppm}$; HRMS (TOF, MS, ESI) $m / z$ for $\mathrm{C}_{20} \mathrm{H}_{24} \mathrm{~N}_{2} \mathrm{O}_{3}+\mathrm{H}^{+}$calculated: 341.1860; found: 341.1870.

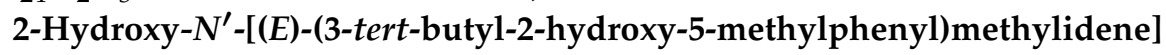
benzohydrazide (4e)

The general procedure starting from 3-tert-butyl-5-methyl-salicylic aldehyde (8) (192 mg, $1.0 \mathrm{mmol}$ [108], 2-hydroxybenzoic acid hydrazide (16) (152 mg, $1.0 \mathrm{mmol}), \mathrm{CH}_{3} \mathrm{OH}(15 \mathrm{~mL})$, and $\mathrm{AcOH}(100 \mu \mathrm{L})$ was employed with a $2 \mathrm{~h}$ reaction time and concentrated by slow distillation before crystallization to obtain the 2-hydroxy- $N^{\prime}-[(E)-(3-$ tert-butyl-2-hydroxy-5methylphenyl)methylidene]benzohydrazide (4e) $(309 \mathrm{mg}, 0.95 \mathrm{mmol})$ as a colorless prisms with $95 \%$ yield, which melts at $252-253{ }^{\circ} \mathrm{C}$. Selected FT-IR (ATR): $v_{\max } 3250$ (N-H), 3033 
$\left(\mathrm{C}_{\mathrm{Ar}}-\mathrm{H}\right), 2999\left(\mathrm{C}_{\mathrm{Ar}}-\mathrm{H}\right), 1637(\mathrm{C}=\mathrm{O}), 1615(\mathrm{~N}-\mathrm{H}), 1581(\mathrm{C}=\mathrm{C}), 1560(\mathrm{C}=\mathrm{N})$, 1456, 1436, 1361, $1319,1308,1235\left(\mathrm{C}_{\mathrm{Ar}}-\mathrm{O}\right), 1204,1158,1098,942,904,786,768,743,719,617,530,469,447$, $442 \mathrm{~cm}^{-1} ;{ }^{1} \mathrm{H}$ NMR $\left(400 \mathrm{MHz}, \mathrm{DMSO}-d_{6}\right): \delta 12.17(\mathrm{~s}, 1 \mathrm{H}, \mathrm{ArOH}), 12.12(\mathrm{~s}, 1 \mathrm{H}, \mathrm{NHCO}$ or $\mathrm{OH}), 11.67(\mathrm{~s}, 1 \mathrm{H}, \mathrm{NHCO}$ or $\mathrm{OH}), 8.56(\mathrm{~s}, 1 \mathrm{H}, \mathrm{CH}=\mathrm{N}), 7.88\left(\mathrm{dd},{ }^{3} \mathrm{~J}=7.9 \mathrm{~Hz},{ }^{4} \mathrm{~J}=1.6 \mathrm{~Hz}\right.$, $1 \mathrm{H}, \mathrm{H}-6), 7.46\left(\mathrm{ddd},{ }^{3} J=8.4 \mathrm{~Hz},{ }^{3} J=7.2 \mathrm{~Hz},{ }^{4} J=1.6 \mathrm{~Hz}, 1 \mathrm{H}, \mathrm{H}-4\right), 7.11\left(\mathrm{~d},{ }^{4} J=1.7 \mathrm{~Hz}, 1 \mathrm{H}\right.$, ArH-4), $7.08\left(\mathrm{~d},{ }^{4} J=1.7 \mathrm{~Hz}, 1 \mathrm{H}\right.$, ArH-6), $7.00\left(\mathrm{dd},{ }^{3} J=8.4 \mathrm{~Hz},{ }^{4} J=1.0 \mathrm{~Hz}, 1 \mathrm{H}, \mathrm{H}-3\right), 6.98$ $\left(\mathrm{ddd},{ }^{3} J=7.8 \mathrm{~Hz},{ }^{3} J=7.2 \mathrm{~Hz},{ }^{4} J=1.0 \mathrm{~Hz}, 1 \mathrm{H}, \mathrm{H}-5\right), 2.26$ (s, 3H, Me), 1.40 (s, 9H, $t-\mathrm{Bu}$ ) ppm; ${ }^{13} \mathrm{C}$ NMR (100 MHz, DMSO-d 6 ): $\delta 164.15(\mathrm{C}=\mathrm{O}), 158.70(\mathrm{C}-2), 154.76(\mathrm{ArC}-2-\mathrm{OH}), 151.50$ $(\mathrm{CH}=\mathrm{N}), 136.14$ (ArC-3), 133.94 (C-4), 129.68 (ArC-4), 129.30 (ArC-6), 128.61 (C-6), 127.02 (ArC-5), 119.02 (C-5), 117.20 (C-3, ArC-1), 115.61 (C-1), 34.33 (C-t-Bu), $29.17\left(3 \times \mathrm{CH}_{3}-\right.$ $t$-Bu), $20.18\left(\mathrm{CH}_{3}\right)$ ppm; HRMS (TOF, MS, ESI): $m / z$ for $\mathrm{C}_{19} \mathrm{H}_{22} \mathrm{~N}_{2} \mathrm{O}_{3}+\mathrm{H}^{+}$calculated: 327.1703; found: 327.1701.

3,5-Dihydroxy- $N^{\prime}-[(E)$-(3-tert-butyl-2-hydroxy-5-methylphenyl)methylidene] benzohydrazide $(\mathbf{4 f})$

The general procedure starting from 3-tert-butyl-5-methyl-salicylic aldehyde (8) (192 mg, $1.0 \mathrm{mmol}$ [108], 3,5-dihydroxybenzoic acid hydrazide (17) (168 mg, $1.0 \mathrm{mmol}), \mathrm{CH}_{3} \mathrm{OH}$ $(5.0 \mathrm{~mL})$, and $\mathrm{AcOH}(100 \mu \mathrm{L})$ was employed with a $2 \mathrm{~h}$ reaction time, to obtain colorless powder of 3,5-dihydroxy- $N^{\prime}$-[(E)-(3-tert-butyl-2-hydroxy-5-methylphenyl)methylidene] benzohydrazide (4f) $(285 \mathrm{mg}, 0.83 \mathrm{mmol})$ with $83 \%$ yield, which melts at $246{ }^{\circ} \mathrm{C}\left(\mathrm{CH}_{3} \mathrm{OH}\right)$ with decompositions. Selected FT-IR (ATR): $v_{\max } 3189$ (br., N-H), $3046(\mathrm{C}-\mathrm{H}), 1643(\mathrm{C}=\mathrm{O})$, $1583(\mathrm{~N}-\mathrm{H}, \mathrm{C}=\mathrm{C}), 1556(\mathrm{C}=\mathrm{N}), 1435,1363,1341,1314,1265$ (br., $\left.\mathrm{C}_{\mathrm{Ar}}-\mathrm{O}\right), 1208,1164,1001$, $863,798,681,518,427 \mathrm{~cm}^{-1} ;{ }^{1} \mathrm{H}$ NMR $\left(400 \mathrm{MHz}, \mathrm{DMSO}-d_{6}\right): \delta 12.25$ (s, $\left.1 \mathrm{H}, \mathrm{Ar}-2-\mathrm{OH}\right)$, $12.04(\mathrm{~s}, 1 \mathrm{H}, \mathrm{CONH}), 9.63(\mathrm{~s}, 2 \mathrm{H}, 3-\mathrm{OH}, 5-\mathrm{OH}), 8.50(\mathrm{~s}, 1 \mathrm{H}, \mathrm{CH}=\mathrm{N}), 7.09\left(\mathrm{~d},{ }^{4} J=1.4 \mathrm{~Hz}, 1 \mathrm{H}\right.$, ArH-4), $7.03\left(\mathrm{~d},{ }^{4} J=1.4 \mathrm{~Hz}, 1 \mathrm{H}, \mathrm{ArH}-6\right), 6.78\left(\mathrm{~d},{ }^{4} J=2.1 \mathrm{~Hz}, 2 \mathrm{H}, \mathrm{H}-2,6\right), 6.45\left(\mathrm{t},{ }^{4} J=2.1 \mathrm{~Hz}\right.$, $1 \mathrm{H}, \mathrm{H}-4), 2.25$ (s, 3H, Me), 1.39 (s, 9H, $t$-Bu) ppm; $\left.{ }^{13} \mathrm{C} \mathrm{NMR} \mathrm{(100} \mathrm{MHz,} \mathrm{DMSO-} d_{6}\right): \delta 162.86$ $(\mathrm{C}=\mathrm{O}), 158.46(\mathrm{C}-3, \mathrm{C}-5), 154.71(\mathrm{ArC}-2-\mathrm{OH}), 150.54(\mathrm{CH}=\mathrm{N}), 136.09$ (ArC-3), $134.52(\mathrm{C}-1)$, 129.41 (ArC-4), 129.15 (ArC-6), 126.95 (ArC-5), 117.33 (ArC-1), 105.90 (C-4), 105.71 (C-2, C-6), $34.34(\mathrm{C}-t-\mathrm{Bu}), 29.19\left(3 \times \mathrm{CH}_{3}-t\right.$-Bu), 20.19 (Me) ppm; HRMS (TOF, MS, ESI): $m / z$ for $\mathrm{C}_{19} \mathrm{H}_{22} \mathrm{~N}_{2} \mathrm{O}_{4}+\mathrm{H}^{+}$calculated: 343.1652; found: 343.1650 .

\section{2-Hydroxy- $N^{\prime}-[(E)$-(3,5-di-tert-butyl-2-hydroxyphenyl)methylidene $]$} benzohydrazide $(4 \mathrm{~g})$

The general procedure starting from 3,5-di-tert-butyl-salicylic aldehyde (9) $(234 \mathrm{mg}$, $1.0 \mathrm{mmol}$ [ [108], 2-hydroxybenzoic acid hydrazide (16) (152 mg, $1.0 \mathrm{mmol}), \mathrm{CH}_{3} \mathrm{OH}(3.8 \mathrm{~mL})$, and $\mathrm{AcOH}(100 \mu \mathrm{L})$ was employed with a $4 \mathrm{~h}$ reaction time, to obtain 2-hydroxy- $N^{\prime}-[(E)-(3,5-$ di-tert-butyl-2-hydroxyphenyl)methylidene]benzohydrazide $(4 \mathrm{~g})(359 \mathrm{mg}, 0.97 \mathrm{mmol})$ with $97 \%$ yield as colorless powder, which melts at $233-235{ }^{\circ} \mathrm{C}\left(\mathrm{CH}_{3} \mathrm{OH}\right)$ (m.p. $218-222{ }^{\circ} \mathrm{C}$ [89]), (m.p. 230-232 ${ }^{\circ} \mathrm{C}$ [90]). Selected FT-IR (ATR): $v_{\max } 3238$ (br., N-H, O-H), 3078 (C-H), 1636 $(\mathrm{C}=\mathrm{O}), 1611(\mathrm{C}=\mathrm{C}), 1584(\mathrm{~N}-\mathrm{H}), 1554(\mathrm{C}=\mathrm{N}), 1486,1461,1436,1359,1329,1302,1269,1247$ $\left(\mathrm{C}_{\mathrm{Ar}} \mathrm{O}\right), 1215,1173,825,770,745,714,665,534,505,428 \mathrm{~cm}^{-1}$; ${ }^{1} \mathrm{H}$ NMR (600 MHz, DMSO$\left.d_{6}\right): \delta 12.20(\mathrm{~s}, 1 \mathrm{H}, \mathrm{Ar}-2-\mathrm{OH}), 12.08(\mathrm{~s}, \mathrm{br}, 1 \mathrm{H}, \mathrm{NHCO}$ or $2-\mathrm{OH}), 11.67$ (s, br, $1 \mathrm{H}, \mathrm{NHCO}$ or 2-OH), $8.63(\mathrm{~s}, 1 \mathrm{H}, \mathrm{CH}=\mathrm{N}), 7.89\left(\mathrm{dd},{ }^{3} \mathrm{~J}=7.8 \mathrm{~Hz},{ }^{4} J=1.5 \mathrm{~Hz}, 1 \mathrm{H}, \mathrm{H}-6\right), 7.46\left(\mathrm{ddd},{ }^{3} \mathrm{~J}=8.3 \mathrm{~Hz}\right.$, $\left.J=7.7 \mathrm{~Hz},{ }^{4} J=1.5 \mathrm{~Hz}, 1 \mathrm{H}, \mathrm{H}-4\right), 7.32\left(\mathrm{~d},{ }^{4} J=2.3 \mathrm{~Hz}, 1 \mathrm{H}, \mathrm{ArH}-4\right), 7.25\left(\mathrm{~d},{ }^{4} J=2.3 \mathrm{~Hz}, 1 \mathrm{H}\right.$, ArH-6), $7.01\left(\mathrm{~d},{ }^{3} J=8.3 \mathrm{~Hz}, 1 \mathrm{H}, \mathrm{H}-3\right), 6.98\left(\mathrm{dd},{ }^{3} J=7.8 \mathrm{~Hz},{ }^{3} J=7.4 \mathrm{~Hz}, 1 \mathrm{H}, \mathrm{H}-5\right), 1.41(\mathrm{~s}$, 9H, Ar-3-t-Bu), 1.28 (s, 9H, Ar-5-t-Bu) ppm; ${ }^{1} \mathrm{H}$ NMR (400 MHz, DMSO- $\left.d_{6}\right): \delta 12.21$ (s, $1 \mathrm{H}$, Ar-2-OH), 12.08 (s, br, 1H, NHCO or 2-OH), 11.67 (s, br, 1H, NHCO or 2-OH), $8.63(\mathrm{~s}, 1 \mathrm{H}$, $\mathrm{CH}=\mathrm{N}), 7.89\left(\mathrm{~d},{ }^{3} \mathrm{~J}=7.4 \mathrm{~Hz}, 1 \mathrm{H}, \mathrm{H}-6\right), 7.46\left(\mathrm{dd},{ }^{3} \mathrm{~J}=7.5 \mathrm{~Hz},{ }^{3} \mathrm{~J}=7.3 \mathrm{~Hz}, 1 \mathrm{H}, \mathrm{H}-4\right), 7.32(\mathrm{~d}$, $\left.{ }^{4} J=1.7 \mathrm{~Hz}, 1 \mathrm{H}, \mathrm{ArH}-4\right), 7.25\left(\mathrm{~d},{ }^{4} J=1.7 \mathrm{~Hz}, 1 \mathrm{H}, \mathrm{ArH}-6\right), 7.01\left(\mathrm{~d},{ }^{3} J=7.3 \mathrm{~Hz}, 1 \mathrm{H}, \mathrm{H}-3\right), 6.98$ $\left(\mathrm{dd},{ }^{3} J=7.5 \mathrm{~Hz},{ }^{3} J=7.4 \mathrm{~Hz}, 1 \mathrm{H}, \mathrm{H}-5\right), 1.41$ (s, 9H, Ar-3-t-Bu), 1.28 (s, 9H, Ar-5-t-Bu) ppm; ${ }^{13} \mathrm{C}$ NMR $\left(100 \mathrm{MHz}, \mathrm{DMSO}-d_{6}\right): \delta 163.96(\mathrm{C}=\mathrm{O}), 158.51$ (C-2), $154.70(\mathrm{ArC}-2-\mathrm{OH}), 151.92$ $(\mathrm{CH}=\mathrm{N}), 140.39$ (ArC-5), 135.62 (ArC-3), 133.90 (C-4), 128.79 (C-6), 125.85 (ArC-6), 125.70 (ArC-4), 119.08 (C-5), 117.18 (C-3), 116.86 (ArC-1), 115.79 (C-1), 34.59 (C-ArC-3-t-Bu), $33.82(\mathrm{C}-\mathrm{ArC}-5-t-\mathrm{Bu}), 31.22\left(3 \times \mathrm{CH}_{3}-\mathrm{ArC}-5-t-\mathrm{Bu}\right), 29.22\left(3 \times \mathrm{CH}_{3}-\mathrm{ArC}-3-t-\mathrm{Bu}\right) \mathrm{ppm}$; HRMS (TOF, MS, ESI) $m / z$ for $\mathrm{C}_{22} \mathrm{H}_{28} \mathrm{~N}_{2} \mathrm{O}_{3}+\mathrm{H}^{+}$: calculated 369.2173; found: 369.2186. 


\section{3-Hydroxy- $N^{\prime}-[(E)$-(3,5-di-tert-butyl-2-hydroxyphenyl)methylidene $]$ benzohydrazide $(4 \mathrm{~h})$}

The general procedure starting from 3,5-di-tert-butyl-salicylic aldehyde (9) $(234 \mathrm{mg}, 1.0$ mmol) [108], 3-hydroxybenzoic acid hydrazide (18) (152 mg, $1.0 \mathrm{mmol}), \mathrm{CH}_{3} \mathrm{OH}(5.0 \mathrm{~mL})$, and $\mathrm{AcOH}(100 \mu \mathrm{L})$ was employed with a $4 \mathrm{~h}$ reaction time, to obtain 3-hydroxy- $N^{\prime}-[(E)$ (3,5-di-tert-butyl-2-hydroxyphenyl)methylidene]benzohydrazide (4h) $(359 \mathrm{mg}, 0.97 \mathrm{mmol})$ with $97 \%$ yield as white wool, which melts at $273-274{ }^{\circ} \mathrm{C}\left(\mathrm{CH}_{3} \mathrm{OH}\right)$. Selected FT-IR (ATR): $v_{\max } 3201$ (br., N-H, O-H), $3064(\mathrm{C}-\mathrm{H}), 1638(\mathrm{C}=\mathrm{O}), 1611(\mathrm{~N}-\mathrm{H}), 1567(\mathrm{C}=\mathrm{N})$, 1480, 1435, 1358, 1318, 1302, 1270, 1251 ( $\left.\mathrm{C}_{\mathrm{Ar}}-\mathrm{O}\right), 1201,1172,1133,1086,832,769,695,683,642,587$, 533, $441 \mathrm{~cm}^{-1} ;{ }^{1} \mathrm{H}$ NMR $\left(600 \mathrm{MHz}, \mathrm{DMSO}-d_{6}\right): \delta 12.31(\mathrm{~s}, 1 \mathrm{H}, \mathrm{Ar}-2-\mathrm{OH}), 12.12(\mathrm{~s}, 1 \mathrm{H}$, $\mathrm{NHCO}), 9.83(\mathrm{~s}, 1 \mathrm{H}, 3-\mathrm{OH}), 8.57(\mathrm{~s}, 1 \mathrm{H}, \mathrm{CH}=\mathrm{N}), 7.36\left(\mathrm{~d},{ }^{3} \mathrm{~J}=8.1 \mathrm{~Hz}, 1 \mathrm{H}, \mathrm{H}-6\right), 7.34(\mathrm{dd}$, $\left.{ }^{3} J=8.1 \mathrm{~Hz},{ }^{3} \mathrm{~J}=7.3 \mathrm{~Hz}, 1 \mathrm{H}, \mathrm{H}-5\right), 7.33$ (s, $\left.1 \mathrm{H}, \mathrm{H}-2\right), 7.31\left(\mathrm{~d},{ }^{4} J=2.3 \mathrm{~Hz}, 1 \mathrm{H}\right.$, ArH-4), 7.20 $\left(\mathrm{d},{ }^{4} J=2.3 \mathrm{~Hz}, 1 \mathrm{H}, \mathrm{ArH}-6\right), 7.01\left(\mathrm{ddd},{ }^{3} J=7.3 \mathrm{~Hz},{ }^{4} J=2.1 \mathrm{~Hz},{ }^{4} J=2.1 \mathrm{~Hz}, 1 \mathrm{H}, \mathrm{H}-4\right), 1.41$ (s, 9H, Ar-3-t-Bu), 1.28 (s, 9H, Ar-5-t-Bu) ppm; ${ }^{13} \mathrm{C}$ NMR (100 MHz, DMSO- $d_{6}$ ): $\delta 162.76$ $(\mathrm{C}=\mathrm{O}), 157.44(\mathrm{C}-3-\mathrm{OH}), 154.67(\mathrm{ArC}-2-\mathrm{OH}), 151.10(\mathrm{CH}=\mathrm{N}), 140.32(\mathrm{ArC}-5), 135.58(\mathrm{ArC}-3)$, 133.93 (C-1), 129.61 (C-5), 125.66 (ArC-4 or ArC-6), 125.47 (ArC-4 or ArC-6), 118.97 (C-4), 118.07 (C-6), 116.94 (ArC-1), 114.45 (C-2), 34.59 (C-ArC-3-t-Bu), 33.82 (C-ArC-5-t-Bu), $31.23\left(3 \times \mathrm{CH}_{3}-\mathrm{ArC}-5-t-\mathrm{Bu}\right), 29.23\left(3 \times \mathrm{CH}_{3}-\mathrm{ArC}-3-t-\mathrm{Bu}\right) \mathrm{ppm}$; HRMS (TOF, MS, ESI) $m / z$ for $\mathrm{C}_{22} \mathrm{H}_{28} \mathrm{~N}_{2} \mathrm{O}_{3}+\mathrm{H}^{+}$: calculated 369.2173; found: 369.2183 .

3,5-Dihydroxy- $N^{\prime}-[(E)$-(3,5-di-tert-butyl-2-hydroxyphenyl)methylidene $]$ benzohydrazide $(4 \mathrm{i})$

The general procedure starting from 3,5-di-tert-butyl-salicylic aldehyde (9) $(117 \mathrm{mg}$, $0.5 \mathrm{mmol}$ [108], 3,5-dihydroxybenzoic acid hydrazide (17) $(84 \mathrm{mg}, 0.5 \mathrm{mmol}), \mathrm{CH}_{3} \mathrm{OH}$ $(3.0 \mathrm{~mL})$, and $\mathrm{AcOH}(50 \mu \mathrm{L})$ was employed with a $2 \mathrm{~h}$ reaction time, to obtain 3,5dihydroxy- $N^{\prime}$-[(E)-(3,5-di-tert-butyl-2-hydroxyphenyl)methylidene]benzohydrazide (4i) (190 mg, $0.494 \mathrm{mmol}$ ) with $99 \%$ yield as colorless powder, which melts at $266^{\circ} \mathrm{C}\left(\mathrm{CH}_{3} \mathrm{OH}\right)$ with decompositions. Selected FT-IR (ATR): $v_{\max } 3228$ (br., N-H), $3076\left(\mathrm{C}_{\mathrm{Ar}}-\mathrm{H}\right), 1629(\mathrm{C}=\mathrm{C})$, $1599(\mathrm{C}=\mathrm{O}), 1583(\mathrm{~N}-\mathrm{H}), 1549(\mathrm{C}=\mathrm{N}), 1464,1435,1358,1300,1269,1249,1234\left(\mathrm{C}_{\mathrm{Ar}}-\mathrm{O}\right)$, 1172, 1162, 1138, 1007, 855, 810, 751, 714, 609, 542, 514, $433 \mathrm{~cm}^{-1} ;{ }^{1} \mathrm{H}$ NMR $(400 \mathrm{MHz}$, DMSO- $\left.d_{6}\right): \delta 12.32(\mathrm{~s}, 1 \mathrm{H}, \mathrm{Ar}-2-\mathrm{OH}), 12.05(\mathrm{~s}, 1 \mathrm{H}, \mathrm{CONH}), 9.65(\mathrm{~s}, 2 \mathrm{H}, 3-\mathrm{OH}, 5-\mathrm{OH}), 8.55$ $(\mathrm{s}, 1 \mathrm{H}, \mathrm{CH}=\mathrm{N}), 7.30\left(\mathrm{~d},{ }^{4} \mathrm{~J}=2.2 \mathrm{~Hz}, 1 \mathrm{H}, \mathrm{ArH}-4\right), 7.18\left(\mathrm{~d},{ }^{4} \mathrm{~J}=2.2 \mathrm{~Hz}, 1 \mathrm{H}, \mathrm{ArH}-6\right), 6.78$ $\left(\mathrm{d},{ }^{4} J=2.0 \mathrm{~Hz}, 2 \mathrm{H}, \mathrm{H}-2,6\right), 6.45\left(\mathrm{t},{ }^{4} \mathrm{~J}=2.0 \mathrm{~Hz}, 1 \mathrm{H}, \mathrm{H}-4\right), 1.41(\mathrm{~s}, 9 \mathrm{H}, \mathrm{Ar}-3-t-\mathrm{Bu}), 1.28(\mathrm{~s}$, 9H, Ar-5-t-Bu) ppm; ${ }^{13} \mathrm{C}$ NMR (100 MHz, DMSO- $\left.d_{6}\right): \delta 162.96$ (C=O), $158.48(\mathrm{C}-3, \mathrm{C}-5)$, 154.69 (ArC-2-OH), $150.98(\mathrm{CH}=\mathrm{N}), 140.33$ (ArC-5), 135.60 (ArC-3), 134.58 (C-1), 125.66 (ArC-4), 126.46 (ArC-6), 116.99 (ArC-1), 105.92 (C-4), 105.75 (C-2, C-6), 34.62 (C-3-t-Bu), $33.85(\mathrm{C}-5-t-\mathrm{Bu}), 31.27\left(3 \times \mathrm{CH}_{3}-5-t-\mathrm{Bu}\right), 29.25\left(3 \times \mathrm{CH}_{3}-3-t-\mathrm{Bu}\right)$ ppm; HRMS (TOF, MS, ESI): $m / z$ for $\mathrm{C}_{22} \mathrm{H}_{28} \mathrm{~N}_{2} \mathrm{O}_{4}+\mathrm{H}^{+}$calculated: 385.2122; found: 385.2120;HRMS (TOF, MS, ESI): $m / z$ for $\mathrm{C}_{22} \mathrm{H}_{28} \mathrm{~N}_{2} \mathrm{O}_{4}+\mathrm{Na}^{+}$calculated: 407.1941; found: 407.1948.

2-Hydroxy- $N^{\prime}-[(E)$-(3-tert-butyl-2-hydroxyphenyl)methylidene $]$ benzohydrazide (4j)

The general procedure starting from 3-tert-butyl-salicylic aldehyde (7) $(190 \mathrm{mg}$, $1.0 \mathrm{mmol}$ [ [108], 2-hydroxybenzohydrazide (16) (152 mg, $1.0 \mathrm{mmol}), \mathrm{CH}_{3} \mathrm{OH}(3.0 \mathrm{~mL})$, and $\mathrm{AcOH}(100 \mu \mathrm{L})$ was employed with a $3.5 \mathrm{~h}$ reaction time and crystallization in open vessel to obtain pale 2-hydroxy- $N^{\prime}$-[(E)-(3-tert-butyl-2-hydroxyphenyl)methylidene $]$ benzohydrazide (4j) (306 $\mathrm{mg}, 0.98 \mathrm{mmol}$ ) as a with $98 \%$ yield, which melts at $218-220{ }^{\circ} \mathrm{C}$. Selected FT-IR (ATR): $v_{\max } 3248$ (br., N-H), $3064\left(\mathrm{C}_{\mathrm{Ar}}-\mathrm{H}\right), 1630(\mathrm{C}=\mathrm{O}), 1610(\mathrm{~N}-\mathrm{H}), 1583(\mathrm{C}=\mathrm{C}), 1552(\mathrm{C}=\mathrm{N})$, 1455, 1429 (C-N), 1356, 1305, 1261, 1231 ( $\left.\mathrm{C}_{\mathrm{Ar}}-\mathrm{O}\right), 1198$ 1158, 1146, 1100, 1086, 942, 902, 852, 798, 737, 691, 662, 590, 565, 524, $422 \mathrm{~cm}^{-1} ;{ }^{1} \mathrm{H}$ NMR (600 MHz, DMSO- $\left.d_{6}\right): \delta 12.40$ (s, $1 \mathrm{H}$, $\mathrm{ArOH}), 12.12(\mathrm{~s}, 1 \mathrm{H}), 11.66(\mathrm{~s}, 1 \mathrm{H}), 8.62(\mathrm{~s}, 1 \mathrm{H}, \mathrm{CH}=\mathrm{N}), 7.88\left(\mathrm{~d},{ }^{3} \mathrm{~J}=7.9 \mathrm{~Hz}, 1 \mathrm{H}, \mathrm{H}-6\right), 7.46$ $\left(\mathrm{dd},{ }^{3} \mathrm{~J}=7.9 \mathrm{~Hz},{ }^{3} \mathrm{~J}=7.5 \mathrm{~Hz}, 1 \mathrm{H}, \mathrm{H}-4\right), 7.31\left(\mathrm{~d},{ }^{3} \mathrm{~J}=7.6 \mathrm{~Hz}, 1 \mathrm{H}, \mathrm{ArH}-4\right), 7.30\left(\mathrm{~d},{ }^{3} J=7.6 \mathrm{~Hz}\right.$, $1 \mathrm{H}, \mathrm{ArH}-6), 7.01\left(\mathrm{~d},{ }^{3} \mathrm{~J}=7.9 \mathrm{~Hz}, 1 \mathrm{H}, \mathrm{H}-3\right), 6.98\left(\mathrm{dd},{ }^{3} \mathrm{~J}=7.9 \mathrm{~Hz},{ }^{3} \mathrm{~J}=7.5 \mathrm{~Hz}, 1 \mathrm{H}, \mathrm{H}-5\right)$, $6.89\left(\mathrm{dd},{ }^{3} \mathrm{~J}=7.6 \mathrm{~Hz},{ }^{3} \mathrm{~J}=7.6 \mathrm{~Hz}, 1 \mathrm{H}, \mathrm{ArH}-5\right), 1.41(\mathrm{~s}, 9 \mathrm{H}, t-\mathrm{Bu}) \mathrm{ppm} ;{ }^{1} \mathrm{H}$ NMR $(400 \mathrm{MHz}$, DMSO- $\left.d_{6}\right): \delta 12.41(\mathrm{~s}, 1 \mathrm{H}, \mathrm{ArOH}), 12.13(\mathrm{~s}, 1 \mathrm{H}), 11.68(\mathrm{~s}, 1 \mathrm{H}), 8.63(\mathrm{~s}, 1 \mathrm{H}, \mathrm{CH}=\mathrm{N}), 7.89$ $\left(\mathrm{dd},{ }^{3} J=7.9 \mathrm{~Hz},{ }^{4} J=1.3 \mathrm{~Hz}, 1 \mathrm{H}, \mathrm{H}-6\right), 7.46\left(\mathrm{ddd},{ }^{3} J=7.7 \mathrm{~Hz},{ }^{3} J=7.5 \mathrm{~Hz}, 1 \mathrm{H}, \mathrm{H}-4\right), 7.30(\mathrm{~d}$, $\left.{ }^{3} J=7.7 \mathrm{~Hz}, 1 \mathrm{H}, \mathrm{ArH}-4\right), 7.30\left(\mathrm{~d},{ }^{3} \mathrm{~J}=7.6 \mathrm{~Hz}, 1 \mathrm{H}, \mathrm{ArH}-6\right), 7.01\left(\mathrm{~d},{ }^{3} \mathrm{~J}=7.7 \mathrm{~Hz}, 1 \mathrm{H}, \mathrm{H}-3\right), 6.98$ 
$\left(\mathrm{dd},{ }^{3} J=7.9 \mathrm{~Hz},{ }^{3} J=7.5 \mathrm{~Hz}, 1 \mathrm{H}, \mathrm{H}-5\right), 6.89\left(\mathrm{dd},{ }^{3} J=7.7 \mathrm{~Hz},{ }^{3} J=7.6 \mathrm{~Hz}, 1 \mathrm{H}\right.$, ArH-5), 1.41 $(\mathrm{s}, 9 \mathrm{H}, t-\mathrm{Bu}) \mathrm{ppm} ;{ }^{13} \mathrm{C}$ NMR $\left(100 \mathrm{MHz}, \mathrm{DMSO}-d_{6}\right): \delta 164.14(\mathrm{C}=\mathrm{O}), 158.69(\mathrm{C}-2), 156.95$ $(\mathrm{ArC}-2-\mathrm{OH}), 151.52(\mathrm{CH}=\mathrm{N}), 136.34$ (ArC-3), 133.97 (C-4), 129.61 (ArC-6), 128.67 (C-6, ArC4), 119.06 (C-5), 118.75 (ArC-5), 117.53 (ArC-1), 117.22 (C-3), 115.61 (C-1), 34.43 (C-t-Bu), $29.15\left(3 \times \mathrm{CH}_{3}-t\right.$-Bu) ppm; HRMS (TOF, MS, ESI): $m / z$ for $\mathrm{C}_{18} \mathrm{H}_{20} \mathrm{~N}_{2} \mathrm{O}_{3}+\mathrm{H}^{+}$calculated: 313.1547; found: 313.1558 .

3-Hydroxy- $N^{\prime}$-[(E)-(3-tert-butyl-2-hydroxyphenyl)methylidene]benzohydrazide (4k)

The general procedure starting from 3-tert-butyl-salicylic aldehyde (7) (95 mg, $0.50 \mathrm{mmol})$ [108], 3-hydroxybenzoic acid hydrazide (18) $(76 \mathrm{mg}, 0.50 \mathrm{mmol}), \mathrm{CH}_{3} \mathrm{OH}$ $(3.0 \mathrm{~mL})$, and $\mathrm{AcOH}(100 \mu \mathrm{L})$ was employed with a $3.0 \mathrm{~h}$ reaction time and crystallized with addition of water $(0.7 \mathrm{~mL})$ before decolorization with charcoal to obtain the 3-hydroxy- $N^{\prime}$ [(E)-(3-tert-butyl-2-hydroxyphenyl)methylidene]benzohydrazide (4k) (142 mg, $0.455 \mathrm{mmol})$ as a pale solid with $91 \%$ yield, which melts at $225-228^{\circ} \mathrm{C}$. Selected FT-IR (ATR): $v_{\max } 3227$ (br., N-H), 3068 ( $\left.\mathrm{C}_{\mathrm{Ar}}-\mathrm{H}\right), 1648$ (C=O), 1590 (N-H, C=C), $1567(\mathrm{C}=\mathrm{N}), 1456,1429,1362,1320$, 1259,1240 (C $\left.\mathrm{Ar}_{-\mathrm{O}}\right), 1197,1143,1084,846,745,701,685,595,494 \mathrm{~cm}^{-1}$; ${ }^{1} \mathrm{H}$ NMR $(600 \mathrm{MHz}$, DMSO-d $\left.)_{6}\right): \delta 12.49(\mathrm{~s}, 1 \mathrm{H}, \mathrm{Ar}-2-\mathrm{OH}), 12.15$ (s, 1H, NHCO), 9.83 (s, 1H, 3-OH), 8.57 (s, 1H, $\mathrm{CH}=\mathrm{N}), 7.38(\mathrm{~d}, J=7.6 \mathrm{~Hz}, 1 \mathrm{H}, \mathrm{H}-6), 7.35\left(\mathrm{dd},{ }^{3} \mathrm{~J}=7.6 \mathrm{~Hz},{ }^{3} \mathrm{~J}=7.6 \mathrm{~Hz}, 1 \mathrm{H}, \mathrm{H}-5\right), 7.34(\mathrm{~s}$, $1 \mathrm{H}, \mathrm{H}-2), 7.29\left(\mathrm{dd},{ }^{3} J=7.7 \mathrm{~Hz},{ }^{4} J=1.1 \mathrm{~Hz}, 1 \mathrm{H}, \mathrm{ArH}-4\right), 7.27\left(\mathrm{dd},{ }^{3} J=7.7 \mathrm{~Hz},{ }^{4} J=1.1 \mathrm{~Hz}\right.$, $1 \mathrm{H}$, ArH-6), 7.01 (ddd, $\left.{ }^{3} J=7.6 \mathrm{~Hz},{ }^{4} J=2.3 \mathrm{~Hz},{ }^{4} J=1.4 \mathrm{~Hz}, 1 \mathrm{H}, \mathrm{H}-4\right), 6.88\left(\mathrm{dd},{ }^{3} J=7.7 \mathrm{~Hz}\right.$, $\left.{ }^{3} J=7.6 \mathrm{~Hz}, 1 \mathrm{H}, \mathrm{ArH}-5\right), 1.41$ (s, 9H, $t$-Bu) ppm; ${ }^{13} \mathrm{C}$ NMR (100 MHz, DMSO-d $\left.d_{6}\right): \delta 162.73$ $(\mathrm{C}=\mathrm{O}), 157.46(\mathrm{C}-3-\mathrm{OH}), 156.90(\mathrm{ArC}-2-\mathrm{OH}), 150.68(\mathrm{CH}=\mathrm{N}), 136.30(\mathrm{ArC}-3), 133.84(\mathrm{C}-1)$, 129.63 (C-5), 129.46 (ArC-6), 128.44 (ArC-4), 119.02 (C-4), 118.69 (ArC-5), 118.06 (C-6), 117.62 (ArC-1), 114.46 (C-2), $34.43(\mathrm{C}-t-\mathrm{Bu}), 29.17\left(3 \times \mathrm{CH}_{3}-t-\mathrm{Bu}\right) \mathrm{ppm}$; HRMS (TOF, MS, ESI): $m / z$ for $\mathrm{C}_{18} \mathrm{H}_{20} \mathrm{~N}_{2} \mathrm{O}_{3}+\mathrm{H}^{+}$calculated: 313.1547; found: 313.1547 .

\section{3,5-Dihydroxy- $N^{\prime}-[(E)-(3-$ tert-butyl-2-hydroxyphenyl)methylidene $]$} benzohydrazide (41)

The general procedure starting from 3-tert-butyl-salicylic aldehyde (7) (95 mg, $0.50 \mathrm{mmol}$ [108] 3,5-dihydroxybenzoic acid hydrazide (17) $(84 \mathrm{mg}, 0.50 \mathrm{mmol}), \mathrm{CH}_{3} \mathrm{OH}$ $(3.0 \mathrm{~mL})$, and $\mathrm{AcOH}(50 \mu \mathrm{L})$ was employed with a $3.0 \mathrm{~h}$ reaction time and crystallized with addition of water $(1.0 \mathrm{~mL})$ before concentration at reduced pressure to obtain the 3,5dihydroxy- $N^{\prime}$-[(E)-(3-tert-butyl-2-hydroxyphenyl)methylidene]benzohydrazide (41) (138 mg, $0.42 \mathrm{mmol}$ ) as a pale solid with $84 \%$ yield, which melts at $217-220{ }^{\circ} \mathrm{C}$. Selected FT-IR (ATR): $v_{\max } 3208$ (br., N-H), $3070\left(\mathrm{C}_{\mathrm{Ar}}-\mathrm{H}\right), 1591(\mathrm{C}=\mathrm{O}, \mathrm{N}-\mathrm{H}), 1557(\mathrm{C}=\mathrm{N}), 1429,1337,1302,1262$ (br., $\left.\mathrm{C}_{\mathrm{Ar}}-\mathrm{O}\right), 1200,1162,1003,806,792,746,674,623,557,521,471,441 \mathrm{~cm}^{-1},{ }^{1} \mathrm{H}$ NMR $(400 \mathrm{MHz}$, DMSO- $d_{6}$ ): $\delta 12.46$ (s, 1H, Ar-2-OH), 12.03 (s, 1H, NHCO), 9.61 (s, 2H, 3-OH, 5-OH), 8.51 (s, $1 \mathrm{H}, \mathrm{CH}=\mathrm{N}), 7.25\left(\mathrm{dd},{ }^{3} \mathrm{~J}=7.7 \mathrm{~Hz},{ }^{4} \mathrm{~J}=1.3 \mathrm{~Hz}, 1 \mathrm{H}, \mathrm{ArH}-4\right), 7.21\left(\mathrm{dd},{ }^{3} \mathrm{~J}=7.7 \mathrm{~Hz},{ }^{4} \mathrm{~J}=1.3 \mathrm{~Hz}\right.$, $1 \mathrm{H}, \mathrm{ArH}-6), 6.83\left(\mathrm{dd},{ }^{3} J=7.7 \mathrm{~Hz},{ }^{3} J=7.7 \mathrm{~Hz}, 1 \mathrm{H}, \mathrm{ArH}-5\right), 6.74\left(\mathrm{~d},{ }^{4} J=2.1 \mathrm{~Hz}, 2 \mathrm{H}, \mathrm{H}-2,6\right)$, $6.42\left(\mathrm{t},{ }^{4} \mathrm{~J}=2.1 \mathrm{~Hz}, 1 \mathrm{H}, \mathrm{H}-4\right), 1.36(\mathrm{~s}, 9 \mathrm{H}, t-\mathrm{Bu}) \mathrm{ppm} ;{ }^{13} \mathrm{C}$ NMR $\left(100 \mathrm{MHz}, \mathrm{DMSO}-d_{6}\right): \delta$ $162.93(\mathrm{C}=\mathrm{O}), 158.50(\mathrm{C}-3-\mathrm{OH}, \mathrm{C}-5-\mathrm{OH}), 156.92(\mathrm{ArC}-2-\mathrm{OH}), 150.58(\mathrm{CH}=\mathrm{N}), 136.33(\mathrm{ArC}-3)$, 134.49 (C-1), 129.45 (ArC-6), 128.43 (ArC-4), 118.71 (ArC-5), 117.67 (ArC-1), 105.98 (C-4), 105.75 (C-2, C-6), $34.46(\mathrm{C}-t-\mathrm{Bu}), 29.19\left(3 \times \mathrm{CH}_{3}-t-\mathrm{Bu}\right) \mathrm{ppm}$; HRMS (TOF, MS, ESI): $m / z$ for $\mathrm{C}_{18} \mathrm{H}_{20} \mathrm{~N}_{2} \mathrm{O}_{4}+\mathrm{H}^{+}$calculated: 329.1496; found: 329.1503 .

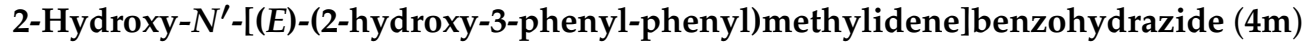

The general procedure starting from 3-phenyl-salicylic aldehyde (6) (149 mg, $0.75 \mathrm{mmol}$ ) [108], 2-hydroxybenzohydrazide (16) (114 mg, $0.75 \mathrm{mmol}), \mathrm{CH}_{3} \mathrm{OH}$ (30 mL), and $\mathrm{AcOH}(75 \mu \mathrm{L})$ was employed with a $3.5 \mathrm{~h}$ reaction time and crystallization with concentration to obtain a white solid the 2-hydroxy- $N^{\prime}-[(E)-(2-$ hydroxy-3-phenyl-phenyl)methylidene $]$ benzohydrazide $(4 \mathrm{~m})(206 \mathrm{mg}, 0.62 \mathrm{mmol})$ with $83 \%$ yield, which melts in $224-227{ }^{\circ} \mathrm{C}$. Selected FT-IR (ATR): $v_{\max } 3231$ (br., N-H), 3100-3000 (br., $\left.\mathrm{C}_{\mathrm{Ar}}-\mathrm{H}\right), 1601$ (C=O), 1580 (N-H), 1559 (C=N), 1453, 1436, 1371, 1307, 1231 (br., $\left.\mathrm{C}_{\text {Ar }}-\mathrm{O}\right)$, 1153, 1071, 892, 747, 696, 664, 625, 582, 568, 532, $469 \mathrm{~cm}^{-1} ;{ }^{1} \mathrm{H}$ NMR (600 MHz, DMSO-d 6 ): $\delta 12.26$ (s, 1H, Ar-2-OH), 12.18 (s, 1H, OH or NH), $11.65(\mathrm{~s}, 1 \mathrm{H}, \mathrm{OH}$ or $\mathrm{NH}), 8.71(\mathrm{~s}, 1 \mathrm{H}, \mathrm{CH}=\mathrm{N}), 7.88\left(\mathrm{dd},{ }^{3} \mathrm{~J}=7.9 \mathrm{~Hz}\right.$, $\left.{ }^{4} J=1.6 \mathrm{~Hz}, 1 \mathrm{H}, \mathrm{H}-6\right), 7.61\left(\mathrm{dd},{ }^{3} J=8.1 \mathrm{~Hz},{ }^{4} J=1.2 \mathrm{~Hz}, 2 \mathrm{H}, \mathrm{PhH}-2,6\right), 7.48\left(\mathrm{dd},{ }^{3} J=7.6 \mathrm{~Hz}\right.$, $\left.{ }^{4} J=1.5 \mathrm{~Hz}, 1 \mathrm{H}, \mathrm{ArH}-6\right), 7.47\left(\mathrm{ddd}^{3} J=8.3 \mathrm{~Hz},{ }^{3} J=7.2 \mathrm{~Hz},{ }^{4} J=1.6 \mathrm{~Hz}, 1 \mathrm{H}, \mathrm{H}-4\right), 7.45(\mathrm{ddd}$, 
$\left.{ }^{3} J=8.1 \mathrm{~Hz},{ }^{3} J=7.4 \mathrm{~Hz}, 2 \mathrm{H}, \mathrm{PhH}-3,5\right), 7.41\left(\mathrm{dd},{ }^{3} J=7.5 \mathrm{~Hz},{ }^{4} J=1.5 \mathrm{~Hz}, 1 \mathrm{H}, \mathrm{ArH}-4\right), 7.36(\mathrm{tt}$, $\left.{ }^{3} J=7.4 \mathrm{~Hz},{ }^{4} J=1.2 \mathrm{~Hz}, 1 \mathrm{H}, \mathrm{PhH}-4\right), 7.06\left(\mathrm{dd},{ }^{3} J=7.6 \mathrm{~Hz},{ }^{3} \mathrm{~J}=7.5 \mathrm{~Hz}, 1 \mathrm{H}, \mathrm{ArH}-5\right), 7.01(\mathrm{dd}$, $\left.{ }^{3} J=8.3 \mathrm{~Hz},{ }^{4} J=1.0 \mathrm{~Hz}, 1 \mathrm{H}, \mathrm{H}-3\right), 6.98\left(\mathrm{ddd},{ }^{3} J=7.9 \mathrm{~Hz},{ }^{3} \mathrm{~J}=7.2 \mathrm{~Hz},{ }^{4} J=1.0 \mathrm{~Hz}, 1 \mathrm{H}, \mathrm{H}-5\right)$ ppm; ${ }^{13} \mathrm{C}$ NMR (100 MHz, DMSO- $\left.d_{6}\right): \delta 164.19$ (C=O), 158.65 (C-2-OH), $154.96(\mathrm{ArC}-2-\mathrm{OH})$, $150.75(\mathrm{CH}=\mathrm{N}), 137.36$ (PhC-1), 134.31 (C-4), 132.38 (ArC-4), 130.66 (ArC-6), 129.15 (PhC-2, PhC-6), 128.82 (ArC-3), 128.75 (C-6), 128.00 (PhC-3, PhC-5), 126.99 (PhC-4), 119.53 (ArC-5), 119.08 (C-5), 118.09 (ArC-1), 117.21 (C-3), 115.65 (C-1) ppm; HRMS (TOF, MS, ESI): $m / z$ for $\mathrm{C}_{20} \mathrm{H}_{16} \mathrm{~N}_{2} \mathrm{O}_{3}+\mathrm{H}^{+}$calculated: 333.1234; found: 333.1237.

3-Hydroxy- $N^{\prime}-[(E)$-(2-hydroxy-3-phenyl-phenyl)methylidene $]$ benzohydrazide (4n) The general procedure starting from 3-phenyl-salicylic aldehyde (6) $(99 \mathrm{mg}$, $0.50 \mathrm{mmol}$ [108], 3-hydroxybenzohydrazide (18) $(76 \mathrm{mg}, 0.50 \mathrm{mmol}), \mathrm{CH}_{3} \mathrm{OH}(3.0 \mathrm{~mL})$, and $\mathrm{AcOH}(50 \mu \mathrm{L})$ was employed with a $2.0 \mathrm{~h}$ reaction time to obtain the 3-hydroxy- $\mathrm{N}^{\prime}$ [(E)-(2-hydroxy-3-phenyl-phenyl)methylidene]benzohydrazide (4n) $(157 \mathrm{mg}, 0.47 \mathrm{mmol})$ as a white solid with $94 \%$ yield, which melts at $207-20{ }^{\circ} \mathrm{C}$. Selected FT-IR (ATR): $v_{\max }$ 3227 (br., N-H), 3056 (br., $\left.\mathrm{C}_{\mathrm{Ar}}-\mathrm{H}\right), 1651(\mathrm{C}=\mathrm{O}), 1592(\mathrm{~N}-\mathrm{H}), 1527(\mathrm{C}=\mathrm{N})$, 1448, 1428, 1352, 1284, 1227 (br., $\mathrm{C}_{\mathrm{Ar}} \mathrm{-O}$ ), 1137, 1071, 830, 755, 706, 691, 680, 642, 580, 549, $534 \mathrm{~cm}^{-1} ;{ }^{1} \mathrm{H}$ NMR $\left(600 \mathrm{MHz}, \mathrm{DMSO}-d_{6}\right): \delta 12.37$ (s, 1H, Ar-2-OH), 12.23 (s, 1H, NHCO), $9.84(\mathrm{~s}, 1 \mathrm{H}, 3-\mathrm{OH})$, $8.65(\mathrm{~s}, 1 \mathrm{H}, \mathrm{CH}=\mathrm{N}), 7.60\left(\mathrm{~d},{ }^{3} \mathrm{~J}=7.3 \mathrm{~Hz}, 2 \mathrm{H}, \mathrm{PhH}-2,6\right), 7.45\left(\mathrm{~d},{ }^{3} J=7.6 \mathrm{~Hz}, 1 \mathrm{H}, \mathrm{ArH}-6\right), 7.44$ $\left(\mathrm{dd},{ }^{3} J=7.9 \mathrm{~Hz},{ }^{3} J=7.3 \mathrm{~Hz}, 2 \mathrm{H}, \mathrm{PhH}-3.5\right), 7.40\left(\mathrm{dd},{ }^{3} J=7.6 \mathrm{~Hz},{ }^{4} J=1.4 \mathrm{~Hz}, 1 \mathrm{H}, \mathrm{ArH}-4\right)$, $7.37\left(\mathrm{t},{ }^{3} \mathrm{~J}=7.9 \mathrm{~Hz}, 1 \mathrm{H}, \mathrm{PhH}-4\right), 7.32-7.37$ (m, 3H, H-2, H-5, H-6), $7.04\left(\mathrm{dd},{ }^{3} \mathrm{~J}=7.6 \mathrm{~Hz}\right.$, $\left.{ }^{3} J=7.6 \mathrm{~Hz}, 1 \mathrm{H}, \mathrm{ArH}-5\right), 7.02\left(\mathrm{ddd},{ }^{3} J=7.8 \mathrm{~Hz},{ }^{4} J=2.3 \mathrm{~Hz},{ }^{4} J=1.2 \mathrm{~Hz}, 1 \mathrm{H}, \mathrm{H}-4\right) \mathrm{ppm}$; ${ }^{13} \mathrm{C}$ NMR $\left(100 \mathrm{MHz}, \mathrm{DMSO}-d_{6}\right): \delta 162.79$ (C=O), 157.47 (C-3), 154.94 (ArC-2-OH), 149.93 $(\mathrm{CH}=\mathrm{N}), 137.42$ (PhC-1), 133.79 (C-1), 132.18 (ArC-4), 130.54 (ArC-6), 129.65 (C-5), 129.16 (PhC-2, PhC-6), 128.77 (ArC-3), 128.01 (PhC-3, PhC-5), 126.98 (PhC-4), 119.47 (ArC-5), 119.07 (C-4), 118.17 (ArC-1), 118.11 (C-6), 114.49 (C-2) ppm; HRMS (TOF, MS, ESI): $m / z$ for $\mathrm{C}_{20} \mathrm{H}_{16} \mathrm{~N}_{2} \mathrm{O}_{3}+\mathrm{H}^{+}$calculated: 333.1234; found: 333.1241 .

3,5-Dihydroxy- $N^{\prime}-[(E)$-(2-hydroxy-3-phenyl-phenyl)methylidene] benzohydrazide (4o)

The general procedure starting from 3-phenyl-salicylic aldehyde (6) $(99 \mathrm{mg}$, $0.50 \mathrm{mmol})$ [108], 3,5-dihydroxybenzohydrazide (17) $(84 \mathrm{mg}, 0.50 \mathrm{mmol}), \mathrm{CH}_{3} \mathrm{OH}(3.0 \mathrm{~mL})$, and $\mathrm{AcOH}(50 \mu \mathrm{L})$ was employed with a $4.0 \mathrm{~h}$ reaction time to obtain the 3,5-dihydroxy- $\mathrm{N}^{\prime}$ [(E)-(2-hydroxy-3-phenyl-phenyl)methylidene]benzohydrazide (4o) $(159 \mathrm{mg}, 0.456 \mathrm{mmol})$ as a white solid with $91 \%$ yield, which melts at $241-243{ }^{\circ} \mathrm{C}$. Selected FT-IR (ATR): $v_{\max } 3234$ (br., N-H), 3056 (br., $\left.\mathrm{C}_{\mathrm{Ar}}-\mathrm{H}\right), 1655(\mathrm{C}=\mathrm{O}), 1592(\mathrm{~N}-\mathrm{H}), 1544(\mathrm{C}=\mathrm{N})$, 1449, 1428, 1337, 1301, 1277,1254 (br., $\left.\mathrm{C}_{\mathrm{Ar}}-\mathrm{O}\right), 1159,1141,1000,800,754,696,676,680,642,580,549,534 \mathrm{~cm}^{-1} ;{ }^{1} \mathrm{H}$ NMR (600 MHz, DMSO- $\left.d_{6}\right): \delta 12.38$ (s, 1H, Ar-2-OH), $12.14(\mathrm{~s}, 1 \mathrm{H}, \mathrm{NHCO}), 9.65$ (s, 2H, $3-\mathrm{OH}, 5-\mathrm{OH}), 8.63(\mathrm{~s}, 1 \mathrm{H}, \mathrm{CH}=\mathrm{N}), 7.60\left(\mathrm{~d},{ }^{3} \mathrm{~J}=7.2 \mathrm{~Hz}, 2 \mathrm{H}, \mathrm{PhH}-2,6\right), 7.44\left(\mathrm{dd},{ }^{3} J=7.4 \mathrm{~Hz}\right.$, $\left.{ }^{3} J=7.2 \mathrm{~Hz}, 2 \mathrm{H}, \mathrm{PhH}-3.5\right), 7.43\left(\mathrm{dd},{ }^{3} J=7.7 \mathrm{~Hz},{ }^{4} J=1.3 \mathrm{~Hz}, 1 \mathrm{H}, \mathrm{ArH}\right), 7.39\left(\mathrm{dd},{ }^{3} J=7.5 \mathrm{~Hz}\right.$, $\left.{ }^{4} J=1.3 \mathrm{~Hz}, 1 \mathrm{H}, \mathrm{ArH}\right), 7.35\left(\mathrm{t},{ }^{3} \mathrm{~J}=7.4 \mathrm{~Hz}, 1 \mathrm{H}, \mathrm{PhH}-4\right), 7.04\left(\mathrm{dd},{ }^{3} \mathrm{~J}=7.7 \mathrm{~Hz},{ }^{3} J=7.5 \mathrm{~Hz}\right.$, $1 \mathrm{H}, \mathrm{ArH}-5), 6.79\left(\mathrm{~d},{ }^{4} \mathrm{~J}=2.1 \mathrm{~Hz}, 2 \mathrm{H}, \mathrm{H}-2,6\right), 6.46\left(\mathrm{t},{ }^{4} J=2.1 \mathrm{~Hz}, 1 \mathrm{H}, \mathrm{H}-4\right) \mathrm{ppm} ;{ }^{13} \mathrm{C}$ NMR $\left(100 \mathrm{MHz}, \mathrm{DMSO}-d_{6}\right): \delta 162.97(\mathrm{C}=\mathrm{O}), 158.51(\mathrm{C}-3, \mathrm{C}-5), 154.95(\mathrm{ArC}-2-\mathrm{OH}), 149.83(\mathrm{CH}=\mathrm{N})$, 137.45 (PhC-1), 134.44 (C-1), 132.16 (ArC-4), 130.54 (ArC-6), 129.19 (PhC-2, PhC-6), 128.78 (ArC-3), 128.04 (PhC-3, PhC-5), 127.01 (PhC-4), 119.49 (ArC-5), 118.21 (ArC-1), 106.02 (C-4), 105.78 (C-2, C-6) ppm; HRMS (TOF, MS, ESI): $m / z$ for $\mathrm{C}_{20} \mathrm{H}_{16} \mathrm{~N}_{2} \mathrm{O}_{4}+\mathrm{H}^{+}$calculated: 349.1183; found: 349.1197 .

$N^{\prime}$-[(E)-(3-tert-butyl-2-hydroxy-5-methylphenyl)methylidene]-2-(1-hydroxynaphtho) hydrazide (5a)

The general procedure starting from 3-tert-butyl-5-methyl-salicylic aldehyde (8) (192 mg, $1.0 \mathrm{mmol}$ [108], 1-hydroxy-2-naphthohydrazide (19) (202 mg, $1.0 \mathrm{mmol})$ [109], $\mathrm{CH}_{3} \mathrm{OH}$ $(65 \mathrm{~mL})$, and $\mathrm{AcOH}(100 \mu \mathrm{L})$ was employed with a $6 \mathrm{~h}$ reaction time and concentrated by slow distillation before crystallization to obtain the colorless prisms of $N^{\prime}-[(E)$-(3-tert-butyl2-hydroxy-5-methylphenyl)methylidene]-2-(1-hydroxynaphtho)hydrazide (5a) (345 mg, $0.916 \mathrm{mmol}$ ) with $92 \%$ yield, which melts at $215-217^{\circ} \mathrm{C}$. Selected FT-IR (ATR): $v_{\max } 3379$ (O-H), $3233(\mathrm{~N}-\mathrm{H}), 3062\left(\mathrm{C}_{\mathrm{Ar}}-\mathrm{H}\right), 1616(\mathrm{C}=\mathrm{O}), 1581(\mathrm{~N}-\mathrm{H}), 1532(\mathrm{C}=\mathrm{N})$, 1467, 1388, 1356, 
1310, 1275, 1250 ( $\left.\mathrm{C}_{\mathrm{Ar}} \mathrm{-O}\right), 1207$ ( $\left.\mathrm{C}_{\mathrm{Ar}} \mathrm{-O}\right), 1175,1155,813,788,757,707,566,496,423 \mathrm{~cm}^{-1}$; ${ }^{1} \mathrm{H}$ NMR $\left(400 \mathrm{MHz}, \mathrm{DMSO}-d_{6}\right): \delta 13.85(\mathrm{~s}, 1 \mathrm{H}, \mathrm{OH}), 12.50(\mathrm{~s}, 1 \mathrm{H}, \mathrm{OH}), 12.19(\mathrm{~s}, 1 \mathrm{H}, \mathrm{NHCO})$, $8.65(\mathrm{~s}, 1 \mathrm{H}, \mathrm{CH}=\mathrm{N}), 8.32\left(\mathrm{~d},{ }^{3} \mathrm{~J}=8.2 \mathrm{~Hz}, 1 \mathrm{H}, \mathrm{H}-4\right), 7.97\left(\mathrm{~d},{ }^{3} \mathrm{~J}=8.9 \mathrm{~Hz}, 1 \mathrm{H}, \mathrm{H}-8\right), 7.92(\mathrm{~d}$, $\left.{ }^{3} J=8.2 \mathrm{~Hz}, 1 \mathrm{H}, \mathrm{H}-3\right), 7.69\left(\mathrm{dd},{ }^{3} J=8.8 \mathrm{~Hz},{ }^{3} J=6.1 \mathrm{~Hz}, 1 \mathrm{H}, \mathrm{H}-6\right), 7.60\left(\mathrm{dd},{ }^{3} J=8.9 \mathrm{~Hz}\right.$, $\left.{ }^{3} J=6.1 \mathrm{~Hz}, 1 \mathrm{H}, \mathrm{H}-7\right), 7.49\left(\mathrm{~d},{ }^{3} \mathrm{~J}=8.9 \mathrm{~Hz}, 1 \mathrm{H}, \mathrm{H}-5\right), 7.14(\mathrm{~s}, 2 \mathrm{H}, \mathrm{ArH}-4, \mathrm{ArH}-6), 2.27(\mathrm{~s}, 3 \mathrm{H}$, $\left.\mathrm{CH}_{3}\right), 1.42(\mathrm{~s}, 9 \mathrm{H}, t-\mathrm{Bu}) \mathrm{ppm} ;{ }^{13} \mathrm{C}$ NMR (100 MHz, DMSO- $\left.d_{6}\right): \delta 166.58(\mathrm{C}=\mathrm{O}), 156.15(\mathrm{C})$, $154.88(\mathrm{C}), 152.27(\mathrm{CH}=\mathrm{N}), 136.23(\mathrm{C}), 135.97(\mathrm{C}), 129.94(\mathrm{CH}), 129.50(\mathrm{CH}), 129.34(\mathrm{CH})$, $127.51(\mathrm{C}), 126.08(\mathrm{CH}), 124.52(\mathrm{C}), 123.04(\mathrm{CH}), 122.22(\mathrm{CH}), 118.05(\mathrm{CH}), 117.14(\mathrm{C}), 115.77$ (C), $34.36(\mathrm{C}), 29.19\left(3 \times \mathrm{CH}_{3}-t-\mathrm{Bu}\right), 20.18\left(\mathrm{CH}_{3}\right) \mathrm{ppm}$; HRMS (TOF, MS, ESI) $\mathrm{m} / z$ for $\mathrm{C}_{23} \mathrm{H}_{24} \mathrm{~N}_{2} \mathrm{O}_{3}+\mathrm{H}^{+}$: calculated 377.1860; found: 377.1858.

$N^{\prime}$-[(E)-(3-tert-butyl-2-hydroxy-3-phenyl-phenyl)methylidene]-2-(1-hydroxynaphtho) hydrazide $(5 b)$

The general procedure starting from 3-phenyl-salicylic aldehyde (9) (198 mg, $1.0 \mathrm{mmol}$ ) [108], 1-hydroxy-2-naphthohydrazide (19) (202 mg, $1.0 \mathrm{mmol})$ [109], $\mathrm{CH}_{3} \mathrm{OH}$ $(100 \mathrm{~mL})$, and $\mathrm{AcOH}(100 \mu \mathrm{L})$ was employed with a $3 \mathrm{~h}$ reaction time to obtain the $N^{\prime}-[(E)-$ (2-hydroxy-3-phenylphenyl)methylidene]-2-(1-hydroxynaphtho)hydrazide (5b) (313 mg, $0.819 \mathrm{mmol}$ ) as pale powders with $82 \%$ yield, which melts at $226-228{ }^{\circ} \mathrm{C}$. Selected FT-IR (ATR): $v_{\max } 3373(\mathrm{O}-\mathrm{H}), 3100-3000\left(\mathrm{~N}-\mathrm{H}, \mathrm{C}_{\mathrm{Ar}}-\mathrm{H}\right), 1628(\mathrm{C}=\mathrm{O}), 1600(\mathrm{~N}-\mathrm{H}), 1573(\mathrm{C}=\mathrm{C})$, $1532(\mathrm{C}=\mathrm{N}), 1461,1389,1274,1249\left(\mathrm{C}_{\mathrm{Ar}}-\mathrm{O}\right), 1206\left(\mathrm{C}_{\mathrm{Ar}}-\mathrm{O}\right), 1158,1075,968,789,754,738$, 693, 573, 491, 429, $411 \mathrm{~cm}^{-1},{ }^{1} \mathrm{H}$ NMR (400 MHz, DMSO- $\left.d_{6}\right): \delta 13.83(\mathrm{~s}, 1 \mathrm{H}, \mathrm{OH}), 12.59$ (s, $1 \mathrm{H}, \mathrm{OH}), 12.27(\mathrm{~s}, 1 \mathrm{H}, \mathrm{NHCO}), 8.77(\mathrm{~s}, 1 \mathrm{H}, \mathrm{CH}=\mathrm{N}), 8.32\left(\mathrm{~d},{ }^{3} \mathrm{~J}=8.2 \mathrm{~Hz}, 1 \mathrm{H}, \mathrm{H}-8\right), 7.98$ $\left(\mathrm{d},{ }^{3} \mathrm{~J}=8.9 \mathrm{~Hz}, 1 \mathrm{H}, \mathrm{H}-3\right), 7.92\left(\mathrm{~d},{ }^{3} \mathrm{~J}=8.1 \mathrm{~Hz}, 1 \mathrm{H}, \mathrm{H}-5\right), 7.69\left(\mathrm{ddd},{ }^{3} J=6.8 \mathrm{~Hz},{ }^{3} J=6.8 \mathrm{~Hz}\right.$, $\left.{ }^{4} J=1.2 \mathrm{~Hz}, 1 \mathrm{H}, \mathrm{H}-6\right), 7.62\left(\mathrm{~d},{ }^{3} J=7.7 \mathrm{~Hz}, 2 \mathrm{H}, \mathrm{PhH}-2,6\right), 7.60\left(\mathrm{ddd},{ }^{3} J=8.2 \mathrm{~Hz},{ }^{3} J=6.8 \mathrm{~Hz}\right.$, $\left.{ }^{4} J=1.1 \mathrm{~Hz}, 1 \mathrm{H}, \mathrm{H}-7\right), 7.53\left(\mathrm{dd},{ }^{3} J=7.7 \mathrm{~Hz},{ }^{4} J=1.4 \mathrm{~Hz}, 1 \mathrm{H}, \mathrm{ArH}-6\right), 7.49\left(\mathrm{~d},{ }^{3} J=8.9 \mathrm{~Hz}\right.$, H-4), $7.46\left(\mathrm{dd},{ }^{3} J=7.7 \mathrm{~Hz},{ }^{3} J=7.3 \mathrm{~Hz}, 2 \mathrm{H}, \mathrm{PhH}-3,5\right), 7.43\left(\mathrm{dd},{ }^{3} J=7.5 \mathrm{~Hz},{ }^{4} J=1.4 \mathrm{~Hz}, 1 \mathrm{H}\right.$, ArH-4), $7.36\left(\mathrm{t},{ }^{3} J=7.3 \mathrm{~Hz}, 1 \mathrm{H}, \mathrm{PhH}-4\right), 7.07\left(\mathrm{t},{ }^{3} \mathrm{~J}=7.7 \mathrm{~Hz},{ }^{3} J=7.5 \mathrm{~Hz}, 1 \mathrm{H}\right.$, ArH-5) ppm; ${ }^{13} \mathrm{C}$ NMR $\left(100 \mathrm{MHz}, \mathrm{DMSO}-d_{6}\right): \delta 166.71(\mathrm{C}=\mathrm{O}), 160.21(\mathrm{C}), 154.04(\mathrm{C}), 151.45(\mathrm{CH}=\mathrm{N})$, $137.29(\mathrm{C}), 135.99(\mathrm{C}), 132.59(\mathrm{CH}), 130.85(\mathrm{CH}), 129.36(\mathrm{CH}), 129.16(2 \times \mathrm{CH}), 128.89(\mathrm{C})$, $128.01(2 \times \mathrm{CH}), 127.50(\mathrm{CH}), 127.02(\mathrm{CH}), 126.07(\mathrm{CH}), 124.51(\mathrm{C}), 123.03(\mathrm{CH}), 122.18$ $(\mathrm{CH}), 119.59(\mathrm{CH}), 118.08(\mathrm{CH}), 118.01(\mathrm{C}), 105.72(\mathrm{C}) \mathrm{ppm}$; HRMS (TOF, MS, ESI) $\mathrm{m} / \mathrm{z}$ for $\mathrm{C}_{24} \mathrm{H}_{18} \mathrm{~N}_{2} \mathrm{O}_{3}+\mathrm{H}^{+}$: calculated 383.1390; found: 383.1410.

$N^{\prime}$-[(E)-(3,5-di-tert-butyl-2-hydroxy-phenyl)methylidene]-2-(1-hydroxynaphtho) hydrazide monomethanolate $(5 \mathrm{c})$

The general procedure starting from 3,5-di-tert-butyl-salicylic aldehyde (9) $(234 \mathrm{mg}$, $1.0 \mathrm{mmol}$ [108], 1-hydroxy-2-naphthohydrazide (19) (202 mg, $1.0 \mathrm{mmol})$ [109], $\mathrm{CH}_{3} \mathrm{OH}$ $(75 \mathrm{~mL})$, and $\mathrm{AcOH}(100 \mu \mathrm{L})$ was employed with a $2 \mathrm{~h}$ reaction time, decolorization with charcoal and concentration slow by distillation before crystallization to obtain $N^{\prime}-[(E)$ (3,5-di-tert-butyl-2-hydroxy-phenyl)methylidene]-2-(1-hydroksynaphtho)hydrazide (5c) ( $397 \mathrm{mg}, 0.881 \mathrm{mmol}$ ) as yellow needles with $88 \%$ yield crystallized with one molecule of methyl alcohol, which melts at $122-123^{\circ} \mathrm{C}$. Selected FT-IR (ATR): $v_{\max } 3650\left(\mathrm{CH}_{3} \mathrm{OH}\right)$, $3392(\mathrm{O}-\mathrm{H}), 3322(\mathrm{~N}-\mathrm{H}), 3060\left(\mathrm{C}_{\mathrm{Ar}}-\mathrm{H}\right), 1611(\mathrm{C}=\mathrm{O}), 1596(\mathrm{C}=\mathrm{C}), 1584(\mathrm{~N}-\mathrm{H}), 1563(\mathrm{C}=\mathrm{N})$, 1531, 1467, 1390, 1356, 1278, 1250 ( $\left.\mathrm{C}_{\mathrm{Ar}}-\mathrm{O}\right), 1207$ ( $\left.\mathrm{C}_{\mathrm{Ar}}-\mathrm{O}\right), 1173,1027,815,759,709,535,494$, $419 \mathrm{~cm}^{-1} ;{ }^{1} \mathrm{H}$ NMR $\left(400 \mathrm{MHz}, \mathrm{DMSO}-d_{6}\right): \delta 13.85(\mathrm{~s}, 1 \mathrm{H}, \mathrm{O}-\mathrm{H}), 12.50(\mathrm{~s}, 1 \mathrm{H}, \mathrm{NHCO}), 12.24$ $(\mathrm{s}, 1 \mathrm{H}, \mathrm{O}-\mathrm{H}), 8.70(\mathrm{~s}, 1 \mathrm{H}, \mathrm{CH}=\mathrm{N}), 8.32\left(\mathrm{~d},{ }^{3} \mathrm{~J}=8.2 \mathrm{~Hz}, 1 \mathrm{H}, \mathrm{H}-8\right), 7.98\left(\mathrm{~d},{ }^{3} \mathrm{~J}=8.8 \mathrm{~Hz}, 1 \mathrm{H}, \mathrm{H}-3\right)$, $7.92\left(\mathrm{~d},{ }^{3} \mathrm{~J}=8.0 \mathrm{~Hz}, 1 \mathrm{H}, \mathrm{H}-5\right), 7.69\left(\mathrm{dd},{ }^{3} \mathrm{~J}=8.0 \mathrm{~Hz},{ }^{3} \mathrm{~J}=7.2 \mathrm{~Hz}, 1 \mathrm{H}, \mathrm{H}-6\right), 7.60\left(\mathrm{dd},{ }^{3} \mathrm{~J}=8.2 \mathrm{~Hz}\right.$, $\left.{ }^{3} J=7.2 \mathrm{~Hz}, 1 \mathrm{H}, \mathrm{H}-7\right), 7.50\left(\mathrm{~d},{ }^{3} \mathrm{~J}=8.8 \mathrm{~Hz}, 1 \mathrm{H}, \mathrm{H}-4\right), 7.35\left(\mathrm{~d},{ }^{4} \mathrm{~J}=2.0 \mathrm{~Hz}, 1 \mathrm{H}, \mathrm{ArH}-4\right), 7.28$ $\left(\mathrm{d},{ }^{4} \mathrm{~J}=2.0 \mathrm{~Hz}, 1 \mathrm{H}, \mathrm{ArH}-6\right), 4.10\left(\mathrm{~s}, 1 \mathrm{H}, \mathrm{CH}_{3} \mathrm{OH}\right), 3.17$ (s, 3H, $\left.\mathrm{CH}_{3} \mathrm{OH}\right), 1.43(\mathrm{~s}, 9 \mathrm{H}, \mathrm{Ar}-3-$ $t$-Bu), 1.30 (s, 9H, Ar-5-t-Bu) ppm; ${ }^{13} \mathrm{C}$ NMR (100 MHz, DMSO-d $\left.d_{6}\right): \delta 166.59$ (C), 160.14 $(\mathrm{C}=\mathrm{O}), 154.83(\mathrm{C}), 152.72(\mathrm{CH}=\mathrm{N}), 140.52(\mathrm{C}), 135.97(\mathrm{C}), 135.73(\mathrm{C}), 129.34(\mathrm{CH}), 127.51$ $(\mathrm{CH}), 126.08(\mathrm{CH}), 126.01(\mathrm{CH}), 125.97(\mathrm{CH}), 124.53(\mathrm{C}), 123.04(\mathrm{CH}), 122.25(\mathrm{CH}), 118.06$ $(\mathrm{CH}), 116.78(\mathrm{C}), 105.79(\mathrm{C}), 48.52\left(\mathrm{CH}_{3} \mathrm{OH}\right), 34.62(\mathrm{C}), 33.85(\mathrm{C}), 31.22\left(3 \times \mathrm{CH}_{3}-t-\mathrm{Bu}\right)$, $29.23\left(3 \times \mathrm{CH}_{3}-t\right.$-Bu) ppm; HRMS (TOF, MS, ESI) $m / z$ for $\mathrm{C}_{26} \mathrm{H}_{30} \mathrm{~N}_{2} \mathrm{O}_{3}+\mathrm{Na}^{+}$: calculated 441.2149; found: 441.2152 . 


\section{$N^{\prime}$-[(E)-(3-tert-butyl-2-hydroxy-phenyl)methylidene]-2-(1-hydroxynaphtho) hydrazide $(5 \mathrm{~d})$}

The general procedure starting from 3-tert-butyl-salicylic aldehyde (7) $(89 \mathrm{mg}$, $0.50 \mathrm{mmol}$ ) [108], 1-hydroxy-2-naphthohydrazide (19) (101 mg, $0.50 \mathrm{mmol}$ [109], $\mathrm{CH}_{3} \mathrm{OH}$ $(22.5 \mathrm{~mL})$, and $\mathrm{AcOH}(50 \mu \mathrm{L})$ was employed with a $2 \mathrm{~h}$ reaction time, decolorization with charcoal and concentration slow by distillation before crystallization to obtain $N^{\prime}-[(E)$-(3tert-butyl-2-hydroxy-phenyl)methylidene]-2-(1-hydroxynaphtho)hydrazide (5d) (180 mg, $0.497 \mathrm{mmol}$ ) as yellow crystals with $99 \%$ yield, which melts at $220-222{ }^{\circ} \mathrm{C}$. Selected FT-IR (ATR): $v_{\max } 3420(\mathrm{O}-\mathrm{H}), 3275(\mathrm{~N}-\mathrm{H}), 3056\left(\mathrm{C}_{\mathrm{Ar}}-\mathrm{H}\right), 2948\left(\mathrm{CH}_{3}\right), 1623(\mathrm{C}=\mathrm{O}), 1602(\mathrm{~N}-\mathrm{H}$, $\mathrm{C}=\mathrm{C}), 1565(\mathrm{C}=\mathrm{N}), 1389,1358,1279,1252\left(\mathrm{C}_{\mathrm{Ar}} \mathrm{O}\right), 1208\left(\mathrm{C}_{\mathrm{Ar}} \mathrm{O}\right), 1147,807,789,745,495$, $420 \mathrm{~cm}^{-1} ;{ }^{1} \mathrm{H}$ NMR $\left(400 \mathrm{MHz}, \mathrm{DMSO}-d_{6}\right): \delta 13.84(\mathrm{~s}, 1 \mathrm{H}, \mathrm{OH}), 12.51(\mathrm{~s}, 1 \mathrm{H}, \mathrm{NHCO}), 12.41$ $(\mathrm{s}, 1 \mathrm{H}, \mathrm{OH}), 8.70(\mathrm{~s}, 1 \mathrm{H}, \mathrm{CH}=\mathrm{N}), 8.32\left(\mathrm{~d},{ }^{3} \mathrm{~J}=8.3 \mathrm{~Hz}, 1 \mathrm{H}, \mathrm{H}-8\right), 7.98\left(\mathrm{~d},{ }^{3} \mathrm{~J}=8.9 \mathrm{~Hz}, 1 \mathrm{H}, \mathrm{H}-3\right)$, $7.92\left(\mathrm{~d},{ }^{3} \mathrm{~J}=8.1 \mathrm{~Hz}, 1 \mathrm{H}, \mathrm{H}-5\right), 7.69\left(\mathrm{dd},{ }^{3} \mathrm{~J}=8.1 \mathrm{~Hz},{ }^{3} \mathrm{~J}=6.9 \mathrm{~Hz},{ }^{4} J=1.2 \mathrm{~Hz}, 1 \mathrm{H}, \mathrm{H}-6\right), 7.60$ $\left(\mathrm{dd},{ }^{3} \mathrm{~J}=8.3 \mathrm{~Hz},{ }^{3} \mathrm{~J}=6.7 \mathrm{~Hz},{ }^{4} \mathrm{~J}=1.2 \mathrm{~Hz}, 1 \mathrm{H}, \mathrm{H}-7\right), 7.49\left(\mathrm{~d},{ }^{3} \mathrm{~J}=8.9 \mathrm{~Hz}, 1 \mathrm{H}, \mathrm{H}-4\right), 7.34(\mathrm{~d}$, $\left.{ }^{3} J=7.6 \mathrm{~Hz}, 1 \mathrm{H}, \mathrm{ArH}-6\right), 7.33\left(\mathrm{~d},{ }^{3} J=7.8 \mathrm{~Hz}, 1 \mathrm{H}, \mathrm{ArH}-4\right), 6.91\left(\mathrm{dd},{ }^{3} \mathrm{~J}=7.8 \mathrm{~Hz},{ }^{3} J=7.6 \mathrm{~Hz}\right.$, $1 \mathrm{H}, \mathrm{ArH}-5), 1.42$ (s, 9H, $t$-Bu) ppm; ${ }^{13} \mathrm{C}$ NMR (100 MHz, DMSO- $\left.d_{6}\right): \delta 166.61$ (C-1), 160.18 $(\mathrm{C}=\mathrm{O}), 157.05(\mathrm{ArC}-2-\mathrm{OH}), 152.27(\mathrm{CH}=\mathrm{N}), 136.42(\mathrm{C}), 135.98(\mathrm{C}), 129.84(\mathrm{CH}), 129.34(\mathrm{CH})$, $128.90(\mathrm{CH}), 127.50(\mathrm{CH}), 126.07(\mathrm{CH}), 124.53(\mathrm{C}), 123.05(\mathrm{CH}), 122.19(\mathrm{CH}), 118.84(\mathrm{CH})$, $118.07(\mathrm{CH}), 117.45(\mathrm{C}), 105.74(\mathrm{C}), 34.45(\mathrm{C}), 29.16\left(3 \times \mathrm{CH}_{3}\right)$ ppm; HRMS (TOF, MS, ESI) $m / z$ for $\mathrm{C}_{22} \mathrm{H}_{22} \mathrm{~N}_{2} \mathrm{O}_{3}+\mathrm{Na}^{+}$: calculated 385.1523; found: 385.1535 .

\subsection{Reaction Condition and Kinetic Calculations}

Reaction conditions and kinetic assays were performed as reported previously [25]. Briefly, the kinetic measurements were conducted in $\mathrm{pH} 5.3$ at $25^{\circ} \mathrm{C}$. A reaction was carried out in a plastique cuvette with a total capacity of $2.0 \mathrm{~mL}$. It contained $1.5 \mathrm{~mL}$ of a diluted in Mcllvain buffer enzyme (10-50 nM), $0.1 \mathrm{~mL}$ of inhibitor $\left(1 \times 10^{3} \mu \mathrm{M}\right)$, and $0.1 \mathrm{~mL}$ of syringaldazine $(0.5-15 \mu \mathrm{M})$. Hydrazide-hydrazones, sodium azide, and syringaldazine were dissolved in methanol as co-solvent before use. Before reaction, the enzyme was preincubated with an inhibitor for $30 \mathrm{~min}$. The progress of the reaction was measured at $525 \mathrm{~nm}$ (Shimadzu, UV-VIS 1800, Tokyo, Japan) using UVProbe 2.70 software. Each reaction was performed at least in triplicate. The velocity of the syringaldazine conversion was expressed as a change in product concentration in time $(\mu \mathrm{M} / \mathrm{min})$ and calculated from the region of a first-order kinetic using an extinction coefficient $\varepsilon_{0}=65,000 \mathrm{~cm}^{-1}$ [110]. The kinetic parameters for all tested compounds were calculated by using Lineweaver-Burk transformation and the linear least square method in Matlab (The Mathworks, R2019R Version 9.6, academic license) using steady-state kinetics. The goodness of fit was assessed using the coefficient of determination $\left(\mathrm{R}^{2}\right)$, the sum of square errors (SSE), and root mean squared error (RMSE). The following equations were applied for the determination of the competitive Equation (1), non-competitive Equation (2), uncompetitive Equation (3), and mixed Equation (4) types of inhibition [99]. Mixed type of inhibition Equation (4) was determined based the Segel's mathematical model where $K_{\mathrm{I}}$ component corresponds to the competitive component, whereas $\alpha \cdot K_{\mathrm{I}}$ is a non-competitive or uncompetitive component for $\alpha<1$ or $\alpha>1$, respectively. The resulted from inhibition changes in $V_{\max }\left[\mu \mathrm{M} \cdot \min ^{-1}\right]$ and $K_{\mathrm{M}}[\mu \mathrm{M}]$ parameters were expressed as their apparent counterparts $\mathrm{V}_{\text {max,app }}\left[\mu \mathrm{M} \cdot \min ^{-1}\right]$ and $K_{\mathrm{M} \text {,app }}$ $[\mu \mathrm{M}]$. The constant inhibition values $\left(K_{\mathrm{I}}\right)$ were determined by replotting fixed apparent values versus inhibitor concentrations into a linear function (Figures 2 and 3 ).

$$
1 / \mathrm{V}=\left(K_{\mathrm{M}, \mathrm{app}} / \mathrm{V}_{\max }\right) \cdot\left(1 / \mathrm{C}_{\mathrm{s}}\right)+1 / \mathrm{V}_{\max }
$$

where $K_{\mathrm{M}, \text { app }}$ is defined as $K_{\mathrm{M}} \cdot\left(1+\mathrm{I} / K_{\mathrm{I}}\right)$

$$
1 / \mathrm{V}=\left(K_{\mathrm{M}} / \mathrm{V}_{\max , \mathrm{app}}\right) \cdot\left(1 / \mathrm{C}_{\mathrm{s}}\right)+1 / \mathrm{V}_{\max , \mathrm{app}}
$$


where $\mathrm{V}_{\max , a p p}$ is defined as $\left(1+\mathrm{I} / K_{\mathrm{I}}\right) / \mathrm{V}_{\max }$

$$
1 / \mathrm{V}=\left(K_{\mathrm{M}} / \mathrm{V}_{\max }\right) \cdot\left(1 / \mathrm{C}_{\mathrm{s}}\right)+1 / \mathrm{V}_{\max , \mathrm{app}}
$$

where $\mathrm{V}_{\max , \text { app }}$ is defined as $\left(1+\mathrm{I} / K_{\mathrm{I}}\right) / \mathrm{V}_{\max }$ or $1 / K_{\mathrm{M}, \text { app }}=\left(1 / K_{\mathrm{M}}\right) \cdot\left(1+\mathrm{I} / K_{\mathrm{I}}\right)$

$$
1 / \mathrm{V}=\left(K_{\mathrm{M}, \mathrm{app}} / \mathrm{V}_{\max }\right) \cdot\left(1 / \mathrm{C}_{\mathrm{s}}\right)+1 / \mathrm{V}_{\max , \text { app }}
$$

where $K_{\mathrm{M} \text {,app }}$ is defined as $K_{\mathrm{M}} \cdot\left(1+\mathrm{I} / K_{\mathrm{I}}\right)$, and $\mathrm{V}_{\max \text {,app }}$ defined as $\left(1+\mathrm{I} / \alpha \cdot K_{\mathrm{I}}\right) / \mathrm{V}_{\max }$, where $K_{\mathrm{M}}-\mathrm{a}$ Michaelis-Menten constant $[\mu \mathrm{M}], \mathrm{K}_{\mathrm{M} \text {,app }}$-an apparent Michaelis-Menten constant $[\mu \mathrm{M}], \mathrm{V}_{\max }$ - a maximal enzyme velocity $\left[\mu \mathrm{M} \cdot \min ^{-1}\right], \mathrm{V}_{\max , a p p}$-an apparent maximal enzyme velocity $\left[\mu \mathrm{M} \cdot \mathrm{min}^{-1}\right], \mathrm{C}_{\mathrm{s}}$-a substrate (syringaldazine) concentration, Ian inhibitor concentration $[\mu \mathrm{M}], K_{\mathrm{I}}-$ an inhibition constant $[\mu \mathrm{M}], \alpha \cdot K_{\mathrm{I}}$ is a non-competitive or uncompetitive component for $\alpha<1$ or $\alpha>1$ in the mixed type of inhibition, respectively.

\section{Conclusions}

In this work, we aimed to investigate the inhibition activity of hydrazide-hydrazones towards laccase from Trametes versicolor. The hydrazide-hydrazones were synthesized using four salicylic aldehydes of choice and eleven hydrazides to obtain 21 derivatives, of which 20 have not been described in the literature so far. The most active compounds have the constant inhibition in the range of 8 and $25.8 \mu \mathrm{M}$ and present diversified types of inhibition, but none of them interact with the enzyme-substrate complex. Kinetic results revealed that the presence of an arene electron-rich benzoyl fragment containing hydroxy and methoxy group in 3 and 4 positions of the benzene ring is necessary to inhibit laccase activity effectively. Performed for selected derivatives, the structure-activity relationship analysis showed that the slice differences in the built of the inhibitors might reflect the inhibition type. We evaluated the contribution of the selected amino acids from the substrate center with the possibility of changing the type of inhibition. The deep and substrate-like binding is preferred to interact competitively, but the mixed systems with uncommon interactions resulted in lower $K_{\mathrm{I}}$ values. The found hydrazide-hydrazones with the highest activity towards laccase will be the subject of further research on SAR and future application to protect cultivating plans against phytopathogenic fungi [107].

Supplementary Materials: It is available online at https:/ / www.mdpi.com/article/10.3390/ijms222 $212307 /$ s1.

Author Contributions: H.M. and M.G. conceived, designed, performed experiments, and analyzed the data, M.T. performed molecular docking studies, H.M., M.G. and M.T. wrote and reviewed the paper. All authors have read and agreed to the published version of the manuscript.

Funding: This research was funded by the Wroclaw University of Science and Technology (8211104160).

Institutional Review Board Statement: Not applicable.

Informed Consent Statement: Not applicable.

Data Availability Statement: Not applicable.

Acknowledgments: The authors acknowledge the financial support to the Wrocław University of Science and Technology (Subsidiary Funds 8211104160).

Conflicts of Interest: The authors declare no conflict of interest.

\section{References}

1. Witayakran, S.; Ragauskas, A.J. Synthetic Applications of Laccase in Green Chemistry. Adv. Synth. Catal. 2009, 351, 1187-1209. [CrossRef]

2. Sousa, A.; Martins, L.; Robalo, M. Laccases: Versatile Biocatalysts for the Synthesis of Heterocyclic Cores. Molecules 2021, $26,3719$. [CrossRef]

3. Kim, S. Mushroom Ligninolytic Enzymes-Features and Application of Potential Enzymes for Conversion of Lignin into Bio-Based Chemicals and Materials. Appl. Sci. 2021, 11, 6161. [CrossRef] 
4. Ardila-Leal, L.; Poutou-Piñales, R.; Pedroza-Rodríguez, A.; Quevedo-Hidalgo, B. A Brief History of Colour, the Environmental Impact of Synthetic Dyes and Removal by Using Laccases. Molecules 2021, 26, 3813. [CrossRef]

5. Bassanini, I.; Ferrandi, E.; Riva, S.; Monti, D. Biocatalysis with Laccases: An Updated Overview. Catalysts 2020, 11, 26. [CrossRef]

6. Singh, G.; Bhalla, A.; Kaur, P.; Capalash, N.; Sharma, P. Laccase from prokaryotes: A new source for an old enzyme. Rev. Environ. Sci. Bio. Technol. 2011, 10, 309-326. [CrossRef]

7. Asano, T.; Seto, Y.; Hashimoto, K.; Kurushima, H. Mini-review an insect-specific system for terrestrialization: Laccase-mediated cuticle formation. Insect Biochem. Mol. Biol. 2019, 108, 61-70. [CrossRef]

8. Dwivedi, U.N.; Singh, P.; Pandey, V.; Kumar, A. Structure-function relationship among bacterial, fungal and plant laccases. J. Mol. Catal. B Enzym. 2011, 68, 117-128. [CrossRef]

9. Leonowicz, A.; Cho, N.; Luterek, J.; Jarosz-Wilkolazka, A.; Wojtas-Wasilewska, M.; Matuszewska, A.; Hofrichter, M.; Wesenberg, D.; Rogalski, J. Fungal laccase: Properties and activity on lignin. J. Basic Microbiol. 2001, 41, 185-227. [CrossRef]

10. Williamson, P.R. Laccase and melanin in the pathogenesis of Cryptococcus neoformans. Front. Biosci. 1997, 2, e99-e107. [CrossRef]

11. Zhu, X.; Williamson, P.R. Role of laccase in the biology and virulence of Cryptococcus neoformans. FEMS Yeast Res. 2004, 5, 1-10. [CrossRef]

12. Emidio, E.C.P.; Urán, M.E.J.; Silva, L.B.R.; Dias, L.S.; Doprado, M.; Nosanchuk, J.D.; Taborda, C.P. Melanin as a Virulence Factor in Different Species of Genus Paracoccidioides. J. Fungi 2020, 6, 291. [CrossRef]

13. Labois, C.; Stempien, E.; Schneider, J.; Schaeffer-Reiss, C.; Bertsch, C.; Goddard, M.-L.; Chong, J. Comparative Study of Secreted Proteins, Enzymatic Activities of Wood Degradation and Stilbene Metabolization in Grapevine Botryosphaeria Dieback Fungi. J. Fungi 2021, 7, 568. [CrossRef]

14. Degani, O.; Goldblat, Y. Potential Role of Laccases in the Relationship of the Maize Late Wilt Causal Agent, Magnaporthiopsis maydis, and Its Host. J. Fungi 2020, 6, 63. [CrossRef]

15. Favaron, F.; Lucchetta, M.; Odorizzi, S.; Pais da Cunha, A.; Sella, L. The role of grape polyphenols on trans-rescerastrol activity against Botrytis cinerea and of fungal laccase on the solubility of putiative grape PR proteins. J. Plant Pathol. 2009, 91, 579-588.

16. Rigling, D.; Van Alfen, N.K. Regulation of laccase biosynthesis in the plant-pathogenic fungus Cryphonectria parasitica by double-stranded RNA. J. Bacteriol. 1991, 173, 8000-8003. [CrossRef]

17. Quijada-Morin, N.; Garcia, F.; Lambert, K.; Walker, A.-S.; Tiers, L.; Viaud, M.; Sauvage, F.-X.; Hirtz, C.; Saucier, C. Strain effect on extracellular laccase activities fromBotrytis cinerea. Aust. J. Grape Wine Res. 2018, 24, 241-251. [CrossRef]

18. Claus, H. Laccases of Botrytis cinerea. In Biology of Microorganisms on Grapes, in Must and in Wine; Konig, H., Unden, G., Frohlich, Ü., Eds.; Springer: Berlin/Heidelberg, Germany, 2017; pp. 339-356. ISBN 9783319600208.

19. Coman, C.; Moț, A.C.; Gal, E.; Pârvu, M.; Silaghi-Dumitrescu, R. Laccase is upregulated via stress pathways in the phytopathogenic fungus Sclerotinia sclerotiorum. Fungal Biol. 2013, 117, 528-539. [CrossRef]

20. Wahleithner, J.A.; Xu, F.; Brown, K.M.; Brown, S.H.; Golightly, E.J.; Halkier, T.; Kauppinen, S.; Pederson, A.; Schneider, P. The identification and characterization of four laccases from the plant pathogenic fungusRhizoctonia solani. Curr. Genet. 1996, 29, 395-403. [CrossRef]

21. Rogalski, J.; Janusz, G.; Legiec, D.; Shin, S.-J.; Ohga, S. Purification of Extracellular Laccase from Rhizoctonia praticola. J. Fac. Agric. Kyushu Univ. 2011, 56, 1-7. [CrossRef]

22. Peng, Y.; Li, S.J.; Yan, J.; Tang, Y.; Cheng, J.P.; Gao, A.J.; Yao, X.; Ruan, J.J.; Xu, B.L. Research Progress on Phytopathogenic Fungi and Their Role as Biocontrol Agents. Front. Microbiol. 2021, 12, 670135. [CrossRef]

23. Agrios, G. Plant Pathogens and Disease: General Introduction. In Encyclopedia of Microbiology; Elsevier BV: Amsterdam, The Netherlands, 2009; pp. 613-646.

24. Couto, S.; Herrera, L. Inhibitors of Laccases: A Review. Curr. Enzym. Inhib. 2006, 2, 343-352. [CrossRef]

25. Martínez-Sotres, C.; Rutiaga-Quiñones, J.G.; Herrera-Bucio, R.; Gallo, M.; López-Albarrán, P. Molecular docking insights into the inhibition of laccase activity by medicarpin. Wood Sci. Technol. 2015, 49, 857-868. [CrossRef]

26. Dalisay, D.S.; Saludes, J.P.; Molinski, T.F. Ptilomycalin A inhibits laccase and melanization in Cryptococcus neoformans. Bioorganic Med. Chem. 2011, 19, 6654-6657. [CrossRef]

27. Zavarzina, A.; Leontievsky, A.; Golovleva, L.; Trofimov, S. Biotransformation of soil humic acids by blue laccase of Panus tigrinus 8/18: An in vitro study. Soil Biol. Biochem. 2004, 36, 359-369. [CrossRef]

28. Tišma, M.; Molnar, M.; Skarica, M.; Čačić, M.; Zelić, B. Laccase Inhibiting Activity of Some Coumarin Derivatives. Lett. Org. Chem. 2014, 11, 583-589. [CrossRef]

29. Ladd, J.; Butler, J. Inhibition by soil humic acids of native and acetylated proteolytic enzymes. Soil Biol. Biochem. 1971, 3, 157-160. [CrossRef]

30. Krátký, M.; Svrčková, K.; Vu, Q.; Štěpánková, Š.; Vinšová, J. Hydrazones of 4-(Trifluoromethyl)benzohydrazide as New Inhibitors of Acetyl- and Butyrylcholinesterase. Molecules 2021, 26, 989. [CrossRef]

31. Maniak, H.; Talma, M.; Matyja, K.; Trusek, A.; Giurg, M. Synthesis and Structure-Activity Relationship Studies of HydrazideHydrazones as Inhibitors of Laccase from Trametes versicolor. Molecules 2020, 25, 1255. [CrossRef]

32. Popiołek, Ł. The bioactivity of benzenesulfonyl hydrazones: A short review. Biomed. Pharmacother. 2021, 141, 111851. [CrossRef]

33. Sava, A.; Buron, F.; Routier, S.; Panainte, A.; Bibire, N.; Constantin, S.; Lupașcu, F.; Focșa, A.; Profire, L. Design, Synthesis, In Silico and In Vitro Studies for New Nitric Oxide-Releasing Indomethacin Derivatives with 1,3,4-Oxadiazole-2-thiol Scaffold. Int. J. Mol. Sci. 2021, 22, 7079. [CrossRef] [PubMed] 
34. Gan, X.; Hu, D.; Chen, Z.; Wang, Y.; Song, B. Synthesis and antiviral evaluation of novel 1,3,4-oxadiazole/thiadiazole-chalcone conjugates. Bioorganic Med. Chem. Lett. 2017, 27, 4298-4301. [CrossRef]

35. Roztocki, K.; Formalik, F.; Krawczuk, A.; Senkovska, I.; Kuchta, B.; Kaskel, S.; Matoga, D. Collective Breathing in an Eightfold Interpenetrated Metal-Organic Framework: From Mechanistic Understanding towards Threshold Sensing Architectures. Angew. Chem. 2020, 132, 4521-4527. [CrossRef]

36. Hardy, J.G. Metallosupramolecular grid complexes: Towards nanostructured materials with high-tech applications. Chem. Soc. Rev. 2013, 42, 7881-7899. [CrossRef]

37. Gale, P.A.; Busschaert, N.; Haynes, C.J.E.; Karagiannidis, L.E.; Kirby, I.L. Anion receptor chemistry: Highlights from 2011 and 2012. Chem. Soc. Rev. 2014, 43, 205-241. [CrossRef]

38. Gan, C.; Cui, J.; Su, S.; Lin, Q.; Jia, L.; Fan, L.; Huang, Y. Synthesis and antiproliferative activity of some steroidal thiosemicarbazones, semicarbazones and hydrozones. Steroids 2014, 87, 99-107. [CrossRef]

39. Cho, H.J.; Kim, T.; Kim, H.; Song, C. Kim Solid-State Emissive Metallo-Supramolecular Assemblies of Quinoline-Based Acyl Hydrazone. Sensors 2020, 20, 600. [CrossRef]

40. Kobayashi, S.; Mori, Y.; Fossey, J.; Salter, M.M. Catalytic Enantioselective Formation of C-C Bonds by Addition to Imines and Hydrazones: A Ten-Year Update. Chem. Rev. 2011, 111, 2626-2704. [CrossRef]

41. Yang, J.; Huang, L.; Guo, Z.; Ren, W.; Wang, Q. A Cu(II)-benzoyl hydrazone based fluorescent probe for lipopolysaccharides. J. Lumin. 2016, 172, 290-296. [CrossRef]

42. Patil, S.; Pandey, S.; Singh, A.; Radhakrishna, M.; Basu, S. Hydrazide-Hydrazone Small Molecules as AIEgens: Illuminating Mitochondria in Cancer Cells. Chem.-A Eur. J. 2019, 25, 8229-8235. [CrossRef]

43. Nasr, T.; Bondock, S.; Rashed, H.M.; Fayad, W.; Youns, M.; Sakr, T.M. Novel hydrazide-hydrazone and amide substituted coumarin derivatives: Synthesis, cytotoxicity screening, microarray, radiolabeling and in vivo pharmacokinetic studies. Eur. J. Med. Chem. 2018, 151, 723-739. [CrossRef]

44. Wu, B.-X.; Chang, H.-Y.; Liao, Y.-S.; Yeh, M.-Y. Synthesis, photochemical isomerization and photophysical properties of hydrazidehydrazone derivatives. New J. Chem. 2021, 45, 1651-1657. [CrossRef]

45. Tai, X.-S.; Meng, Q.-G.; Liu, L.-L. Synthesis, Crystal Structure, and Cytotoxic Activity of a Novel Eight-Coordinated Dinuclear $\mathrm{Ca}(\mathrm{II})$-Schiff Base Complex. Crystals 2016, 6, 109. [CrossRef]

46. Pilichos, E.; Spanakis, E.; Maniaki, E.-K.; Raptopoulou, C.P.; Psycharis, V.; Turnbull, M.M.; Perlepes, S.P. Diversity of Coordination Modes in a Flexible Ditopic Ligand Containing 2-Pyridyl, Carbonyl and Hydrazone Functionalities: Mononuclear and Dinuclear Cobalt(III) Complexes, and Tetranuclear Copper(II) and Nickel(II) Clusters. Magnetochemistry 2019, 5, 39. [CrossRef]

47. Prakash, G.; Nirmala, M.; Ramachandran, R.; Viswanathamurthi, P.; Malecki, J.G.; Sanmartin, J. Heteroleptic binuclear copper(I) complexes bearing bis(salicylidene)hydrazone ligands: Synthesis, crystal structure and application in catalytic $\mathrm{N}$-alkylation of amines. Polyhedron 2015, 89, 62-69. [CrossRef]

48. Qin, J.; Zhao, S.-S.; Liu, Y.-P.; Man, Z.-W.; Wang, P.; Wang, L.-N.; Xu, Y.; Zhu, H.-L. Preparations, characterization, and biological features of mononuclear $\mathrm{Cu}(\mathrm{II})$ complexes based on hydrazone ligands. Bioorganic Med. Chem. Lett. 2016, 26, 4925-4929. [CrossRef] [PubMed]

49. Affan, A.; Foo, S.W.; Jusoh, I.; Hanapi, S.; Tiekink, E.R. Synthesis, characterization and biological studies of organotin(IV) complexes with hydrazone ligand. Inorg. Chim. Acta 2009, 362, 5031-5037. [CrossRef]

50. Mishra, M.; Tiwari, K.; Singh, A.K.; Singh, V.P. Synthesis, structural and corrosion inhibition studies on Mn(II), Cu(II) and Zn(II) complexes with a Schiff base derived from 2-hydroxypropiophenone. Polyhedron 2014, 77, 57-65. [CrossRef]

51. Chaouiki, A.; Chafiq, M.; Lgaz, H.; Al-Hadeethi, M.R.; Ali, I.H.; Masroor, S.; Chung, I.-M. Green Corrosion Inhibition of Mild Steel by Hydrazone Derivatives in $1.0 \mathrm{M} \mathrm{HCl}$. Coatings 2020, 10, 640. [CrossRef]

52. El-Wahab, H.A. The synthesis and characterization of the hydrazone ligand and its metal complexes and their performance in epoxy formulation surface coatings. Prog. Org. Coat. 2015, 89, 106-113. [CrossRef]

53. Khamaysa, O.M.A.; Selatnia, I.; Lgaz, H.; Sid, A.; Lee, H.-S.; Zeghache, H.; Benahmed, M.; Ali, I.H.; Mosset, P. Hydrazone-based green corrosion inhibitors for API grade mild steel in $\mathrm{HCl}$ : Insights from Electrochemical, XPS, and Computational studies. Colloids Surf. A Physicochem. Eng. Asp. 2021, 626, 127047. [CrossRef]

54. Narang, R.; Narasimhan, B.; Sharma, S. A Review on Biological Activities and Chemical Synthesis of Hydrazide Derivatives. Curr. Med. Chem. 2012, 19, 569-612. [CrossRef] [PubMed]

55. Angelova, V.T.; Vassilev, N.G.; Nikolova-Mladenova, B.; Vitas, J.; Malbaša, R.; Momekov, G.; Djukic, M.; Saso, L. Antiproliferative and antioxidative effects of novel hydrazone derivatives bearing coumarin and chromene moiety. Med. Chem. Res. 2016, 25, 2082-2092. [CrossRef]

56. Onnis, V.; Cocco, M.T.; Fadda, R.; Congiu, C. Synthesis and evaluation of anticancer activity of 2-arylamino-6-trifluoromethyl-3(hydrazonocarbonyl)pyridines. Bioorganic Med. Chem. 2009, 17, 6158-6165. [CrossRef] [PubMed]

57. Vicini, P.; Incerti, M.; Doytchinova, I.; La Colla, P.; Busonera, B.; Loddo, R. Synthesis and antiproliferative activity of benzo[d]isothiazole hydrazones. Eur. J. Med. Chem. 2006, 41, 624-632. [CrossRef]

58. Iliev, I.; Kontrec, D.; Detcheva, R.; Georgieva, M.; Balacheva, A.; Galić, N.; Pajpanova, T. Cancer cell growth inhibition by aroylhydrazone derivatives. Biotechnol. Biotechnol. Equip. 2019, 33, 756-763. [CrossRef]

59. Pham, V.H.; Phan, T.P.D.; Phan, D.C.; Vu, B.D. Synthesis and Bioactivity of Hydrazide-Hydrazones with the 1-AdamantylCarbonyl Moiety. Molecules 2019, 24, 4000. [CrossRef] [PubMed] 
60. El-Sayed, H.A.; Moustafa, A.H.; El-moneim, M.A.; Awad, H.M.; Esmat, A. A new series of hydrazide-hydrazones based 2-oxonicotinonitriles as antimicrobial agents: Design, synthesis and antimicrobial evaluation. Afinidad 2018, 75, 305-310.

61. Reis, D.C.; Despaigne, A.A.R.; Da Silva, J.G.; Silva, N.F.; Vilela, C.F.; Mendes, I.C.; Takahashi, J.; Beraldo, H. Structural Studies and Investigation on the Activity of Imidazole-Derived Thiosemicarbazones and Hydrazones against Crop-Related Fungi. Molecules 2013, 18, 12645-12662. [CrossRef]

62. Popiołek, Ł.; Biernasiuk, A.; Berecka, A.; Gumieniczek, A.; Malm, A.; Wujec, M. New hydrazide-hydrazones of isonicotinic acid: Synthesis, lipophilicity and in vitro antimicrobial screening. Chem. Biol. Drug Des. 2018, 91, 915-923. [CrossRef]

63. Şenkardeş, S.; Kaushik-Basu, N.; Durmaz, I.; Manvar, D.; Basu, A.; Cetin-Atalay, R.; Küçükgüzel, Ş.G. Synthesis of novel diflunisal hydrazide-hydrazones as anti-hepatitis C virus agents and hepatocellular carcinoma inhibitors. Eur. J. Med. Chem. 2016, 108, 301-308. [CrossRef] [PubMed]

64. El-Sabbagh, O.I.; Rady, H. Synthesis of new acridines and hydrazones derived from cyclic $\beta$-diketone for cytotoxic and antiviral evaluation. Eur. J. Med. Chem. 2009, 44, 3680-3686. [CrossRef] [PubMed]

65. Siemann, S.; Evanoff, D.P.; Marrone, L.; Clarke, A.J.; Viswanatha, T.; Dmitrienko, G.I. N-Arylsulfonyl hydrazones as inhibitors of $\mathrm{N}$-arylsulfonyl hydrazones as inhibitors of $\beta$-lactamase. Antimicrob. Agents Chemother. 2002, 46, 2450-2457. [CrossRef]

66. Ravish, I. Synthesis, Pharmacological Evaluation and Molecular Docking of Some Pyrimidinyl Hydrazones. Biochem. Anal. Biochem. 2016, 5, S3. [CrossRef]

67. Can, N.Ö.; Osmaniye, D.; Levent, S.; Sağlık, B.N.; Inci, B.; Ilgın, S.; Özkay, Y.; Kaplancıklı, Z.A. Synthesis of New Hydrazone Derivatives for MAO Enzymes Inhibitory Activity. Molecules 2017, 22, 1381. [CrossRef]

68. Wilde, F.; Lemmerhirt, H.; Emmrich, T.; Bednarski, P.J.; Link, A. Microwave-assisted synthesis and evaluation of acylhydrazones as potential inhibitors of bovine glutathione peroxidase. Mol. Divers. 2014, 18, 307-322. [CrossRef]

69. Khan, M.; Alam, A.; Khan, K.M.; Salar, U.; Chigurupati, S.; Wadood, A.; Ali, F.; Mohammad, J.I.; Riaz, M.; Perveen, S. Flurbiprofen derivatives as novel $\alpha$-amylase inhibitors: Biology-oriented drug synthesis (BIODS), in vitro, and in silico evaluation. Bioorganic Chem. 2018, 81, 157-167. [CrossRef]

70. Taha, M.; Irshad, M.; Imran, S.; Rahim, F.; Selvaraj, M.; Almandil, N.; Mosaddik, A.; Chigurupati, S.; Nawaz, F.; Ismail, N.H.; et al. Thiazole Based Carbohydrazide Derivatives as $\alpha$-Amylase Inhibitor and Their Molecular Docking Study. Heteroat. Chem. 2019, 2019, 7502347. [CrossRef]

71. Atli, Ö.; Özkay, Y. Synthesis and MAO inhibitory activity of novel thiazole-hydrazones. Turk. J. Chem. 2017, 41, 685-699. [CrossRef]

72. Islam, R.; Koizumi, F.; Kodera, Y.; Inoue, K.; Okawara, T.; Masutani, M. Design and synthesis of phenolic hydrazide hydrazones as potent poly(ADP-ribose) glycohydrolase (PARG) inhibitors. Bioorganic Med. Chem. Lett. 2014, 24, 3802-3806. [CrossRef]

73. Wang, G.; Chen, M.; Wang, J.; Peng, Y.; Li, L.; Xie, Z.; Deng, B.; Chen, S.; Li, W. Synthesis, biological evaluation and molecular docking studies of chromone hydrazone derivatives as $\alpha$-glucosidase inhibitors. Bioorganic Med. Chem. Lett. 2017, 27, $2957-2961$. [CrossRef]

74. Mayer, N.; Schweiger, M.; Melcher, M.-C.; Fledelius, C.; Zechner, R.; Zimmermann, R.; Breinbauer, R. Structure-activity studies in the development of a hydrazone based inhibitor of adipose-triglyceride lipase (ATGL). Bioorganic Med. Chem. 2015, 23, 2904-2916. [CrossRef] [PubMed]

75. Rasool, S.; Rehman, A.U.; Abbasi, M.A.; Siddiqui, S.Z.; Gondal, A.S.; Noor, H.A.; Sheral, S.; Ahmad, I. Antibacterial and Enzyme Inhibition Study of Hydrazone Derivatives Bearing 1, 3, 4-Oxadiazole. Pak. J. Chem. 2015, 5, 14-22. [CrossRef]

76. Ahmad, F.; Alam, I.; Huff, S.E.; Pink, J.; Flanagan, S.A.; Shewach, D.; Misko, T.A.; Oleinick, N.L.; Harte, W.E.; Viswanathan, R.; et al. Potent competitive inhibition of human ribonucleotide reductase by a nonnucleoside small molecule. Proc. Natl. Acad. Sci. USA 2017, 114, 8241-8246. [CrossRef] [PubMed]

77. Green, D.A.; Antholine, W.E.; Wong, S.J.; Richardson, D.; Chitambar, C.R. Inhibition of malignant cell growth by 311 , a novel iron chelator of the pyridoxal isonicotinoyl hydrazone class: Effect on the R2 subunit of ribonucleotide reductase. Clin. Cancer Res. 2001, 7, 3574-3579. [PubMed]

78. Hanna, M.L.; Tarasow, T.M.; Perkins, J. Mechanistic differences between in vitro assays for hydrazone-based small molecule inhibitors of anthrax lethal factor. Bioorganic Chem. 2007, 35, 50-58. [CrossRef]

79. Evranos-Aksöz, B.; Yabanoğlu-Çiftçi, S.; Uçar, G.; Yelekçi, K.; Ertan, R. Synthesis of some novel hydrazone and 2-pyrazoline derivatives: Monoamine oxidase inhibitory activities and docking studies. Bioorganic Med. Chem. Lett. 2014, 24, 3278-3284. [CrossRef] [PubMed]

80. Min, D.-H.; Tang, W.-J.; Mrksich, M. Chemical screening by mass spectrometry to identify inhibitors of anthrax lethal factor. Nat. Biotechnol. 2004, 22, 717-723. [CrossRef]

81. Yaropolov, A.I.; Skorobogatko, O.V.; Vartanov, S.S.; Varflomeyev, S.D. Laccase. Appl. Biochem. Biotechnol. 1994, 49, 257-280. [CrossRef]

82. Polak, J.; Jarosz-Wilkolazka, A. Structure/Redox potential relationship of simple organic compounds as potential precursors of dyes for laccase-mediated transformation. Biotechnol. Prog. 2012, 28, 93-102. [CrossRef]

83. Baldrian, P. Fungal laccases-Occurrence and properties. FEMS Microbiol. Rev. 2006, 30, 215-242. [CrossRef]

84. Johannes, C.; Majcherczyk, A. Natural Mediators in the Oxidation of Polycyclic Aromatic Hydrocarbons by Laccase Mediator Systems. Appl. Environ. Microbiol. 2000, 66, 524-528. [CrossRef] 
85. Weglarz-Tomczak, E.; Burda-Grabowska, M.; Giurg, M.; Mucha, A. Identification of methionine aminopeptidase 2 as a molecular target of the organoselenium drug ebselen and its derivatives/analogues: Synthesis, inhibitory activity and molecular modeling study. Bioorganic Med. Chem. Lett. 2016, 26, 5254-5259. [CrossRef] [PubMed]

86. Weglarz-Tomczak, E.; Tomczak, J.M.; Talma, M.; Burda-Grabowska, M.; Giurg, M.; Brul, S. Identification of ebselen and its analogues as potent covalent inhibitors of papain-like protease from SARS-CoV-2. Sci. Rep. 2021, 11, 3640. [CrossRef] [PubMed]

87. Giurg, M.; Gołąb, A.; Suchodolski, J.; Kaleta, R.; Krasowska, A.; Piasecki, E.; Piętka-Ottlik, M. Reaction of bis[(2chlorocarbonyl)phenyl] Diselenide with Phenols, Aminophenols, and Other Amines towards Diphenyl Diselenides with Antimicrobial and Antiviral Properties. Molecules 2017, 22, 974. [CrossRef]

88. Wanat, W.; Talma, M.; Dziuk, B.; Pirat, J.-L.; Kafarski, P. Phosphonic Acid Analogs of Fluorophenylalanines as Inhibitors of Human and Porcine Aminopeptidases N: Validation of the Importance of the Substitution of the Aromatic Ring. Biomolecules 2020, 10, 579. [CrossRef] [PubMed]

89. Węglarz-Tomczak, E.; Talma, M.; Giurg, M.; Westerhoff, H.V.; Janowski, R.; Mucha, A. Neutral metalloaminopeptidases APN and MetAP2 as newly discovered anticancer molecular targets of actinomycin D and its simple analogs. Oncotarget 2018, 9, 29365-29378. [CrossRef]

90. Helios, K.; Maniak, H.; Sowa, M.; Zierkiewicz, W.; Wąsińska-Kałwa, M.; Giurg, M.; Drożdżewski, P.; Trusek-Hołownia, A.; Malik-Gajewska, M.; Krauze, K. Silver(I) complex with 2-amino-4,4 $\alpha$-dihydro-4 $\alpha$,7-dimethyl-3H-phenoxazin-3-one (Phx-1) ligand: Crystal structure, vibrational spectra and biological studies. J. Coord. Chem. 2017, 70, 3471-3487. [CrossRef]

91. Ndikuryayo, F.; Kang, W.-M.; Wu, F.-X.; Yang, W.-C.; Yang, G.-F. Hydrophobicity-oriented drug design (HODD) of new human 4-hydroxyphenylpyruvate dioxygenase inhibitors. Eur. J. Med. Chem. 2019, 166, 22-31. [CrossRef]

92. Nomura, N.; Ishii, R.; Yamamoto, Y.; Kondo, T. Stereoselective Ring-Opening Polymerization of a Racemic Lactide by Using Achiral Salen- and Homosalen-Aluminum Complexes. Chem.-A Eur. J. 2007, 13, 4433-4451. [CrossRef]

93. Casiraghi, G.; Casnati, G.; Puglia, G.; Sartori, G.; Terenghi, G. Selective reactions between phenols and formaldehyde. A novel route to salicylaldehydes. J. Chem. Soc. Perkin Trans. 1 1980, 1, 1862-1865. [CrossRef]

94. Grimster, N.P.; Connelly, S.; Baranczak, A.; Dong, J.; Krasnova, L.B.; Sharpless, K.B.; Powers, E.T.; Wilson, I.A.; Kelly, J.W. Aromatic Sulfonyl Fluorides Covalently Kinetically Stabilize Transthyretin to Prevent Amyloidogenesis while Affording a Fluorescent Conjugate. J. Am. Chem. Soc. 2013, 135, 5656-5668. [CrossRef]

95. Ghatak, S.; Vyas, A.; Misra, S.; O’Brien, P.; Zambre, A.; Fresco, V.M.; Markwald, R.R.; Swamy, K.V.; Afrasiabi, Z.; Choudhury, A.; et al. Novel di-tertiary-butyl phenylhydrazones as dual cyclooxygenase-2/5-lipoxygenase inhibitors: Synthesis, COX/LOX inhibition, molecular modeling, and insights into their cytotoxicities. Bioorganic Med. Chem. Lett. 2014, 24, 317-324. [CrossRef]

96. Peng, X.; Tang, X.; Qin, W.; Dou, W.; Guo, Y.; Zheng, J.; Liu, W.; Wang, D. Aroylhydrazone derivative as fluorescent sensor for highly selective recognition of Zn2+ ions: Syntheses, characterization, crystal structures and spectroscopic properties. Dalton Trans. 2011, 40, 5271-5277. [CrossRef] [PubMed]

97. Drożdżewski, P.; Zasłona, H.; Kubiak, M. Vibrational spectroscopy of 4-hydroxybenzhydrazide and its O,N-deuterated isotopologue accompanied by X-ray structure refinement. Vib. Spectrosc. 2009, 50, 185-192. [CrossRef]

98. Durig, J.R.; Harris, W.C. Infrared and Raman Spectra of Substituted Hydrazines. II Unsymmetrical Dimethyl Hydrazine. J. Chem. Phys. 1969, 51, 4457-4468. [CrossRef]

99. Segel, I.H. Enzyme Kinetics: Behavior and Analysis of Rapid Equilibrium and Steady-State Enzyme Systems; A Wiley-Interscience publication; Wiley: Hoboken, NJ, USA, 1993; ISBN 978-0-471-30309-1.

100. Pierpoint, W.S. The natural history of salicylic acid Plant product and mammalian medicine. Interdiscip. Sci. Rev. 1997, 22, 45-52. [CrossRef]

101. Cui, Z.; Ito, J.; Dohi, H.; Amemiya, Y.; Nishida, Y. Molecular Design and Synthesis of Novel Salicyl Glycoconjugates as Elicitors against Plant Diseases. PLoS ONE 2014, 9, e108338. [CrossRef]

102. Faize, L.; Faize, M. Functional Analogues of Salicylic Acid and Their Use in Crop Protection. Agronomy 2018, 8, 5. [CrossRef]

103. Sýs, M.; Metelka, R.; Frangu, A.; Vytřas, K.; Arbneshi, T. Electrochemical Study of Trametes Versicolor Laccase Compatibility to Different Polyphenolic Substrates. Chemosensors 2017, 5, 9. [CrossRef]

104. Polak, J.; Jarosz-Wilkołazka, A. Whole-cell fungal transformation of precursors into dyes. Microb. Cell Factories 2010, 9, 51. [CrossRef]

105. Arora, D.; Sandhu, D. Laccase production and wood degradation by a white-rot fungus Daedalea flavida. Enzym. Microb. Technol. 1985, 7, 405-408. [CrossRef]

106. Cañas, A.; Camarero, S. Laccases and their natural mediators: Biotechnological tools for sustainable eco-friendly processes. Biotechnol. Adv. 2010, 28, 694-705. [CrossRef]

107. Maniak, H.; Witkowska, D.; Giurg, M. Zastosowanie Hydrazydu Kwasu 4-Hydroksybenzoesowego Oraz Zastosowanie Hydrazydo-Hydrazonów Pochodnych Kwasu 4-Hydroksybenzoesowego Aldehydów Zawierających Fragment Aromatyczny. Polska Patent A1 238660, 20 September 2021.

108. Skarżewski, J.; Ostrycharz, E.; Siedlecka, R.; Zielińska-Błajet, M.; Pisarski, B. Substituted N-Salicylidene $\beta$-Aminoalcohols: Preparation and use as Chiral Ligands in Enantioselective Sulfoxidation and Conjugate Addition. J. Chem. Res. 2001, 2001, 263-264. [CrossRef]

109. White, E.H.; Bursey, M.M.; Roswell, D.F.; Hill, J.H.M. Chemiluminescence of some monoacylhydrazides. J. Org. Chem. 1967, 32, 1198-1202. [CrossRef] [PubMed]

110. Leonowicz, A.; Grzywnowicz, K. Quantitative estimation of laccase forms in some white-rot fungi using syringaldazine as a substrate. Enzym. Microb. Technol. 1981, 3, 55-58. [CrossRef] 